UNIVERSIDADE DE SÃO PAULO
ESCOLA DE ENFERMAGEM DE RIBEIRÃO PRETO

RENATA ANTUNES DE FIGUEIREDO LEITE

\title{
Direito à informação em saúde: análise do conhecimento do paciente acerca de seus direitos
}




\section{RENATA ANTUNES DE FIGUEIREDO LEITE}

\section{Direito à informação em saúde: análise do conhecimento do paciente acerca de seus direitos}

Dissertação apresentada à Escola de Enfermagem de Ribeirão Preto da Universidade de São Paulo, para obtenção do título Mestre em Ciências, Programa Enfermagem Psiquiátrica. Linha de Pesquisa: Estudos sobre a Conduta, a Ética e a Produção do Saber em Saúde.

Orientador: Profạ. Drạ. Carla Aparecida Arena Ventura

Ribeirão Preto

2010 
Autorizo a reprodução e divulgação total ou parcial deste trabalho, por qualquer meio convencional ou eletrônico, para fins de estudo e pesquisa, desde que citada a fonte.

\section{FICHA CATALOGRÁFICA}

Leite, Renata Antunes de Figueiredo

Direito à informação em saúde: análise do conhecimento do paciente acerca de seus direitos / Renata Antunes de Figueiredo Leite ; Orientadora Carla Aparecida Arena Ventura. -- Ribeirão Preto, 2010. 118 f. : il. ; $30 \mathrm{~cm}$.

Dissertação (Mestrado) -- Escola de Enfermagem de Ribeirão Preto - Universidade de São Paulo, 2010.

1. Direito à informação. 2. Direitos do paciente. 3. Acesso à informação. 4. Informação em saúde. 5. Direito à saúde. 
LEITE, Renata Antunes de Figueiredo

Direito à informação em saúde: análise do conhecimento do paciente acerca de seus direitos

Dissertação apresentada à Escola de Enfermagem de Ribeirão Preto da Universidade de São Paulo, para obtenção do título Mestre em Ciências, Programa Enfermagem Psiquiátrica.

Aprovado em $\quad$.......................

Banca Examinadora

Prof. Dr.

Instituição:

Assinatura

Prof. Dr.

Instituição:

Assinatura

Prof. Dr.

Instituição:

Assinatura 


\section{DEDICATÓRIA}

Ao meu filho Enzo, infinita alegria em minha vida e melhor parte de mim.

Ao meu amor José Carlos, pelo incentivo constante, paciência e companheirismo neste longo percurso.

Ao meu pai Renato por valorizar sempre a educação e valores ético-morais, me ensinando a ser uma pessoa cada vez melhor.

À minha mãe Raquel pelo amor e humanidade imensuráveis, apoio em todos os momentos da minha vida.

Aos meus irmãos tão queridos, Rúbia e Renan por tudo que significam para $\operatorname{mim}$.

Aos meus avós, que mesmo de longe, acreditam e torcem por mim. 


\section{AGRADECIMENTOS}

À Prof ${ }^{a}$ Dr ${ }^{\text {a }}$ Carla Aparecida Arena Ventura, que me ensinou tanto nesses anos de convivência, pela disponibilidade, dedicação e competência.

À Prof ${ }^{a}$ Dr ${ }^{a}$ Silvia Rita Marin da Silva Canini pelo carinho e incentivo.

À Prof $^{\mathrm{a}} \operatorname{Dr}^{\mathrm{a}}$ Maria Cristiane Barbosa Galvão, pela amizade e valorosas contribuições para que essa pesquisa se concretizasse.

À $\operatorname{Prof}^{\mathrm{a}} \operatorname{Dr}^{\mathrm{a}}$ Cléa Regina O. Ribeiro, pela atenção, simpatia e valiosas sugestões no decorrer da pesquisa.

À Emanuele S. Brito, por tantas vezes me ouvir, pela ajuda na pesquisa e imensa amizade.

À Tayana Xavier, Marília Pilotto e Janaína Santos, pela amizade e momentos vivenciados ao longo do curso de mestrado.

À Escola de Enfermagem de Ribeirão Preto pela oportunidade de realizar essa pesquisa.

Aos funcionários da Pós-graduação e do departamento de Enfermagem Psiquiátrica pela simpatia e prontidão nos esclarecimentos necessários.

Aos amigos da Biblioteca Central de Ribeirão Preto pelo apoio e amizade.

Aos sujeitos participantes da pesquisa meu respeito e consideração. 


\section{RESUMO}

LEITE, R. A. F. Direito à informação em saúde: análise do conhecimento do paciente acerca de seus direitos. 2010. 118 f. Dissertação (Mestrado) - Escola de Enfermagem de Ribeirão Preto, Universidade de São Paulo, Ribeirão Preto, 2010.

O direito à informação em saúde é um direito que se legitima a partir da informação mediada pelo profissional de saúde, permitindo com que o paciente se empodere desta informação, com a possibilidade de gerar conhecimento e, conseqüentemente, facilitar o exercício de sua cidadania. Esta pesquisa qualitativa de caráter exploratório, com orientação analítico-descritiva, apresentou como objetivo identificar o conhecimento de usuários do setor de Clínica Médica de uma Unidade Básica de Saúde (UBDS) de Ribeirão Preto sobre o seu direito à informação especificado no art. $2^{\circ}$, incisos VI, VII, VIII, e XI da Lei Estadual 10.241/1999: direito a informações claras e objetivas sobre diagnósticos, exames e quaisquer procedimentos realizados pela equipe de saúde, direito de consentir ou recusar procedimentos, direito ao acesso ao seu prontuário médico em caso de necessidade e, por fim, direito a receber receitas médicas legíveis, com assinatura e registro do médico. Utilizou-se para a coleta de dados de entrevista semi-estruturada e a análise dos dados foi realizada a partir da análise de conteúdo. As entrevistas foram realizadas logo após a consulta médica, com 22 usuários de uma UBDS, na tentativa de coletar os dados durante 0 ato reflexivo do paciente sobre 0 momento vivido recentemente. Os resultados demonstram que, apesar do estudo ter apontado lacunas na comunicação entre os profissionais de saúde e os usuários do serviço, as necessidades informacionais dos usuários quanto à diagnóstico, exames, medicamentos, riscos e benefícios do tratamento estão sendo supridas parcialmente, o que denota o início do estabelecimento de relações democráticas entre profissional de saúde e paciente. Em relação ao consentimento esclarecido do usuário, pequeno número dos entrevistados foram consultados se consentiam com os procedimentos e tratamentos propostos, contudo, nenhum usuário teve acesso físico ao documento. Sobre o acesso ao prontuário, este direito não se concretizou nesta pesquisa, já que todos os respondentes nunca vivenciaram este acesso, e a maioria dos entrevistados desconheciam este direito. No que diz respeito ao acesso legível às receitas médicas, poucos disseram entender as prescrições, criticando as letras dos médicos. Algumas dificuldades foram relatadas em relação ao acesso a informações, quais sejam: o desequilíbrio nas relações de poder, a falta de acesso a informações verdadeiras e de qualidade sobre sua saúde, as dificuldades na relação interpessoal com o paciente em virtude da rapidez nos atendimentos, problemas para a concretização do cuidado humanizado à saúde, a dificuldade de exercer o direito de escolha do paciente quanto ao profissional que irá atendê-lo e o excesso de burocracia no sistema. Facilidades em relação ao acesso foram evidenciadas já que houve um grande índice de satisfação dentre pacientes que são usuários efetivos do SUS. Outra 
facilidade foi confirmada já que a grande maioria dos entrevistados reconhece os medicamentos genéricos e apontam que os recebem na própria UBDS. Conclui-se assim que, apesar das lacunas e desafios existentes, o estudo apontou indícios e possibilidades de mudança para a construção conjunta de relações mais democráticas, em que o usuário, como sujeito, exerce direitos, mas também tem consciência de suas obrigações como cidadão, especialmente no que diz respeito à sua relação com o profissional e o serviço de saúde.

Palavras-chave: Direito à informação. Direitos do paciente. Acesso à informação. Informação em saúde. Direito à saúde. 


\section{ABSTRACT}

LEITE, R. A. F. Right to health information: analysis of patients' knowledge concerning their rights. 2010. 118 f. Dissertação (Mestrado) - Escola de Enfermagem de Ribeirão Preto, Universidade de São Paulo, Ribeirão Preto, 2010.

The right to health information is legitimized based on information mediated by health professionals, who empower patients with this information, which in turn permits the generation of knowledge and, consequently, facilitates the exercise of citizenship. This qualitative and exploratory study with an analyticaldescriptive approach investigates the knowledge of users from the medical clinic of a Basic Health Unit (BHU) in Ribeirão Preto, SP, Brazil concerning their right to information provided in Article 2, Items VI, VII, VIII, and XI of State Law 10.241/1999: the right to clear and objective information about diagnoses, exams and any procedures performed by the health team; the right to consent or refuse procedures; the right to access medical records in case of need; and finally, the right to receive legible medical prescriptions with the physician's signature and registration. A semi-structured interview was used to collect data, analyzed via content analysis. Interviews were carried out right after medical consultations with 22 users of a $\mathrm{BHU}$ in an attempt to collect data through the reflections of patients concerning their recent experience. Even though the study evidenced that there are gaps in the communication between health professionals and users, results revealed that the users' information needs concerning diagnosis, exams, medication, risks and benefits of treatment are partially met, which shows that democratic relationships between health professionals and patients are being established. In regard to the users' informed consent, a small number of users were asked to consent to the proposed procedures and treatments, though, no user had physical access to any form. Access to medical records was not evidenced in this study since none of the respondents ever had such access and most of them were unaware of this right. Concerning legible medical prescription, few reported understanding their prescriptions; physicians' handwriting was criticized. Some difficulties were reported in relation to access to information as follows: unbalanced power relations, lack of access to truthful and quality information concerning users' health, difficulties in patients' interpersonal relationships due to the rapidity with which consultations are performed, difficulties in the concretization of humanized health care, difficulty in exercising their right of choice in relation to the professional who will provide care and the system's excessive bureaucracy. Facilities in relation to access were evidenced since a high level of satisfaction was apparent among patients, the effective users of SUS. Another facility was confirmed since most of the respondents acknowledged generic medications and report receiving them in the BHU itself. The conclusion is that despite existent gaps and challenges, the findings indicate that there are possibilities to 
jointly construct more democratic relationships in which users, as subjects, exert their rights but are also aware of their obligations as citizens, especially in regard to their relationship with professionals and the health service.

Key words: Right to Information. Patients' Rights. Access to information. Health Information. Right to Health. 


\section{RESUMEN}

LEITE, R. A. F. Derecho a la información de salud: análisis del conocimiento de los pacientes sobre sus derechos. 2010. 118 f. Dissertação (Mestrado) Escola de Enfermagem de Ribeirão Preto, Universidade de São Paulo, Ribeirão Preto, 2010.

El derecho a la información en salud es un derecho que se legitima a partir de la información mediada por profesionales de salud, permitiendo al paciente se empoderar de esta información con la posibilidad de generar conocimiento y, en consecuencia, facilitar el ejercicio de su cidadanía. Este estudio cualitativo exploratorio con orientación descriptiva y analítica, presenta como objetivo identificar el conocimiento de los usuarios del sector de Medicina Clínica de una Unidad Básica de Salud (UBDS) de Ribeirão Preto sobre su derecho a la información especificado en el art. 2, VI, VII, VIII y XI de la Ley Estadual 10.241/1999: derecho a una información clara y objetiva sobre el diagnóstico, examenes y procedimientos realizados por el equipo de salud, derecho a consentir o rechazar los procedimientos, derecho de acceso a su histórico médico si fuera necesario y, por último, el derecho a recibir recetas legibles, con firma y registro del médico. Se utilizó para recolectar datos de entrevistas semi-estructuradas y el análisis de datos se realizó a partir del análisis de contenido. Las entrevistas se llevaron a cabo poco después de la consulta médica, con 22 usuarios en un UBDS en un intento de recoger datos durante el acto de reflexión sobre un momento experimentado recientemente. Los resultados muestran que aunque el estudio ha señalado ciertas deficiencias en la comunicación entre profesionales de salud y usuarios de los servicios, las necesidades de información de los usuarios sobre el diagnóstico, exámenes, medicamentos, riesgos y beneficios del tratamiento se están cumpliendo en parte, lo que denota el principio del establecimiento de relaciones democráticas entre el profesional de salud y el paciente. En cuanto al consentimiento informado del usuario, un pequeño número de participantes fueron consultados y dieron su consentimiento a los procedimientos y tratamientos que se ofrecen, sin embargo, acceso físico al documento. En cuanto al acceso a los históricos de los pacientes, este derecho no se ha realizado en esta investigación, ya que todos los encuestados nunca habían experimentado tal acceso, y la mayoría de los encuestados desconocen este derecho. En cuanto al acceso a las recetas legibles, pocos dijeron que comprendían las prescripciones, criticando la redacción de los médicos. Algunas dificultades se registraron en relación con el acceso a la información, a saber: el desequilibrio en las relaciones de poder, la falta de acceso a información precisa y de calidad sobre su salud, dificultades en las relaciones interpersonales con los pacientes debido a la rapidez de las sesiones, problemas para la concretización de la humanización en salud, dificultades para ejercer el derecho del paciente elegir el profesional y la excesiva burocracia del sistema. Fueron encontradas facilidades en relación con el acceso con una alta tasa de satisfacción entre los pacientes que son usuarios efectivos del SUS. Otra facilidad fue confirmada como la gran mayoría 
de los encuestados reconocen los medicamentos genéricos y apuntan que los reciben en la propia UBDS. Se concluye que, a pesar de las deficiencias y los desafíos existentes, el estudio encontró evidencia de cambios y posibilidades de construcción conjunta de relaciones más democráticas en las que el usuario, como sujeto, tiene derechos, pero también es consciente de sus obligaciones como ciudadano, especialmente con respecto a su relación con el profesional y el servicio de salud.

Palabras clave: Derecho a la información. Derechos del paciente. Acceso a la información. Información en salud. Derecho a la salud. 


\section{LISTA DE QUADROS}

Quadro 1 - Inter-relação entre os objetivos e as perguntas de pesquisa. .......51

Quadro 2 - Categorias e subcategorias resultantes da sistematização...........53 


\section{LISTA DE TABELAS}

Tabela 1 - Características dos usuários entrevistados segundo idade, sexo, estado civil, escolaridade, profissão, renda e utilização do serviço. .56

Tabela 2 - Recebimento de informações sobre diagnóstico 58

Tabela 3 - Recebimento de informações sobre exames 60

Tabela 4 - Recebimento de informações sobre medicamentos. 62 Tabela 5 - Recebimento de informações sobre riscos e benefícios do tratamento. 64

Tabela 6 - Consentimento esclarecido do usuário quanto à procedimentos relacionados à sua saúde 67

Tabela 7 - Acesso ao prontuário. 70

Tabela 8 - Conhecimento sobre possível acesso ao prontuário. 71

Tabela 9 - Acesso às receitas legíveis pelo paciente. 74 


\section{LISTA DE ABREVIATURAS E SIGLAS}

AIS - Ações Integradas da Saúde

CONASS - Conselho Nacional de Secretários de Saúde

CONASP - Conselho Consultivo de Administração da Saúde Previdenciária

CRFB/1988 - Constituição da República Federativa Brasileira de 1988

INPS - Instituto Nacional de Previdência Social

INAMPS - Instituto Nacional de Assistência Médica da Previdência Social

OMS - Organização Mundial da Saúde

ONU - Organização das Nações Unidas

RENAME - Relação Nacional de Medicamentos Essenciais

SUDS - Sistema Único Descentralizado de Saúde

SUS - Sistema Único de Saúde 


\section{SUMÁRIO}

RESUMO

ABSTRACT

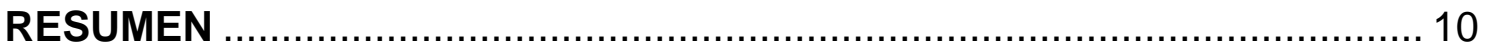

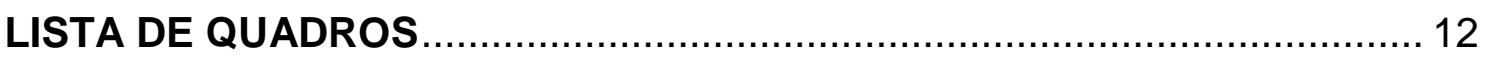

LISTA DE TABELAS

LISTA DE ABREVIATURAS E SIGLAS ................................................. 14

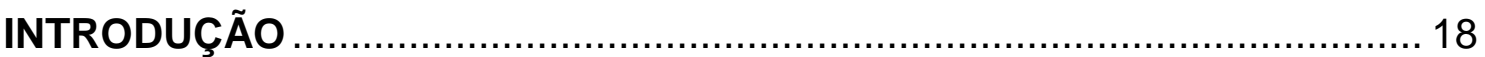

10 DIREITO HUMANO À SAÚDE:

DO DIREITO INTERNACIONAL À LEGISLAÇÃO BRASILEIRA ................... 22

1.1 Direitos humanos e direitos fundamentais ................................... 23

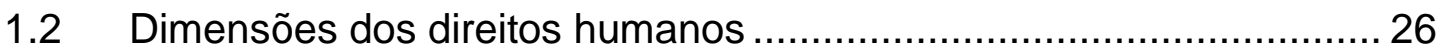

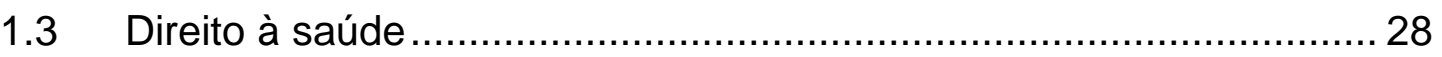

20 DIREITO FUNDAMENTAL À INFORMAÇÃO EM SAÚDE........................ 37

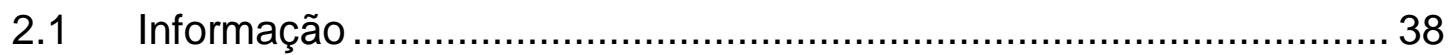

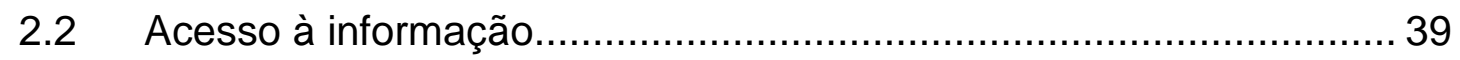

2.3 A mediação e o empoderamento da informação pelo paciente .......... 41 


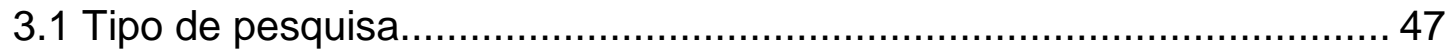

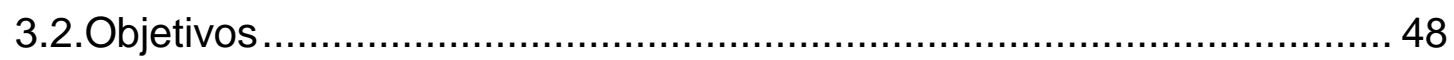

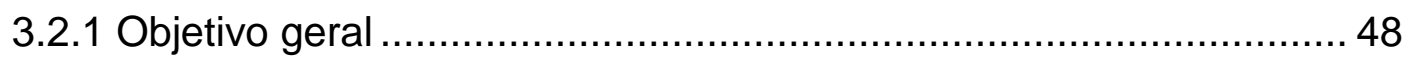

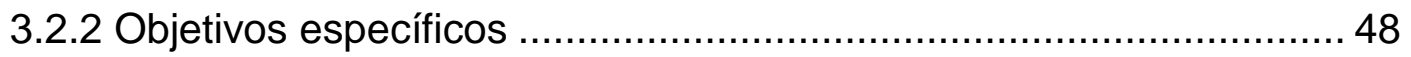

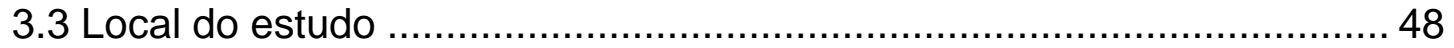

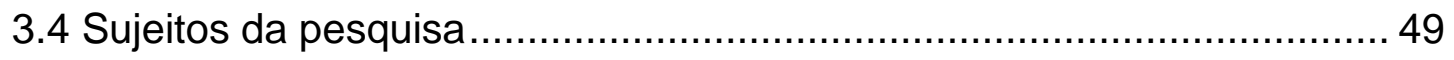

3.5 Procedimento de coleta dos dados .................................................... 49

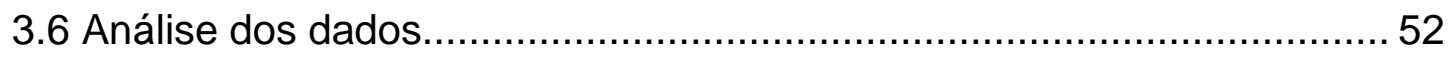

\section{O USUÁRIO DO SUS E O CONHECIMENTO SOBRE O SEU DIREITO À}

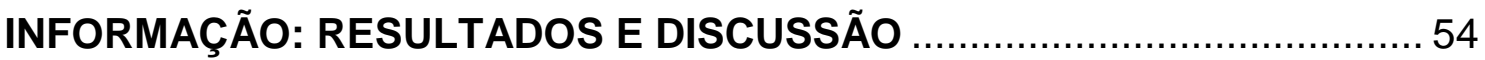

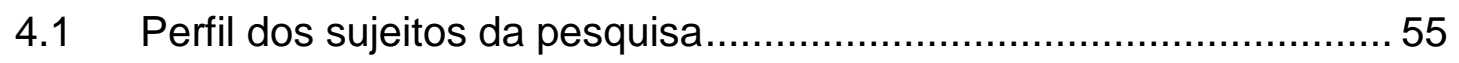

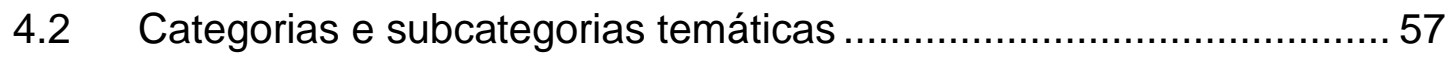

4.2.1 Acesso à informação ……….................................................... 57

4.2.1.1 Acesso à informação sobre diagnóstico .............................. 58

4.2.1.2 Acesso à informação sobre exames.................................... 60

4.2.1.3 Acesso à informação sobre medicamentos ......................... 62

4.2.1.4 Acesso à informação sobre os riscos e benefícios do

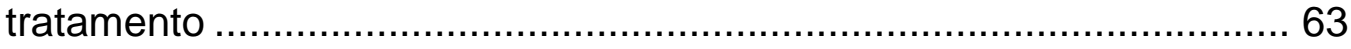

4.2.2 Consentimento esclarecido do usuário ....................................... 66

4.2.3 Acesso ao prontuário ............................................................. 70

4.2.3.1 Conhecimento sobre possível acesso ao prontuário ............ 71 
4.2.4 Receitas médicas ilegíveis................................................... 74

4.2.4.1 Especificidades em relação às prescrições .......................... 76

4.2.5 Desequilíbrio nas relações de poder ........................................... 79

4.2.5.1 Diferenças no poder de posição .......................................... 79

4.2.5.2 Diferenças no poder de especialização .............................. 81

4.2.6 Sentimentos vivenciados ao receber informações ....................... 82

4.2.6.1 Satisfação ao receber as informações................................. 82

4.2.6.2 Insatisfação por não receber informações ............................ 83

4.2.6.3 Falta de acesso a informações verdadeiras ........................ 85

4.2.6.4 Problemas na concretização do cuidado humanizado......... 86

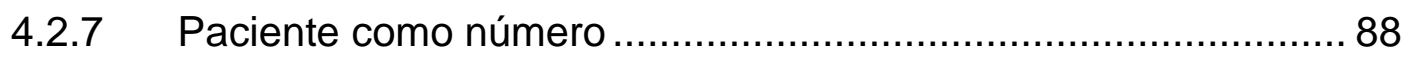

4.2.7.1 Dificuldades na relação interpessoal com o paciente devido à

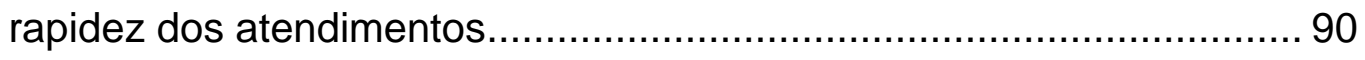

4.2.8 Dificuldade de exercer o direito de escolha do profissional da

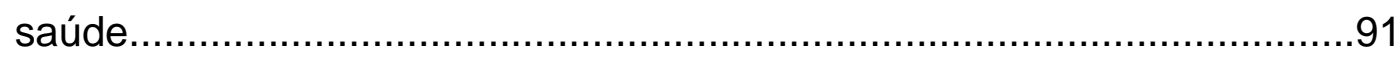

4.2.9 Excesso de burocracia no atendimento ……............................ 92

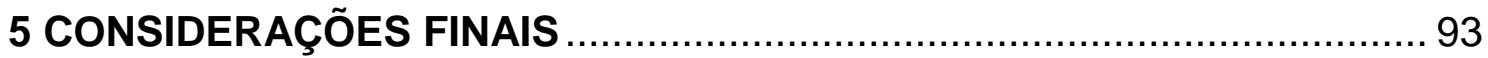

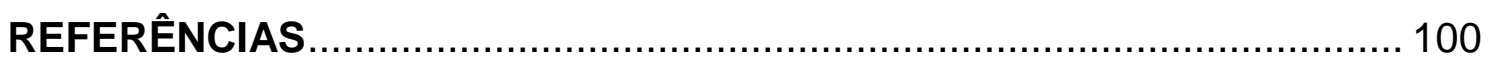

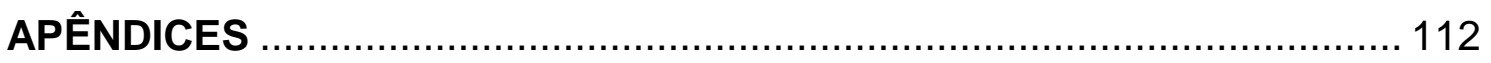

ANEXOS 
$O$ acesso à informação, juntamente com outros direitos e garantias fundamentais, é um direito reconhecido pela Constituição da República Federativa do Brasil de 1988 (CRFB/1988) em seu art. 5, XIV, em que "é assegurado a todos o acesso à informação e resguardado o sigilo da fonte, quando necessário ao exercício profissional", garantindo ao cidadão o direito e o acesso a informações. Em relação ao direito à informação em saúde, especificamente ao direito à informação do paciente, não é diferente. A Portaria do Ministério da Saúde oㅜ 1286 de 26 de outubro de 1993 art. 8o e № 74, a Lei Estadual o 10.241 de 1999, art. 2o e a Carta dos direitos dos usuários da saúde publicada pelo Ministério da Saúde em 2006, dispõem sobre os direitos dos usuários, inclusive sobre a sua informação, em parágrafos específicos.

Contudo, apesar de garantidos os direitos constitucionais e a consagração dos direitos humanos e universais, observa-se ainda grande lacuna entre a lei escrita e o cotidiano dos serviços de saúde (GOMES; FRAGA, 2001).

Os direitos dos usuários normalmente são desconhecidos ou não são informados, o que acarreta perda de informações valiosas a respeito da sua saúde, além de desrespeitar o direito à autonomia de decidir questões relacionadas à sua saúde (BARROS, 2000; FORTES, 1996).

Nesse contexto, este trabalho apresenta como objetivo geral identificar o conhecimento de usuários do Sistema Único de Saúde (SUS) sobre o seu direito à informação contido no art. 2º, incisos VI, VII, VIII, e XI da Lei Estadual 10.241/1999, que trata dos direitos do usuário, quais sejam: direito a informações claras e objetivas sobre diagnósticos, exames e quaisquer procedimentos realizados pela equipe de saúde, direito de consentir ou recusar procedimentos, direito ao acesso ao seu prontuário médico em caso de necessidade e, por fim, direito a receber receitas médicas legíveis, com assinatura e registro do médico.

Além disso, o trabalho objetiva, mais especificamente, identificar as dificuldades e facilidades observadas pelos usuários da Unidade Básica de Saúde, do setor de Clínica Médica, quanto ao acesso à informação relacionada à sua saúde, bem como compreender a importância atribuída por eles ao acesso à essa informação. 
O direito à informação em saúde é tratado sob o prisma do usuário, da informação que a pessoa recebe do "cuidador", seja ele o médico, o enfermeiro, o auxiliar de enfermagem ou qualquer outro membro da equipe de saúde.

Dessa forma, inicialmente é importante esclarecer a terminologia utilizada no trabalho, já que no decorrer da pesquisa, tanto o termo paciente, como o termo usuário são mencionados. Apesar da palavra "paciente" trazer implícita a idéia de passividade e de posição hierarquicamente inferior a do profissional de saúde, este termo não foi totalmente abandonado, uma vez que está inserido na legislação estudada e ainda é universalmente utilizado. Nesse sentido, o termo usuário é utilizado mais especificamente quando dirigido ao contexto institucional, assim como para caracterizar uma visão do paciente como sujeito ativo, participante e autônomo com relação à sua saúde (SOAR FILHO, 1998).

O estudo se insere na linha de pesquisa "Estudos sobre a conduta, a ética e a produção do saber em saúde", do Programa de Pós-graduação em Enfermagem Psiquiátrica, da Escola de Enfermagem de Ribeirão Preto, Universidade de São Paulo.

O interesse em trabalhar com a temática informação em saúde advém de conhecimentos prévios adquiridos na graduação em Ciências da Informação e da Documentação e por ter tido a oportunidade de conhecer um pouco mais do campo da saúde na ênfase "informação em saúde", cursada no último ano de graduação.

A pesquisa se justifica pela carência de estudos realizados na área enfocando o conhecimento dos usuários sobre seu direito à informação, até o momento, como também por trabalhar a interdisciplinaridade entre três campos do conhecimento, quais sejam, a Ciência da Informação, Direito e Saúde. Nessa perspectiva, a interdisciplinaridade "traduz-se por uma colaboração entre diversas disciplinas, que leva a interações, isto é, uma certa reciprocidade nas trocas, de modo que haja, em suma, enriquecimento mútuo" (LE COADIC, 2004, p. 20).

A Ciência da Informação tem como objeto de estudo a interdisciplinaridade com outros campos do conhecimento, e, desse modo, tratar a informação em saúde na perspectiva dos direitos do paciente agrega a ciência da informação, a saúde e o direito, campos do conhecimento distintos, porém, que se entrelaçam neste trabalho. 
Visando alcançar os objetivos propostos, o estudo foi dividido em quatro capítulos.

O primeiro capítulo introduz o direito humano à saúde, enfatizando conceitos de direitos humanos, direitos fundamentais e as dimensões dos direitos humanos. Em seguida, apresenta a legislação brasileira em relação ao direito à saúde, inserindo a incorporação constitucional deste direito e sua evolução até chegar à instituição do Sistema Único de Saúde (SUS).

No segundo capítulo enfatiza-se o direito fundamental à informação em saúde com base no conceito de informação e o direito e acesso à informação, seja físico ou cognitivo. Ressalta-se a necessidade de um mediador da informação, conceituando também a mediação da informação e o papel do mediador nesse processo de geração do conhecimento. Um outro ponto ressaltado nesse capítulo são as relações de poder estabelecidas entre o profissional de saúde e o usuário e a informação como meio de empoderamento do paciente.

No capítulo três são apresentados o tipo de pesquisa, os objetivos, o local de estudo, os sujeitos da pesquisa, o procedimento de coleta de dados e a análise dos dados.

No capítulo quatro são descritos os resultados e discussão a partir das falas dos entrevistados e com fundamento no referencial teórico, considerando os eixos norteadores da pesquisa.

Por fim, no quinto capítulo ou considerações finais são salientadas as contribuições e limitações do estudo. 
10 DIREITO HUMANO À SAÚDE: DO DIREITO INTERNACIONAL À LEGISLAÇÃO BRASILEIRA 


\title{
1.1 Direitos humanos e direitos fundamentais
}

O direito pode ser compreendido como "um fenômeno histórico-cultural, realidade ordenada, ou ordenação normativa da conduta segundo uma conexão de sentido" (SILVA, 2005, p. 33).

Nessa perspectiva, Cury (2005, p. 1) conceitua:

\begin{abstract}
Direitos do homem - expressão mais utilizada na doutrina jusnaturalista contratualista dos séculos XVII a XIX (Locke, Hobbes, Rousseau e Kant). Diz respeito ao direito natural e aos direitos de liberdade dele recorrentes; Direitos humanos - expressão utilizada em relação aos direitos e liberdades previstos em tratados internacionais. É um termo internacionalista dos direitos fundamentais.

Direitos fundamentais - em sentido estrito, podem ser conceituados como o conjunto de normas que cuidam dos direitos e liberdades garantidos institucionalmente pelo direito positivo de determinado Estado; devem sua denominação ao caráter básico e fundamentador de toda ordem jurídica, com limitação espacial e temporal.
\end{abstract}

Para Bobbio (1992), os direitos do homem, por mais fundamentais que sejam, são direitos históricos, nascidos em certas circunstâncias, caracterizadas por lutas em defesa de novas liberdades contra velhos poderes. Tiveram uma evolução gradual, não nasceram todos de uma vez e nem de uma vez por todas.

Canotilho (2003) observa que os direitos do homem são os direitos próprios da natureza humana e daí seu caráter inviolável, intemporal e universal; já os direitos fundamentais são os direitos objetivamente vigentes numa ordem jurídica concreta.

A história dos direitos fundamentais tem início com o surgimento do Estado constitucional, cuja essência e razão de ser residem justamente no reconhecimento e na proteção da dignidade da pessoa humana e dos direitos fundamentais do homem (STERN ${ }^{1}$ apud SARLET, 1998).

Os direitos fundamentais evoluíram passando por três fases, quais sejam, a fase clássica, compreendida da antiguidade clássica até o século XVI; a fase intermediária, do século XVII ao XIX, e a de constitucionalização, do século XIX até os dias atuais.

\footnotetext{
${ }^{1}$ STERN, K. In: HBStR V, p. 35.
} 
Desde a antiguidade, na fase clássica, já se tinha inicialmente o sentimento de direito individual, principalmente na Grécia, já que o cidadão ateniense participava ativamente da política. Data daí o início do conceito de cidadania. Cury (2005, p. 4) considera, portanto, que "a cidadania consistia na participação política, mas não havia noção de Estado de Direito, pois havia um Estado totalitário".

Nota-se também a noção de direitos individuais de cunho religioso, desde a antiguidade até a Idade Média. A Bíblia traz o conceito de que todos os homens são iguais; o Homem é a grande obra de Deus. São Tomás de Aquino, participante da elaboração da doutrina católica, influenciou também a formação da doutrina jusnaturalista, já que para ele havia três tipos de leis: 1) a lei Eterna, a lei da Deus (à qual o homem não tem acesso); 2) a lei Natural, por meio da qual Deus se pronuncia diante dos homens (da qual é permitido a esses o conhecimento). Por essa lei, os homens teriam direito à vida e à liberdade; 3) as leis positivas, feitas pelo Estado (observando que o Estado deve respeitar as leis naturais) (CURY, 2005).

Também na fase clássica foi formulada a Carta Magna, na Inglaterra em 1215, considerada o primeiro grande documento que estabelecia limitações aos poderes reais. Porém, não se destinava à proteção de todo o povo, era um contrato entre o rei João Sem Terra e os nobres ingleses, centrando-se na proteção destes.

Já na fase intermediária, a partir do século XVII, iniciou-se a teorização desses direitos, com base racionalista, surgindo a doutrina de Hobbes (1993), de que o homem, antes da organização social, vivia em estado de natureza, de liberdade plena e abriu mão de parte de sua liberdade para a formação do Estado. $O$ estado de natureza de Hobbes e o estado de sociedade de Rousseau (2001) evidenciam uma percepção do social como luta entre fracos e fortes, vigorando a lei da selva ou o poder da força. Para fazer cessar esse estado de vida ameaçador e ameaçado, os humanos decidem passar à sociedade civil, isto é, ao Estado Civil, criando o poder político e as leis. A passagem do estado de natureza à sociedade civil ocorre por meio de um contrato social, pelo qual os indivíduos renunciam à liberdade natural e à posse natural de bens, riquezas e armas e concordam em transferir a um terceiro - o soberano - o poder para criar e aplicar as leis, tornandose autoridade política

Rousseau (2001), a partir desse contrato social, entra para a história como grande elaborador da doutrina contratualista, que traz a passagem da liberdade individual para a liberdade social, consistindo uma das bases da democracia atual. $O$ 
Estado constitucional deve, portanto, garantir direitos. Essa é a razão pela qual os homens aderem ao contrato social, segundo Rousseau. Buscam afirmar direitos que Ihe são próprios, ao mesmo tempo em que exigem do Estado assim criado a obediência a normas cujo fim único é impedir qualquer ameaça àqueles direitos (DALLARI, 1995).

A fase de constitucionalização, do século XIX até os dias atuais, caracterizase pela positivação dos direitos fundamentais, ou seja, pela legislação escrita de tais direitos. A partir deste ponto, os direitos passam de direitos do homem a direitos fundamentais, uma vez que os direitos humanos incorporados pelos Estados são chamados direitos fundamentais e se concretizam nas Constituições.

As declarações iniciais formais de direitos foram a Declaração dos Direitos do Povo da Virgínia (1776), primeiro documento em que foram registrados por escrito os direitos individuais, a Declaração dos Direitos do Homem e do Cidadão (Declaração Francesa de 1789), que foi a primeira carta de direitos de âmbito nacional, porém anterior à Constituição francesa de 1791. A Carta de Direitos Individuais da Constituição Americana, conhecida como Bill of Rights, foi aprovada em 1791, já que a Constituição Americana de 1787 não compreendia uma Carta de Direitos.

A partir dessas declarações, surgiram, no final do século XVIII e início do século XIX, várias constituições focalizando os direitos individuais. Dentre elas, a primeira Constituição brasileira de 1824, que tratava de direitos individuais, ligados à liberdade, mas ainda não abordava os direitos sociais, que começaram a ser positivados com maior ênfase no século XX (CURY, 2005).

A fase de normatização internacional dos direitos fundamentais começou a partir da década de 1940, com a Declaração Universal dos Direitos Humanos, marco da era da internacionalização dos direitos humanos, elaborada pela Organização das Nações Unidas (ONU) em 1948. A ONU foi criada em 1945 e a Declaração, três anos depois. A Declaração não é entendida como de vinculação dos Estados, ela é tida apenas como aconselhamento, e não como um conjunto de normas coercitivas, pois não é um tratado internacional (CURY, 2005).

Todas as declarações recentes dos direitos do homem compreendem, "além dos direitos individuais tradicionais, que consistem em liberdades, também os chamados direitos sociais, que consistem em poderes" (BOBBIO,1992, p. 21). 
Dallari (1985, p. 7) corrobora essa idéia, quando cita que "cada pessoa deve ter a possibilidade de exigir que a sociedade e todas as demais pessoas respeitem sua dignidade e garantam os meios de atendimento daquelas necessidades básicas".

Para Bobbio (1992), os direitos do homem nascem como direitos naturais universais, posteriormente se desenvolvem passando a direitos positivos particulares (quando cada Constituição incorpora Declarações de Direitos), para finalmente encontrarem a plena realização como direitos positivos universais.

O autor destaca que "o problema fundamental em relação aos direitos do homem, hoje, não é tanto de justificá-los, mas o de protegê-los. Trata-se de um problema não filosófico, mas político" (BOBBIO, 1992, p. 24). Note-se que "o direito internacional dos direitos humanos ergue-se no sentido de resguardar o valor da dignidade humana, concebida como fundamento dos direitos humanos" (PIOVESAN, 2007, p. 108-109).

Assim, na visão de Bobbio (1992, p. 16):

Os direitos humanos são coisas desejáveis, isto é, fins que merecem ser perseguidos, e de que, apesar de sua desejabilidade, não foram ainda todos eles (por toda a parte e em igual medida) reconhecidos; e estamos convencidos de que lhes encontrar um fundamento, ou seja, aduzir motivos para justificar a escolha que fizemos e que gostaríamos fosse feita também pelos outros, é um meio adequado para obter para eles um mais amplo reconhecimento.

Os direitos humanos podem ser melhor compreendidos quando classificados em gerações ou dimensões.

\subsection{Dimensões dos direitos humanos}

O termo dimensão substitui, com vantagem lógica e qualitativa, o termo geração, uma vez que este último poderia induzir apenas a sucessão cronológica e, portanto, suposta caducidade dos direitos das gerações antecedentes, o que não é verdade (BONAVIDES, 2000). 
Os direitos fundamentais de primeira dimensão são os direitos individuais, da liberdade, os primeiros a constarem do instrumento normativo constitucional, ou seja, os direitos civis e políticos. Possuem como titular o indivíduo, são oponíveis ao Estado e tidos como faculdades ou atributos das pessoas. Ostentam, assim, uma subjetividade, que é seu traço mais característico; enfim, são direitos de resistência ou de oposição perante o Estado. Esses direitos estão presentes em todas as constituições das sociedades civis democráticas, não obstante seu caráter de status negativus (CURY, 2005).

Os direitos fundamentais de segunda dimensão são os direitos sociais, culturais e econômicos (BONAVIDES, 2000). Não exigem do Estado uma postura de abstenção, mas uma postura positiva. Esses direitos se tornam tão essenciais quanto os direitos fundamentais de primeira dimensão, tanto por sua universalidade, quanto por sua eficácia. Dessa forma, estão ligados intimamente a direitos prestacionais sociais do Estado perante o indivíduo, bem como assistência social, educação, saúde, cultura, trabalho. Sarlet (1998) explica que esses direitos passam a exercer uma liberdade social, formulando uma ligação das liberdades formais abstratas para as liberdades materiais concretas.

Nesse contexto, esta dimensão marca uma nova fase dos direitos fundamentais, não só pelo fato destes direitos terem o escopo positivo, mas também de exercerem uma função prestacional estatal para com o indivíduo.

$\mathrm{Na}$ evolução dos direitos fundamentais surgem ainda os direitos de terceira dimensão, que são os direitos de fraternidade ou solidariedade ou direitos coletivos. O homem deixa de ser visto como indivíduo e passa a merecer proteção coletiva. Os direitos fundamentais de quarta dimensão são os direitos de manipulação genética, relacionados à biotecnologia e à bioengenharia; envolvem questões sobre a vida e a morte e requerem discussão ética (CURY, 2005).

Para Bonavides (2000, p. 524-526), "globalização política na esfera da normatividade jurídica introduz os direitos de quarta geração, que, aliás, correspondem à derradeira fase de institucionalização do Estado social".

Segundo ele, os direitos da quarta dimensão consistem no direito à democracia participativa, direito à informação e o direito ao pluralismo, e acrescenta que "deles depende a concretização da sociedade aberta ao futuro, em sua dimensão de máxima universalidade, para a qual parece o mundo inclinar-se no plano de todas as relações de convivência" (BONAVIDES, 2000, p. 526). Assim, 
Cury (2005, p. 16) conclui que "os direitos de quarta dimensão compreendem o futuro da cidadania e o porvir da liberdade de todos os povos".

Apesar de ser mencionada essa divisão, enfatiza-se que os direitos humanos são indivisíveis e inter-relacionados, ou seja, um depende do outro. Nesse ponto, há que se esclarecer quanto aos direitos fundamentais. Nesse sentido, todo dispositivo da Constituição Federal é possuidor de determinado grau de eficácia e aplicabilidade, devido à normatização imposta pelo Poder Constituinte. O principal dispositivo que dá guarida a esta preleção acerca dos direitos fundamentais no Brasil é o $\S^{\circ}$ do artigo 5ํㅡ da Carta Magna, que dispõe: "as normas definidoras dos direitos e garantias fundamentais têm aplicação imediata" (HUMENHUK, 2004).

Portanto, os textos constitucionais são permeados pelos direitos fundamentais, adquirindo lugar privilegiado nas Constituições. Os direitos fundamentais, como já explicitados anteriormente, assumem inicialmente o caráter de direitos negativos, que importam uma restrição à ação do Estado para, posteriormente, representarem uma postura ativa, exigindo ações positivas do Estado, ou prestações positivas, como no caso dos direitos sociais.

Por estar entre os direitos fundamentais sociais, ou prestacionais, o direito à saúde constitui um dos elementos que marcam o constitucionalismo liberal para o constitucionalismo social, para a existência no texto constitucional de direitos à prestação, direitos que impõem um dever ao Estado (HUMENHUK, 2004).

\subsection{Direito à saúde}

O direito à saúde no Brasil tem passado por várias transformações ao longo do tempo, que indicam melhorias no sistema de saúde brasileiro em direção ao acesso universal aos serviços de saúde. Este direito foi reconhecido internacionalmente, a partir da reorganização política internacional em meados do século XX com a criação da Organização Mundial de Saúde (OMS) em 1948. A partir disto, a saúde foi então, aclamada como um dos direitos fundamentais de todo ser humano, sem distinção de raça, religião, credo, crença política, condição social 
ou econômica, e conceituada como completo bem-estar físico, mental e social e não apenas ausência de doença ou outros agravos (BRASIL, 2007; ROCHA, 1999).

A Constituição de 1988 (CRFB/1988) afirma explicitamente o direito de todos à saúde. Este direito deve ser compreendido sempre dentro dos parâmetros impostos pela mais atualizada doutrina constitucional. Assim, a saúde é reconhecida como direito social (CRFB/1988, art.6º) de todos os brasileiros e estrangeiros residentes no país (CRFB/1988, art. 196, c.c. art.5º) e, para sua garantia imposta literalmente como "dever do Estado" (CRFB/1988, art. 196), esta Constituição define obrigações para todos os níveis de governo da federação (DALLARI, 1995).

Raeffray (2005, p. 264) lembra que a "postulação do direito à saúde implicava, por um lado, na reconceituação da saúde e, por outro, na criação de uma estrutura institucional que viabilizasse e garantisse o gozo deste direito".

Nesse contexto, a autora acrescenta que a revisão do conceito de saúde se faz numa dupla dimensão :

\begin{abstract}
1) como concepção ampliada, incorporando os determinantes sociais do processo saúde/doença em uma perspectiva de atenção integral às necessidades da população, com a superação do paradigma clínico de atenção às enfermidades, para se projetar uma nova divisão de trabalho que atue em todas as funções inerentes à promoção, prevenção e reabilitação, garantindo ao paciente o lugar de sujeito ativo da sua condição sanitária;

2) a saúde assume a condição de função pública, a partir da definição de suas ações e serviços como sendo de relevância pública, reafirmando as prerrogativas do Poder Público de regulação, fiscalização e controle, independentemente do regime de propriedade do provedor (RAEFFRAY, 2005, p. 264-265).
\end{abstract}

A saúde é um direito que se estrutura não só como reconhecimento da sobrevivência individual e coletiva, mas como direito ao bem-estar completo e complexo, tanto biológico, cultural, social, psicológico e ambiental, de acordo com a mencionada definição da OMS (BRASIL, 2006d).

De acordo com Dallari (1995), a incorporação constitucional dos direitos sociais no Brasil foi lenta. Até a promulgação da Constituição Federal de 1988, nenhuma Constituição se referia à saúde como direito social. A primeira república ignorou completamente qualquer direito social e evitou, igualmente, referir-se à saúde. 
Desse modo, para obter legitimidade em meio à modernização econômica excludente e à ação repressiva brutal, os governos militares implantaram certas medidas direcionadas para a população trabalhadora. Com o golpe militar no Brasil, em 1964, os interesses de mercado no setor de saúde se fortalecem e o governo cria, em 1966, o Instituto Nacional de Previdência Social (INPS), consolidando o modelo médico assistencial privatista; estabeleceram-se convênios entre empresas e o INPS para atendimento ao trabalhador nos locais de trabalho; e a previdência foi estendida para várias categorias rurais, até então, não incorporadas ao sistema, embora mantendo restrições para vários desses segmentos (BRASIL, 2006d; MENDES, 1999).

Em meados dos anos 1970, diante da crise social vivida no Brasil, o Movimento Sanitário foi impulsionado pela articulação entre intelectuais, acadêmicos e profissionais de saúde que se encontravam insatisfeitos com as iniqüidades em saúde vigentes até então. Esse movimento passou a lutar por um Sistema Único de Saúde, universal e equânime e pela redemocratização do país, concretizados uma década mais tarde (DA ROS, 2005; ESCOREL, 1998).

No início da década de 1980, o Estado autoritário-militarista enfrenta a crise de suas políticas setoriais, dentre as quais a da previdência e da saúde. Com o estabelecimento desta crise, em 1981 foi constituído o Conselho Consultivo de Administração da Saúde Previdenciária (CONASP), composto por profissionais da medicina, representantes de vários ministérios, trabalhadores, sindicatos e empresas médicas, com o objetivo de reorganizar a assistência médica nacional, fundamental para a abertura democrática nesse segmento, estabelecendo um conjunto de medidas saneadoras e racionalizadoras no âmbito da assistência médico-hospitalar (BRASIL, 2006d; PAIM, 1984; RAEFFRAY, 2005).

Uma das medidas adotadas pela ação do CONASP foi a criação do Programa de Ações Integradas da Saúde (AIS), consideradas um avanço rumo à proposta do Sistema Único de Saúde, que foram implantadas em 1983, como um programa de atenção médica para áreas urbanas, viabilizando a articulação entre o Instituto Nacional de Assistência Médica da Previdência Social (INAMPS), o Ministério da Saúde e as Secretarias Estaduais de Saúde, como meio de formar uma rede pública unificada (BRASIL, 2006a; LIMA et al., 2009; RAEFFRAY, 2005).

Posteriormente, as AIS foram transformadas no Sistema Único Descentralizado de Saúde - SUDS, cuja implantação foi realizada pelo decreto 
presidencial n. 94.657 de 20 de julho de 1987 (BRASIL, 1987), e que teve como objetivo "contribuir para a consolidação e desenvolvimento qualitativo das Ações Integradas de Saúde", com base nos princípios definidos pela Reforma Sanitária, quais sejam: atendimento universal, integralidade da atenção, regionalização e hierarquização, descentralização administrativa, gerenciamento democrático e política integrada de recursos humanos. A idéia era fortalecer o setor público e enfraquecer o segmento privado contratado pelo INAMPS, melhorando o segmento privado filantrópico.

O ano de 1986 constituiu-se em um marco na história das políticas de saúde do Brasil com a realização da 8ª Conferência Nacional de Saúde, o acontecimento político-sanitário mais relevante da época. De caráter democrático, com maciça adesão de diferentes setores da sociedade (MENDES, 1999), o tema saúde como dever do Estado e direito do cidadão foi incluído na pauta dessa conferência, bem como a reformulação do Sistema Nacional de Saúde e o financiamento setorial, priorizando as relações entre saúde e cidadania (FINKELMAN, 2002).

"A institucionalização do direito à saúde sepulta o modelo excludente do Seguro Social, até então adotado pela Previdência Social. Na verdade a Reforma Sanitária iniciou a reconstrução da relação Estado-Sociedade" (RAEFFRAY, 2005, p. 265). Nesse momento, a saúde passou teoricamente de uma saúde apenas dos cidadãos que tivessem emprego, para uma saúde universal.

As reformas setoriais dos anos 80 do século XX visando acesso universal, integralidade da atenção, ênfase em ações de promoção e proteção da saúde, descentralização e participação social, adquiriram expressão legal e institucional com a CRFB/1988 e com a integração dos serviços de saúde pública através do Sistema Único de Saúde (SUS) (CURY, 2005).

A instituição do SUS produziu resultados imediatos. O mais importante foi 0 fim da separação que havia no sistema público de saúde brasileiro entre os incluídos e os não incluídos economicamente. Nessa época, os brasileiros estavam divididos em três categorias, quais sejam: os que podiam pagar pelos serviços; os que tinham direito à assistência prestada pelo INAMPS e os que não tinham nenhum direito, que eram chamados indigentes (ANDRADE; ANDRADE, 2010).

Para os incluídos, trabalhadores de carteira assinada, havia a saúde previdenciária a que tinham direito os portadores da "carteirinha" do INAMPS; para os não incluídos restavam a atenção ambulatorial provida por unidades de medicina 
simplificada e a atenção hospitalar prestada por entidades filantrópicas aos indigentes. Assim, o SUS, no que se refere ao atendimento, abrange todas as pessoas. Essa universalidade do atendimento substituiu a medicina social ofertada pela Previdência Social apenas aos trabalhadores, trazendo a universalidade no acesso aos serviços de saúde (BRASIL, 2006a; MENDES, 1999; RAEFFRAY, 2005).

Nesse sentido, de acordo com a CRFB/1988, a saúde é estabelecida no art. 196 como:

....um direito de todos e dever do Estado, garantido mediante políticas sociais e econômicas que visem à redução do risco de doença e de outros agravos e ao acesso universal e igualitário às ações e serviços para sua promoção, proteção e recuperação (BRASIL, 1988).

A partir da inserção da saúde como direito fundamental, garantido pela CRFB/1988, houve então a promulgação da Lei 8.080/90, Lei Orgânica da Saúde, que institui o Sistema Único de Saúde (SUS), que traria a garantia de atendimento médico universal a toda população brasileira.

O SUS está definido no artigo 4ํㅡㅁ Lei nํㅛ 8.080 de 1990 como:

o conjunto de ações e serviços de saúde, prestados por seus órgãos e instituições públicas, federais, estaduais e municipais, da administração direta e indireta e das fundações mantidas pelo Poder Público, podendo a iniciativa privada atuar em caráter supletivo (BRASIL, 1990).

Estruturalmente, o SUS está organizado em uma rede regionalizada e hierarquizada, ou seja, em espaços populacionais preestabelecidos e segundo um critério de complexidade tecnológica. Em outras palavras, o SUS está fundamentado em princípios de descentralização, participação da comunidade, priorização das atividades preventivas, direção única em cada esfera de governo e atendimento integral (BRASIL, 2003; RAEFFRAY, 2005).

Para melhor compreensão, esses princípios podem ser divididos em éticopolíticos e organizativos. 
Hoje, compreende-se por princípios ético-políticos do SUS:

- a universalidade do acesso, compreendida como a garantia de acesso aos serviços de saúde para toda a população, em todos os níveis de assistência, sem preconceitos ou privilégios de qualquer espécie;

- a integralidade da atenção, como um conjunto articulado e contínuo de ações e serviços preventivos e curativos, individuais e coletivos, em todos os níveis de complexidade do sistema;

- a eqüidade, que embasa a promoção da igualdade com base no reconhecimento das desigualdades que atingem grupos $e$ indivíduos, e na implementação de ações estratégicas voltadas para sua superação; $\mathrm{e}$

- a participação social, que estabelece o direito da população de participar das instâncias de gestão do SUS, por meio da gestão participativa, e dos conselhos de saúde, que são as instâncias de controle social. Essa participação social significa a coresponsabilidade entre Estado e sociedade civil na produção da saúde, ou seja, na formulação, na execução, no monitoramento e na avaliação das políticas e programas de saúde.

Os princípios organizativos do SUS são:

- a intersetorialidade, que prescreve o comprometimento dos diversos setores do Estado com a produção da saúde e o bem-estar da população;

- a descentralização político-administrativa, conforme a lógica de um sistema único, que prevê, para cada esfera de governo, atribuições próprias e comando único;

- a hierarquização e a regionalização, que organizam a atenção à saúde segundo níveis de complexidade - básica, média e alta oferecidos por área de abrangência territorial e populacional, conhecidas como regiões de saúde; e

- a transversalidade, que estabelece a necessidade de coerência, complementaridade e reforço recíproco entre órgãos, políticas, programas e ações de saúde (BRASIL, 2007, p. 8-9).

Dessa forma, a consolidação do SUS, como um sistema de atenção e cuidados em saúde, não é suficiente para a efetivação do direito da população à saúde. São claras as evidências que apontam para os limites da atuação de um sistema de assistência. A conquista da saúde precisa estar articulada à ação sistemática e intersetorial do Estado sobre os determinantes sociais de saúde, ou seja, o conjunto dos fatores de ordem econômico-social e cultural que exercem influência direta ou indireta sobre as condições de saúde da população (BRASIL, 2006d).

Diversos avanços e desafios podem ser exemplificados nestes 20 anos de instituição do Sistema Único de Saúde. Entretanto, o SUS "tem sido capaz de estruturar e consolidar um sistema público de saúde de enorme relevância e que apresenta resultados inquestionáveis para a população brasileira" (BRASIL, 2006a, p. 31). 
Um dos avanços a serem citados é o da Estratégia Saúde da Família, a evolução e aumento das equipes envolvidas, melhorando sensivelmente 0 atendimento das comunidades atendidas pelo programa. Esses avanços podem ser constatados pela qualidade de alguns programas que têm desempenho igual ou superior aos de outros países, até mesmo dos países desenvolvidos. É o caso dos programas de vacinação, transplantes e HIV/AIDS (BRASIL, 2006a; MENICUCCI, 2009).

Com mais de 30 anos de existência, o Programa Nacional de Imunizações (PNI), se destaca como um dos programas de grande importância da saúde brasileira. A estratégia de dias nacionais de vacinação, desenvolvida no Brasil, foi adotada por vários países. O Brasil já atingiu e, em muitos casos, superou os patamares de imunização dos países desenvolvidos. O Sistema Nacional de Transplantes, instituído em 1997, é um dos maiores programas públicos de transplante de órgãos do mundo. (BRASIL, 2006a; SILVA, 2009).

Outro ponto a ressaltar é o caso da saúde mental, já que no período de 19942004, houve uma queda de $46,43 \%$ das internações hospitalares e incremento de $765,67 \%$ nos atendimentos psicossociais ambulatoriais, revelando que a política nacional de desospitalização e humanização da atenção aos portadores de sofrimento mental está evoluindo, apesar de várias dificuldades (BRASIL, 2006a; MENDES, 1999).

O SUS, além de mostrar avanços em termos de estrutura e processos e de estar desenvolvendo programas de excelência, tem contribuído para a melhoria dos níveis de saúde da população brasileira.

Existem, contudo, desafios a serem superados: o desafio da universalização; o desafio do financiamento; o desafio do modelo institucional; o desafio do modelo de atenção à saúde; o desafio da gestão do trabalho; e o desafio da participação social (BRASIL, 2006a; MENICUCCI, 2009; SANTOS, 2009; SILVA, 2009; VIANA; MACHADO, 2008).

Alguns exemplos podem ser descritos como o desafio da universalização, consubstanciado na dificuldade de se atingir toda população brasileira e potencializado pela segmentação da saúde, ou seja, pela inserção de serviços privados de saúde.

O financiamento do SUS é também insuficiente, a ponto de impedir não somente a implementação progressiva/incremental do sistema, como e 
principalmente de avançar na reestruturação do modelo e procedimentos de gestão, em função do cumprimento do SUS como um sistema público universal. É verdade que se gasta pouco em saúde no país, especialmente no que concerne ao gasto público. Todavia, também, se gasta mal. Nesse sentido, é fundamental que se crie uma consciência interna no SUS de que se deverá melhorar a qualidade do gasto. Portanto, o desafio do financiamento na saúde tem que ser enfrentado em duas vertentes, a da quantidade e a da qualidade do gasto. Haverá que se aumentar o gasto em saúde, mas, ao mesmo tempo, melhorar sua qualidade (BRASIL, 2006a; SANTOS, 2009).

Ressalta-se, ainda, o modelo de gestão do trabalho que é marcado estruturalmente por diminuição do número de trabalhadores, em virtude das suspensões de concursos públicos e a terceirização do quadro de funcionários, resultando na precarização das relações de trabalho e em um número excessivo de atendimentos, diminuindo a qualidade do serviço e levando à dificuldade de se conseguir a humanização do cuidado (SANTOS, 2009).

Apesar desses desafios, o SUS, deve ser reconhecido, como um importante mecanismo de cobertura social no que diz respeito à saúde, servindo como apoio para superar a fragmentação e a exclusão crescentes na sociedade brasileira atual. Convém sinalizar, no entanto, que tanto os gestores, profissionais e usuários, quanto o governo são responsáveis pela coordenação de esforços para estruturar um SUS eficiente e eficaz. Logo, quanto mais o planejamento desse sistema estiver articulado e integrado com a coletividade, tanto maior será a garantia de um serviço de saúde com qualidade e eqüidade (BACKES et al., 2009).

O direito à saúde implica no reconhecimento de que todos os cidadãos, sem exceção, tenham garantias universais da saúde. Os movimentos sociais dos anos pré-constituição, na área da saúde, visavam um novo paradigma e uma nova forma de considerar a saúde da população, coletiva e individualmente, como direito de todos, sobre a qual os sujeitos implicados tomam decisões. A participação é essa nova articulação do poder com todos os envolvidos, na transformação de atores passivos em sujeitos ativos, de atores individuais em atores coletivos (BRASIL, 2006d).

Além da CRFB/1988 e da Lei Orgânica, há vários instrumentos normativos que caracterizam o direito à saúde no Brasil. Constata-se no país uma verdadeira pluritutela normativa da saúde. Dentre os diferentes instrumentos legais, enfatiza-se 
a Lei Estadual 10.241/1999, que dispõe sobre os direitos dos usuários dos serviços e das ações de saúde no Estado de São Paulo e dá outras providências" (SÃO PAULO, 1999).

De acordo com a Lei 10.241/1999:

Art. 2: São direitos dos usuários dos serviços de saúde no Estado de São Paulo:

VI - receber informações claras, objetivas e compreensíveis sobre:

a) hipóteses diagnósticas;

c) exames solicitados;

d) ações terapêuticas;

e) riscos, benefícios e inconvenientes das medidas diagnósticas e terapêuticas propostas;

f) duração prevista do tratamento proposto;

g) no caso de procedimentos de diagnósticos e terapêuticos invasivos, a necessidade ou não de anestesia, o tipo de anestesia a ser aplicada, o instrumental a ser utilizado, as partes do corpo afetadas, os efeitos colaterais, os riscos e conseqüências indesejáveis e a duração esperada do procedimento;

h) exames e condutas a que será submetido;

i) a finalidade dos materiais coletados para exame;

j) alternativas de diagnósticos e terapêuticas existentes, no serviço de atendimento ou em outros serviços; e

I) o que julgar necessário;

VII - consentir ou recusar, de forma livre, voluntária e esclarecida, com adequada informação, procedimentos diagnósticos ou terapêuticos a serem nele realizados;

VIII - acessar, a qualquer momento, o seu prontuário médico, nos termos do artigo $3^{\circ}$ da Lei Complementar n. 791, de 9 de março de 1995;

$\mathrm{XI}$ - receber as receitas:

a) com o nome genérico das substâncias prescritas;

b) datilografadas ou em caligrafia legível;

c) sem a utilização de códigos ou abreviaturas;

d) com o nome do profissional e seu número de registro no órgão de controle e regulamentação da profissão; e

e) com assinatura do profissional (SÃO PAULO, 1999).

A partir da descrição desta lei, observa-se a importância da qualidade da informação recebida pelo usuário do serviço de saúde, que possui direito respaldado por lei a um atendimento e a informações claras e detalhadas sobre exames, procedimentos e receitas legíveis.

Assim, dentre os direitos dos usuários dos serviços de saúde, ressalta-se o direito à informação em saúde. 


\subsection{Informação}

Por informação entende-se "o conhecimento de fatos, de acontecimentos, de situações de interesse geral e particular que implicam do ponto de vista jurídico, duas direções: a do direito de informar e a do direito de ser informado" (GRECO² apud SILVA, 2005, p. 245).

A primeira, segundo o autor, é a liberdade de manifestação do pensamento pela palavra, por escrito ou por qualquer outro meio de difusão; a segunda indica o interesse sempre crescente da coletividade para que tanto os indivíduos como a comunidade estejam informados para o exercício consciente das liberdades públicas. Assim, Gomes (2008) aponta que a informação é pública enquanto o conhecimento é privado. Pode-se transmitir, distribuir e disseminar a informação, mas o conhecimento não faz este percurso. A sua circulação apenas é possível com a sua representação pela informação.

Le Roy (1997, p. 28) acrescenta que:

Quando se deseja compartilhar um conhecimento, este deve ser traduzido em informações, para que o destinatário possa absorvê-las e transformá-las em conhecimento - se ele quiser.

Nesse sentido, a informação pode ser entendida também como um conhecimento inscrito sob a forma escrita, oral ou audiovisual. Ela comporta um elemento de sentido e é transmitida a um ser consciente por meio de uma mensagem inscrita (LE COADIC, 2004, grifo nosso).

Diante disto, mesmo o direito à informação sendo um direito coletivo, ou da coletividade, verifica-se também que "o acesso de todos à informação é um direito individual consignado na Constituição Art. 5ํ, XIV, que resguarda o sigilo da fonte, quando necessário ao exercício profissional” (SILVA, 2005, p. 246).

\footnotetext{
${ }^{2}$ GRECO, A. La libertà di stampa nele' ordinamento giuridico italiano. Roma : Bulzioni Editores, 1974.
} 


\title{
2.2 Acesso à informação
}

Ao mencionar o acesso de todos à informação como um direito individual, ressalta-se o direito fundamental à informação em saúde, ou seja, o direito que o usuário de um serviço público de saúde tem de ser informado sobre todos os aspectos que envolvam a sua saúde, que asseguram o acesso à informação por direito.

Diante dessa premissa, enfatiza-se a diferença entre o acesso físico e o acesso cognitivo da informação.

Entende-se como acesso físico, o acesso palpável, ou seja, ter em mãos a informação escrita, ter acesso ao suporte físico da informação, como por exemplo, ter acesso à lei de direito dos pacientes, ao seu prontuário, ao termo de consentimento livre e esclarecido e a informações detalhadas sobre sua saúde.

Sobre o acesso cognitivo, há um questionamento de como se dá a aquisição cognitiva deste conhecimento, já que a partir da definição de Mussen et al. (1988, p. 210):

\begin{abstract}
A cognição é um conceito amplo e abrangente que se refere às atividades mentais envolvidas na aquisição, processamento, organização e uso do conhecimento. Os processos principais envolvidos no termo cognição incluem detectar, interpretar, classificar e recordar informação; avaliar idéias; inferir princípios e deduzir regras; imaginar possibilidades; gerar estratégias; fantasiar e sonhar.
\end{abstract}

Pode-se dizer, então, que a cognição envolve vários processos mentais: a atenção, a percepção, a memória, o raciocínio, o juízo, o pensamento, a imaginação e o discurso (CITI, 2006).

Nessa perspectiva, Valentim (2008) ressalta que somente se pode chamar de "informação" algo que se compreende, isto é, se existe por parte do sujeito cognoscente, consenso em relação ao seu significado. Caso contrário, não é informação. Outro aspecto que a autora destaca, refere-se às qualidades relevância e propósito inerentes ao termo "informação", já que o sujeito cognoscente busca a informação com determinado objetivo, seja conscientemente ou inconscientemente, necessitando porém de mediação humana, pois, o que é informação para um pode não ser para outro. 
Para um usuário do serviço de saúde, pode ser natural receber determinadas informações, como por exemplo, resultados de exames. Porém, alguns usuários necessitam de explicações mais detalhadas, enquanto outros, dependendo do grau de instrução e conhecimento do assunto, precisam de menos explicações. A informação quando mediada pelo profissional de saúde, necessita da adequação à pessoa, uma vez que a informação que um indivíduo necessita pode não ser entendida por outro da mesma maneira. Assim, o usuário ou sujeito cognoscente ressignifica a informação, sintetizando-a e contextualizando-a em sua vivência.

Para tanto, Fortes (1994) acrescenta que as informações devem ser adaptadas às circunstâncias do caso e às condições sociais, psicológicas e culturais, utilizando-se um padrão orientado para cada pessoa, denominado "padrão subjetivo".

Este padrão pode ser entendido como uma abordagem informativa apropriada a cada indivíduo. A discussão sobre cada situação deve ser feita adaptando-se aos valores e expectativas psicológicas e sociais de cada pessoa, sem se ater a fórmulas padronizadas. Os usuários devem ser, portanto, considerados únicos, não padronizáveis e o consentimento com a adequada informação deve basear-se, não só na escolha de uma melhor alternativa científica, mas na melhor alternativa para aquela pessoa (COELHO et al. 2008; ENGELHARDT, 2004; FORTES, 1994; 2005).

Diante dessas considerações, acrescenta-se o que diz a Portaria do Ministério da Saúde sobre direito do paciente:

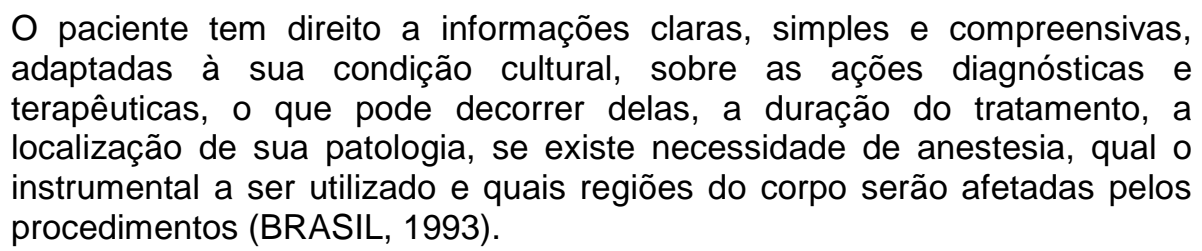

O paciente tem direito a informações claras, simples e compreensivas, adaptadas à sua condição cultural, sobre as ações diagnósticas e terapêuticas, o que pode decorrer delas, a duração do tratamento, a localização de sua patologia, se existe necessidade de anestesia, qual o procedimentos (BRASIL, 1993).

Nesse contexto, ressalta-se a importância da mediação pelo profissional de saúde adotando sempre um padrão subjetivo a cada usuário para que se tenha o acesso cognitivo da informação mediada. 


\subsection{A mediação e o empoderamento da informação pelo paciente}

Segundo Davallon (2003) a mediação é a ação de servir de intermediário ou ser o que serve de intermediário numa comunicação, não sendo essa ação apenas o estabelecimento de uma simples relação entre dois termos de mesmo nível, mas que em si produz "algo a mais", ou um estado mais satisfatório. Gellereau (2006) argumenta que a mediação implica sempre acompanhamento, controle e negociação por um "terceiro", enquanto o sujeito que se beneficia de um processo de mediação é levado a aprofundar o seu próprio ponto de vista e a descobrir outros.

A partir dessas concepções, Almeida Júnior (2009, p. 92) conceituou ainda de maneira embrionária, a mediação da informação como:

\footnotetext{
...toda ação de interferência, realizada pelo profissional, direta ou indireta; consciente ou inconsciente; singular ou plural; individual ou coletiva; que propicia a apropriação de informação que satisfaça, plena ou parcialmente, uma necessidade informacional.
}

Neste conceito, o autor destaca que é ela uma interferência, sendo que a imparcialidade e a neutralidade, normalmente encontradas nas atividades profissionais, aqui não se concretizam. Dessa forma, o profissional que deve ser neutro e imparcial em suas colocações, nesse caso, atua como "sujeito mediador" e, diante disto, não é neutro, pois, ao mediar a informação carrega também ideologias que sempre vêm acompanhadas de interesses, sejam econômicos, políticos ou culturais (ALMEIDA JÚNIOR, 2009).

O mediador deve, então, ser capaz de minimizar o desequilíbrio de poder encontrado nas relações entre o profissional e usuário do serviço. Nesse sentido, Barros e Fortes (2003) e Carmo (2002) discutem a relação de poder existente entre o desconhecimento ou falta de informação do usuário sobre seus direitos e a conduta médica de não esclarecer ou prestar informações sem se preocupar com a adoção de um padrão subjetivo dirigido a cada paciente, já que, pela ótica institucional, o paciente está sendo tratado com qualidade.

Entende-se como poder, nesse contexto, a força usada para fazer as coisas acontecerem de uma forma pretendida, tendo como essência, o controle sobre o comportamento de outros (SCHERMERHORN; HUNT; OSBORN, 2005). 
Observam-se poderes que se enquadram no que se refere à relação profissional de saúde-paciente. Tem-se o poder de posição ou cargo, derivado da autoridade formal e o poder de legitimidade, quando sustentado ou reconhecido como verdadeiro pelas pessoas influenciadas por ele. O poder de posição pode se tornar legítimo, com base nos valores e crenças que o paciente tem pré-concebidos sobre o profissional.

Já o poder pessoal está no indivíduo, independente da posição que ele ocupa. O poder pessoal de especialização é a capacidade de controlar o comportamento de outras pessoas por meio da posse do conhecimento, experiência ou julgamento que os outros não têm, mas precisam (SCHERMERHORN; HUNT; OSBORN, 2005). No caso em questão, o paciente supõe que o profissional saiba mais a respeito do que precisa ser feito ou como deve ser feito. Sendo assim, o elemento do "controle de informações" é importante base para o poder.

Assim, sem a informação, que lhe é devida por direito, o usuário não é capaz de reivindicar e/ou lutar pelos seus direitos, não tem condições e nem argumentos para questionar, dificultando, dessa forma, o exercício de sua autonomia e de sua cidadania.

De acordo com Pinsky e Pinsky (2003, p. 3):

...ser cidadão é ter direito à vida, à liberdade, à propriedade, à igualdade perante a lei: é, em resumo, ter direitos civis. É também participar no destino da sociedade, votar, ser votado, ter direitos políticos. Os direitos civis e políticos não asseguram a democracia sem os direitos sociais, aqueles que garantem a participação do indivíduo na riqueza coletiva: à educação, ao trabalho, ao salário justo, à saúde, a uma velhice tranqüila. Exercer a cidadania é ter direitos civis, políticos e sociais.

Partindo desta hipótese, o exercício da cidadania pelos usuários está diretamente relacionado ao seu empoderamento. Compreende-se por empoderamento, o processo pelo qual os que detêm o poder, no caso, os profissionais de saúde, favorecem aos outros (usuários) a adquirirem e usarem o poder necessário (empoderamento da informação) para tomar decisões que afetam a si ou sua vida. Não se deve considerar o poder apenas nos níveis mais altos, mas como algo que pode ser compartilhado por todos (SCHERMERHORN; HUNT; OSBORN, 2005). 
O empoderamento do indivíduo por meio da informação tem papel fundamental no processo de auto-transformação da pessoa, na medida em que propicia um ambiente de mudanças com o intuito de oferecer aos indivíduos envolvidos certa autonomia (FREIRE, 2003). Carvalho (2004, p. 1092) afirma ainda que o "empoderamento é uma forma de redistribuir o poder que se encontra desigualmente distribuído na sociedade".

Nesse contexto, Almeida Júnior (2009) ressalta que a mediação da informação permite o deslocamento do usuário da categoria de mero receptor, colocando-o como ator central do processo de apropriação, ou seja, o empoderamento da informação pelo usuário o desloca da categoria de receptor passivo da informação a um ser ativo e participativo, e, portanto, cidadão. $\mathrm{O}$ autor defende ainda que:

...o usuário é quem determina a existência ou não da informação. A
informação existe apenas no intervalo entre o contato da pessoa com o
suporte e a apropriação da informação. Como premissa, entende-se a
informação a partir da modificação, da mudança, da reorganização, da
reestruturação, enfim, da transformação do conhecimento. Assim entendida,
ela, informação, não existe antecipadamente, mas apenas na relação da
pessoa com o conteúdo presente nos suportes informacionais. Estes são
concretos, mas não podem prescindir dos referenciais, do acervo de
experiências e do conhecimento de cada pessoa. Em última instância, quem
determina a existência da informação é o usuário, aquele que faz uso dos
conteúdos dos suportes informacionais. Considerada a informação desse
modo, é clara a participação ativa e decisiva do usuário no processo. De
receptor, passa o usuário a ser um construtor, um co-produtor da
informação (ALMEIDA JúNIOR, 2009, p. 96-97).

Ao destacar essa relação do processo de geração de conhecimento, é mister que se identifique os três tipos de usos da informação a partir da concepção de Buckland (1991) e Wellisch (1972): informação como coisa, como conhecimento e a informação como processo.

A informação como coisa relaciona-se aos objetos considerados como sendo informativos em suas características físicas, tais como o dado e os documentos expressos, descritos ou representados por alguma forma física como o sinal, o texto ou a sua comunicação. Outros entendimentos podem ser encontrados na literatura, prevalecendo a idéia de que o dado gera a informação que gera o conhecimento. 
A informação como conhecimento tem uma de suas formas quando reduz as incertezas. O conhecimento comunicado refere-se a algum fato, assunto ou evento dado como notícia, informado, dito, que se reflete no conhecimento, sendo, entretanto, intangível, não podendo ser tocado ou medido.

Como processo, a informação muda o conhecimento de alguém e é situacional. A ação de relatar ou o fato de começar a relatar sobre algo caracteriza a informação como processo. É o ato de informar um objeto, um documento, um dado, um fato, um evento. A relevância do dado ou fato é situacional e depende do nível de conhecimento de quem recebe a informação no momento da recepção.

O processo de construção do conhecimento ocorre por meio de um movimento complexo, no qual os sujeitos interagem entre si, mas também com as informações, processando-as para, a partir de seus enquadramentos, de suas possibilidades cognitivas, se apropriarem dos conteúdos acessados (GOMES, 2008), ou seja, a "geração de conhecimento somente é possível quando a informação é interiorizada pelo sujeito, propiciando, por meio do estabelecimento de relações cognitivas, novo conhecimento, que pode ser aplicado" (VALENTIM, 2008, p. 12-13).

Essa transformação da informação em conhecimento é realizada em âmbito individual. Porém, a pessoa, o indivíduo, não é vazio, ou seja, não tem espaços vazios nos quais o conhecimento, fruto da apropriação da informação, se aloja. A pessoa possui um conhecimento prévio, um conhecimento tácito e o constrói na relação com os outros e com o mundo. Nessa perspectiva, a informação altera um conhecimento preexistente, interferindo na construção desse novo conhecimento. Este, é construído a partir de toda influência que o indivíduo tem com o mundo, sejam elas influências sociais, políticas, econômicas ou culturais (ALMEIDA JÚNIOR, 2008).

A informação em saúde insere-se nesse contexto, ou seja, o ato de informar o paciente sobre sua saúde ou doença, e sobre todos os aspectos que a constituem. A informação em saúde é vista como processo, tornando possível a apropriação da informação pelo usuário. O mediador, que pode ser o médico, o enfermeiro ou qualquer profissional de saúde torna-se elemento essencial nessa apropriação de informação, uma vez que é ele quem serve de intermediário na comunicação.

As informações, especificamente os dados, quais sejam: diagnósticos, prognósticos, os resultados dos exames, as explicações sobre prescrições, 
medicamentos, interações medicamentosas, entre outros, são analisados como coisa informada, propiciando assim o conhecimento do indivíduo acerca de seus direitos enquanto usuário do serviço de saúde.

Enfim, a informação em saúde transformada em conhecimento, pode levar a apropriação da informação pelo paciente, empoderando-o e trazendo possibilidades para que ele exerça efetivamente seu direito à saúde. 


\subsection{Tipo de pesquisa}

Trata-se de pesquisa qualitativa, de caráter exploratório, com orientação analítico-descritiva. Os estudos exploratórios, segundo Gil (1999, p. 43), "são desenvolvidos com o objetivo de proporcionar visão geral, de tipo aproximativo, acerca de determinado fato".

Os estudos descritivos têm por finalidade "observar, descrever e explorar os aspectos de uma situação, ou seja, descrever com exatidão os fatos ou fenômenos de uma determinada realidade" (POLIT; BECK; HUNGLER, 2004, p. 177).

Caracteriza-se este estudo como exploratório, uma vez que objetiva descrever de modo geral e aproximado a compreensão dos usuários do SUS sobre o seu direito à informação em saúde.

A orientação analítico-descritiva consolida-se com a análise integral das falas dos sujeitos, descrevendo o conhecimento dos usuários sobre seu direito à informação em saúde, bem como a importância atribuída ao recebimento dessas informações.

A escolha pela abordagem qualitativa deve-se ao fato de que ela responde a questões particulares, sendo que, nas ciências sociais e na educação, trabalha com significados, motivos, aspirações, crenças, valores e atitudes, ou seja, preocupa-se com um nível de realidade que nem sempre pode ser quantificado. É um tipo de abordagem que privilegia a vivência, a compreensão e o entendimento dos sujeitos pesquisados perante a temática abordada (MINAYO, 2008).

Nesse sentido, a opção por essa abordagem é corroborada pela necessidade de compreensão e elucidação de sentimentos, conhecimentos dos sujeitos pesquisados, o que não poderia ser quantificado. 


\subsection{Objetivos}

\subsubsection{Objetivo geral}

Identificar o conhecimento de usuários do SUS sobre o seu direito à informação elencados no art. $2^{\circ}$, incisos VI, VII, VIII, e XI da Lei Estadual $10.241 / 1999$.

\subsubsection{Objetivos específicos}

1. Identificar as dificuldades/facilidades observadas pelos usuários do serviço estudado, do setor de Clínica Médica, quanto ao acesso à informação relacionada à sua saúde.

2. Compreender a importância atribuída pelos usuários do serviço estudado ao acesso à informação relacionada à sua saúde.

\subsection{Local do estudo}

O estudo foi realizado em uma Unidade Básica de Saúde localizada no Município de Ribeirão Preto. Esta unidade caracteriza-se por oferecer serviços de emergência 24 horas, a crianças e adultos e atendimento básico, atendendo nas especialidades Clínica Médica, Pediatria, Ginecologia e Obstetrícia, Odontologia, Enfermagem, Assistência Domiciliar, Teste do Pezinho e Vacinação em horários estabelecidos pela unidade. 


\subsection{Sujeitos da pesquisa}

Participaram do estudo 22 usuários da Unidade Básica de Saúde, que foram atendidos em consultas previamente agendadas pelo setor de Clínica Médica da UBDS, não estando, portanto, em situações de urgência e emergência.

Os critérios de inclusão na pesquisa foram: ter idade igual ou superior a 18 anos, ser capaz de se comunicar verbalmente e consentir (por assinatura ou digital) em participar do estudo (Termo de Consentimento Livre e Esclarecido, APÊNDICE A), ser usuário do serviço de saúde público, ter sido consultado em consulta previamente agendada no Setor de Clínica Médica da UBDS e ter concordado em participar do estudo.

A coleta de dados foi realizada nos meses de janeiro, fevereiro e março de 2010, após a autorização da realização da pesquisa pela Secretaria Municipal de Saúde de Ribeirão Preto (ANEXO A) e posterior aprovação pelo Comitê de Ética em Pesquisa da Escola de Enfermagem de Ribeirão Preto (ANEXO B), de acordo com a Resolução 196/96 (BRASIL, 1996). Nesse sentido, este estudo atende o rigor científico e aos preceitos éticos exigidos pela Comissão Nacional de Ética em Pesquisa (CONEP) na realização de Pesquisa com Seres Humanos, garantindo a privacidade, o anonimato, a participação voluntária dos respondentes e a utilização científica dos resultados.

\subsection{Procedimento de coleta dos dados}

A técnica utilizada para a coleta foi a de entrevista semi-estruturada, guiada por um roteiro (APÊNDICE B) e gravada em meio digital, com o consentimento dos participantes sobre a natureza e a importância da pesquisa. Foi realizada em local reservado.

A entrevista semi-estruturada pode ser entendida como aquela que parte de certos questionamentos básicos, apoiados em teorias e hipóteses, que interessam à pesquisa, e que, em seguida, oferecem amplo campo de interrogativas, fruto de 
novas hipóteses, que vão surgindo à medida que recebem as respostas do informante. Dessa maneira, o informante, seguindo espontaneamente a linha de seu pensamento e de suas experiências dentro do foco principal colocado pelo investigador, começa a participar na elaboração do conteúdo da pesquisa (TRIVIÑOS, 1987).

No início da entrevista foram explicados aos participantes os objetivos do estudo e, após o consentimento verbal em participar da pesquisa, foi solicitado que assinassem o termo de consentimento livre esclarecido (APÊNDICE A), conforme normas da Resolução 196/96, do Conselho Nacional de Saúde (BRASIL, 1996).

As entrevistas foram realizadas logo após a consulta médica, na tentativa de coletar os dados durante $\mathrm{O}$ ato reflexivo do paciente sobre o momento vivido recentemente (DESLANDES, 1994; TRIVIÑOS, 1987; MINAYO, 2008). Foram entrevistados 22 pacientes até que as respostas começaram a se tornar repetitivas ou redundantes. A eles foi perguntado sobre o conhecimento pessoal acerca do direito à informação como usuário do serviço de saúde. Considerou-se, portanto, o ponto de saturação para delimitar o número de entrevistados.

Glaser e Strauss (2008) originalmente conceituaram saturação como sendo a constatação do momento de interromper a captação de informações obtidas junto a uma pessoa ou grupo pertinentes à discussão de uma determinada categoria dentro de uma investigação qualitativa sociológica. Na expressão dos autores, tratar-se-ia de uma confiança empírica de que a categoria está saturada, levando-se em consideração uma combinação dos seguintes critérios: os limites empíricos dos dados e a integração de tais dados com a teoria.

De acordo com os objetivos propostos, foram formuladas questões que abarcassem o conteúdo da Lei Estadual 10.241/1999 e também os objetivos específicos da pesquisa. 


\begin{tabular}{|c|c|}
\hline OBJETIVOS & PERGUNTAS DE PESQUISA \\
\hline $\begin{array}{l}\text { Identificar o conhecimento de usuários do SUS } \\
\text { sobre o direito à informação dos pacientes } \\
\text { elencados no art. 20, incisos VI, VII, VIII, e XI da } \\
\text { Lei estadual } 10.241 / 1999 \text {. }\end{array}$ & \\
\hline $\begin{array}{l}\mathrm{VI} \text { - receber informações claras, objetivas e } \\
\text { compreensíveis sobre: a) hipóteses diagnósticas; } \\
\text { b) diagnósticos realizados; c) exames solicitados; } \\
\text { d) ações terapêuticas; e) riscos, benefícios e } \\
\text { inconvenientes das medidas diagnósticas e } \\
\text { terapêuticas propostas; f) duração prevista do } \\
\text { tratamento proposto; g) no caso de procedimentos } \\
\text { de diagnósticos e terapêuticos invasivos, a } \\
\text { necessidade ou não de anestesia, o tipo de } \\
\text { anestesia a ser aplicada, o instrumental a ser } \\
\text { utilizado, as partes do corpo afetadas, os efeitos } \\
\text { colaterais, os riscos e conseqüências indesejáveis } \\
\text { e a duração esperada do procedimento; h) exames } \\
\text { e condutas a que será submetido; i) a finalidade } \\
\text { dos materiais coletados para exame; j) alternativas } \\
\text { de diagnósticos e terapêuticas existentes, no } \\
\text { serviço de atendimento ou em outros serviços; e I) } \\
\text { o que julgar necessário; }\end{array}$ & $\begin{array}{l}\text { Quais informações você normalmente recebe dos } \\
\text { profissionais de saúde ao usar um serviço público } \\
\text { de saúde? [sobre diagnóstico, sobre exames (o } \\
\text { porquê, e finalidade), sobre as ações de cuidado } \\
\text { dos profissionais, sobre os riscos/benefícios do } \\
\text { seu tratamento, duração do tratamento, efeitos } \\
\text { colaterais dos medicamentos ou anestesia] }\end{array}$ \\
\hline $\begin{array}{l}\text { VII - consentir ou recusar, de forma livre, voluntária } \\
\text { e esclarecida, com adequada informação, } \\
\text { procedimentos diagnósticos ou terapêuticos a } \\
\text { serem nele realizados; }\end{array}$ & $\begin{array}{l}\text { Durante a consulta, os profissionais de saúde } \\
\text { perguntaram se você consentiria ou recusaria o } \\
\text { tratamento ou algum procedimento realizado? (Em } \\
\text { caso positivo, você achou esta pergunta } \\
\text { importante? Em caso negativo, por que você acha } \\
\text { que não foi feita esta pergunta a você?) }\end{array}$ \\
\hline $\begin{array}{l}\text { VIII - acessar, a qualquer momento, o seu } \\
\text { prontuário médico, nos termos do artigo } 3^{\circ} \text { da Lei } \\
\text { Complementar n. 791, de } 9 \text { de março de } 1995 ;\end{array}$ & $\begin{array}{l}\text { Você sabe se pode ter acesso ao seu prontuário } \\
\text { médico? Você já teve este acesso? }\end{array}$ \\
\hline $\begin{array}{l}\mathrm{XI} \text { - receber as receitas: a) com o nome genérico } \\
\text { das substâncias prescritas; b) datilografadas ou } \\
\text { em caligrafia legível; c) sem a utilização de códigos } \\
\text { ou abreviaturas; d) com o nome do profissional e } \\
\text { seu número de registro no órgão de controle e } \\
\text { regulamentação da profissão; e e) com assinatura } \\
\text { do profissional }\end{array}$ & $\begin{array}{l}\text { As receitas prescritas a você são normalmente } \\
\text { fáceis de ler? Os medicamentos são genéricos? }\end{array}$ \\
\hline $\begin{array}{l}\text { Identificar as dificuldades/facilidades observadas } \\
\text { pelos usuários do serviço estudado, do setor de } \\
\text { Clínica Médica, quanto ao acesso à informação } \\
\text { relacionada à sua saúde. Compreender a } \\
\text { importância atribuída pelos usuários do serviço } \\
\text { estudado ao acesso à informação relacionada à } \\
\text { sua saúde. }\end{array}$ & $\begin{array}{l}\text { Como você se sente quando recebe informações } \\
\text { sobre o seu estado de saúde, sobre o seu } \\
\text { tratamento, sobre suas possibilidades de escolha } \\
\text { relacionadas a este tratamento? }\end{array}$ \\
\hline
\end{tabular}

Quadro 1 - Inter-relação entre os objetivos e as perguntas de pesquisa. 


\subsection{Análise dos dados}

As falas dos respondentes foram trabalhadas qualitativamente, apenas usando o quantitativo como complemento da pesquisa. Assim, considera-se a pesquisa essencialmente qualitativa. De acordo com o método qualitativo, a análise processou-se simultaneamente à coleta dos dados. Foram identificadas categorias que pudessem responder aos objetivos propostos (MINAYO, 2008).

O material obtido na fase exploratória da pesquisa foi analisado através do método de Análise Temática. Segundo Bardin (1977, p. 107), "o tema é a unidade de significação que se liberta naturalmente de um texto analisado segundo critérios relativos à teoria que serve de guia à leitura".

Ao proceder a análise temática do conteúdo, foram evidenciados núcleos de sentido que compuseram os discursos obtidos nas entrevistas. A presença de determinados assuntos abordados pelos sujeitos resultou na criação de categorias, as quais evidenciaram a representação sobre o conhecimento do paciente sobre seu direito à informação.

Em uma fase inicial, chamada pré-análise, foram selecionados os documentos que seriam utilizados no trabalho. Foram retomados conceitos, objetivos geral e específicos e leituras flutuantes das entrevistas, neste momento já transcritas. Já na segunda fase, de exploração do material, os dados brutos foram sistematizados, ou seja, enumerados, selecionados e divididos em categorias e subcategorias temáticas, com o objetivo de alcançar o núcleo de compreensão do texto, ou o tema. Posteriormente, os temas foram analisados com subsídio da literatura sobre o objeto de estudo com o intuito de atingir as propostas da investigação. Essas categorias temáticas guiaram a discussão. Por fim, na terceira fase, foi realizado o tratamento e interpretação dos resultados obtidos, interpretação esta que culminou com as conclusões finais do trabalho (BARDIN, 1977; MINAYO, 2008).

Após sistematização dos dados foram identificadas as seguintes categorias e subcategorias temáticas de acordo com o quadro 2: 


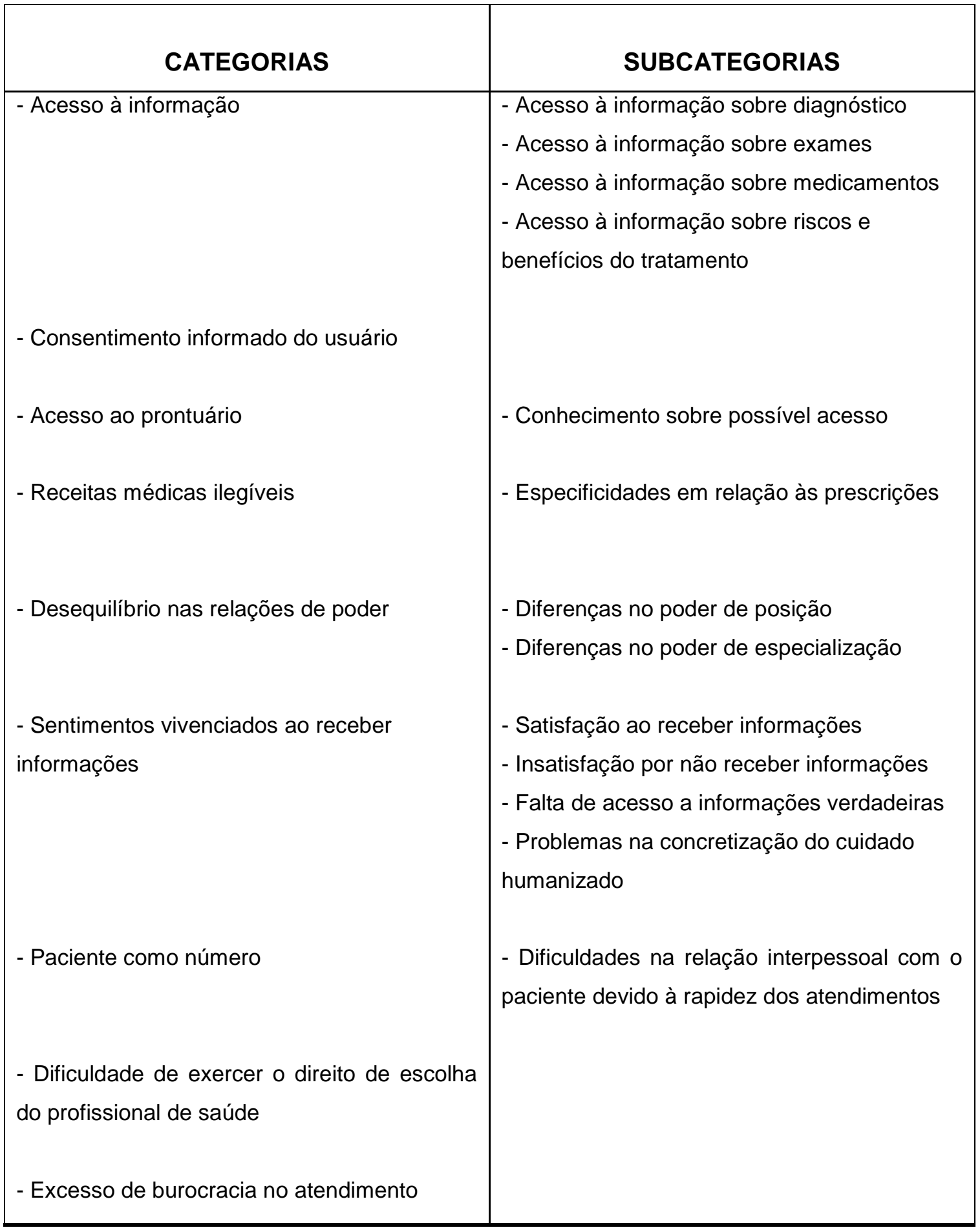

Quadro 2 - Categorias e subcategorias resultantes da sistematização. 
4 O USUÁRIO DO SUS E O CONHECIMENTO SOBRE O SEU DIREITO À INFORMAÇÃO: RESULTADOS E DISCUSSÃO 


\subsection{Perfil dos sujeitos da pesquisa}

Os dados coletados são expostos a seguir. Inicialmente, apresentam-se os dados sócio-demográficos a fim de caracterizar o perfil dos pesquisados. Em seguida, a partir de cada categoria temática são discutidos os temas levantados pelos respondentes da pesquisa. Neste ponto, ressalta-se que para garantir o sigilo e anonimato das informações, os entrevistados são identificados por uma letra e um algarismo como segue: entrevistado 1 (E1); entrevistado 2 (E2) ou mesmo $(E: 1 ; 2 ; 3 .$.$) , quando houver agrupamento de respostas.$

Tabelas quantitativas foram elaboradas apenas para auxiliar a discussão e sistematização dos dados, uma vez que trata-se de uma pesquisa essencialmente qualitativa.

A partir da tabela dos dados sócio demográficos, observa-se que prevaleceram entrevistados na faixa etária entre 21-30 anos, 5 (22,7\%), e também 61-70 anos, 5 (22,7\%). Outras faixas etárias apareceram em menor número. Foram entrevistadas mais mulheres, no total de 16 (72,7\%), sendo na maioria respondentes casados 7 (31,8\%) ou divorciados 7 (31,8\%); com a predominância de sujeitos que cursaram apenas o ensino fundamental 10 (45,5\%), seguidos de 7 (31,8\%) com ensino médio completo.

Quanto à profissão, 6 (27,3\%) eram aposentados, seguidos de 3 (13,6\%) respondentes do lar. Ressalta-se que a maioria $17(77,3 \%)$ dos sujeitos têm renda entre 1-3 salários mínimos e já utilizaram o serviço mais de seis vezes 14 (63,7\%). 
Tabela 1 - Características dos usuários entrevistados segundo idade, sexo, estado civil, escolaridade, profissão, renda e utilização do serviço.

\begin{tabular}{|c|c|c|}
\hline CARACTERÍSTICAS & No & $\%$ \\
\hline \multicolumn{3}{|l|}{ IDADE } \\
\hline $21-30$ & 5 & 22,7 \\
\hline $31-40$ & 3 & 13,7 \\
\hline $41-50$ & 4 & 18 \\
\hline $51-60$ & 3 & 13,7 \\
\hline $61-70$ & 5 & 22,7 \\
\hline $71-80$ & 1 & 4,5 \\
\hline $81-90$ & 1 & 4,5 \\
\hline \multicolumn{3}{|l|}{ SEXO } \\
\hline feminino & 16 & 72,7 \\
\hline masculino & 6 & 27,3 \\
\hline \multicolumn{3}{|l|}{ ESTADO CIVIL } \\
\hline solteiro & 5 & 22,7 \\
\hline casado & 7 & 31,8 \\
\hline união estável & 1 & 4,5 \\
\hline viúvo & 2 & 9 \\
\hline divorciado & 7 & 31,8 \\
\hline \multicolumn{3}{|l|}{ ESCOLARIDADE } \\
\hline analfabeto & 1 & 4,5 \\
\hline ensino fundamental & 10 & 45,5 \\
\hline ensino médio & 7 & 31,8 \\
\hline superior & 2 & 9 \\
\hline superior incompleto & 2 & 9 \\
\hline \multicolumn{3}{|l|}{ PROFISSÃO } \\
\hline aposentado & 6 & 27,3 \\
\hline auxiliar administrativo & 2 & 9 \\
\hline auxiliar de enfermagem & 1 & 4,5 \\
\hline auxiliar de estoque & 1 & 4,5 \\
\hline costureira & 2 & 9 \\
\hline do lar & 3 & 13,7 \\
\hline doméstica & 1 & 4,5 \\
\hline eletricista & 1 & 4,5 \\
\hline mecânico & 1 & 4,5 \\
\hline porteiro & 1 & 4,5 \\
\hline professora & 1 & 4,5 \\
\hline químico & 1 & 4,5 \\
\hline salgadeira & 1 & 4,5 \\
\hline \multicolumn{3}{|l|}{ RENDA } \\
\hline 1-3 salários mínimos & 17 & 77,3 \\
\hline 3-5 salários mínimos & 4 & 18 \\
\hline 5-7 salários mínimos & 1 & 4,5 \\
\hline \multicolumn{3}{|l|}{ UTILIZAÇÃO DO SERVIÇO } \\
\hline $1-3$ vezes & 7 & 31,8 \\
\hline $4-6$ vezes & 1 & 4,5 \\
\hline mais de 6 vezes & 14 & 63,7 \\
\hline
\end{tabular}




\subsection{Categorias e subcategorias temáticas}

\subsubsection{Acesso à informação}

Discute-se nesta categoria temática o acesso ou mesmo a falta de acesso à informação referente à saúde de acordo com as declarações dos respondentes da pesquisa. No âmbito do acesso à informação, são analisados recebimentos de informações sobre diagnóstico; recebimento de informações sobre exames; recebimento de informações sobre medicamentos e recebimento de informações sobre riscos e benefícios do tratamento.

Nesse sentido, Biondo-Simões et al. (2007) evidenciam que as informações devem ser prestadas de acordo com a personalidade, o grau de conhecimento e as condições clínicas e psíquicas do paciente, deixando claros dados do diagnóstico ao prognóstico, dos tratamentos a efetuar, dos riscos e benefícios e alternativas, se existirem. Quanto à forma de fornecimento das informações, dizem ainda que podem ser oral ou por escrito, desde que haja certeza da compreensão dos dados. Os autores corroboram, portanto, a importância do padrão subjetivo da comunicação em saúde.

Ressalta-se, assim, que quanto mais informações forem disponibilizadas aos pacientes, maior será seu poder de decisão e participação nas decisões que dizem respeito à sua saúde, sendo fundamental reconhecer o usuário como um cidadão, sujeito de sua própria vontade e do seu próprio cuidado (CHAVES; COSTA; LUNARDI, 2005).

Desse modo, analisa-se o acesso à informação a partir das 4 subcategorias seguintes: 


\subsubsection{Acesso à informação sobre diagnóstico}

A Portaria do Ministério da Saúde nº 1286 de 26 de outubro de 1993 em seus arts. $8^{\circ}$ e 74 , esclarece que:

"O paciente tem direito a ter seu diagnóstico e tratamento por escrito, identificado com o nome do profissional de saúde e seu registro no respectivo Conselho Profissional, de forma clara e legível" (BRASIL, 1993). Na tabela abaixo, apresentam-se os resultados sobre o acesso a informações relacionadas ao diagnóstico a partir das respostas obtidas nas entrevistas.

Tabela 2 - Recebimento de informações sobre diagnóstico.

\begin{tabular}{llc}
\hline $\begin{array}{l}\text { Informações sobre } \\
\text { diagnóstico }\end{array}$ & \multicolumn{1}{c}{ Pacientes } \\
\hline Sim & $\mathrm{E}: 6 ; 7 ; 10 ; 12 ; 14 ; 15 ; 16 ; 18 ;$ \\
& $21 ; 22$ & 45,5 \\
Não & $\mathrm{E}: 1 ; 2 ; 8 ; 9 ; 11 ; 13 ; 17 ; 20$ & 36,4 \\
Não soube responder & $\mathrm{E}: 3 ; 4 ; 5 ; 19$ & 18
\end{tabular}

Fonte: Tabela elaborada pela autora de acordo com dados das falas dos respondentes da pesquisa.

Ao serem perguntados sobre o recebimento de informações sobre o diagnóstico, $10(45,5 \%)$ dos entrevistados responderam que sim, que receberam informações sobre o diagnóstico da doença. Observa-se este episódio nas falas:

"Eu recebo uma boa informação, eu sou muito espicula né bem, eu fico questionando muito então sabe toda dúvida que eu tenho eu vou perguntar, então eu tenho boa informação" (E6).

"Bom, eu trato muito nas clínicas porque eu sou cardiopata, então lá eles me dão todas as informações, todas. $\mathrm{E}$ quando eu venho no postinho também, quando eu vou no postinho do São José, que é meu bairro, quando eu venho aqui, eles me informam tudo que eu quero saber, não tenho queixa não" (E10).

"...fala se é, normalmente fala que é virose, que nem: eu tô com suspeita de dengue, mas ela não falou nada ontem, só falou que é suspeita” (E14). 
"Todas essas informações que você falou. Que nem agora eu tô, eu fiz o exame de dengue eu tô indo com ele pra ver qual é o resultado, que que deu, se eu tenho que tomar alguma medicação, se eu não tenho, os sintomas... que eu também não tô sentindo muito bem eu vou passar com ele de novo pra ver o que é que ele fala" (E15).

Um usuário disse que não recebe informação, somente o diagnóstico:

"Nenhuma. Eles não informam, não informam nada, aqui a gente é...a hora que você chega pra ser atendido eles te dá o diagnóstico e pronto, acabou, e você vai embora" (E12).

Outros 8 (36,4\%) responderam que não foram informados sobre 0 diagnóstico, o que pode ser exemplificado no depoimento:

\begin{abstract}
"Por exemplo, o dia que eu vim na consulta a médica eu pedi pra médica um raio $x$ e ela falou que não tinha necessidade, eu caí há pouco tempo e fiquei paralisada e ela falou que não que não precisava. $E$ ela explicou por quê? Ela falou que não, que se eu tivesse quebrado eu não tava conseguindo andar, foi o que ela me respondeu e eu tô aqui de volta desde o dia 23, tô aqui de volta e passou injeção, tomei os dias todos mas a dor vai a dor vem" (E1).
\end{abstract}

Neste depoimento observa-se que a médica não diagnosticou a usuária do serviço, apenas disse que se tivesse quebrado a perna, não estaria andando. Não explicou à paciente a razão do tratamento.

Outra paciente adverte que não teve informações:

\begin{abstract}
"Eu nunca tive, inclusive eu vim aqui... é... domingo e eu tava com 39 e pouco de febre, voltei pra casa e fiquei ruim a semana inteira, sexta-feira que eu vim aqui que eu falei que tava com dengue, eu vim aqui e eu tô morando lá onde tem o foco da dengue e ninguém descobriu que eu tava com a dengue. Eu tive que voltar aqui e falar que eu tava com dengue. Então a senhora recebeu alguma informação sobre o seu diagnóstico? Não, fizeram uns tipo de exame, falaram que eu tava com outra coisa, aí o exame deu negativo. Eu voltei pra casa passando mal tudo, na sexta-feira que eu voltei aqui e falei: eu moro lá no foco da dengue e não me pediram exame nem nada, foi aí que o médico pediu exame(de dengue)" (E2).
\end{abstract}

No depoimento acima, a paciente diz que não recebeu o diagnóstico e que precisou dizer que morava no foco da doença para que pedissem um exame.

Ainda, 4 (18\%) sujeitos da pesquisa não souberam responder se receberam diagnóstico ou não, ou seja, verifica-se que em alguns casos, os usuários não 
sabiam o que era diagnóstico ou o seu significado. Evidencia-se, então, a falta de conhecimento acerca de assuntos relacionados à saúde, uma vez que perguntados sobre o recebimento de informações sobre diagnóstico, não souberam responder a essa pergunta, mesmo depois da explicação do que era o diagnóstico pela pesquisadora. Nesses momentos, é ainda mais importante o papel do sujeito mediador, que se predispõe, com base em um padrão subjetivo, alternado de acordo com as características do interlocutor, a realmente mediar esta informação, garantindo que seja compreendida pelo usuário do serviço de saúde.

\subsubsection{Acesso à informação sobre exames}

Em relação aos exames, o paciente tem direito a receber explicações claras e para qual finalidade será coletado o material para exame de laboratório (BRASIL, 1993; SÃO PAULO, 1999). As informações obtidas na pesquisa são detalhadas na tabela 3.

Tabela 3 - Recebimento de informações sobre exames.

\begin{tabular}{ll}
\hline $\begin{array}{l}\text { Informações sobre } \\
\text { diagnóstico }\end{array}$ & Pacientes \\
\hline Sim & $\mathrm{E}: 1 ; 2 ; 3 ; 6 ; 7 ; 8 ; 10 ; 12 ; 15 ;$ \\
& $16 ; 18 ; 19 ; 20 ; 21$ \\
Não & $\mathrm{E}: 9 ; 11 ; 13 ; 14 ; 17 ; 22$ \\
Não fez exame & $\mathrm{E}: 4 ; 5$
\end{tabular}

Fonte: Tabela elaborada pela autora de acordo com dados das falas dos respondentes da pesquisa.

Observa-se que $14(63,7 \%)$ entrevistados obtiveram informações sobre os exames realizados. 
"A não ser assim, se for algum, como eu já fiz assim, exame de urina pra ver se eu tinha alguma infecção, assim, só esse tipo de explicação" (E12).

"Que nem agora eu tô, eu fiz o exame de dengue eu tô indo com ele pra ver qual é o resultado, o que que deu, se eu tenho que tomar alguma medicação, se eu não tenho, os sintomas que eu também não tô sentindo muito bem eu vou passar com ele de novo pra ver o que é que ele fala" (E15).

Contudo, $6(27,3 \%)$ respondentes disseram que não foram informados sobre os exames realizados:

"...às vezes faz o pedido de exame mas informações mesmo são raras, quase ninguém dá, somente se for o médico, porque profissional na área de saúde nenhum"(E9).

"Olha às vezes eu acho assim, a informação não é muito bem dada, entendeu? Às vezes falta alguma coisa, às vezes até a gente fica meio em dúvida né, de alguma coisa, então eu acho assim, que os médicos precisavam realmente dar mais detalhes pra gente, a gente fica até meio, até meio em dúvida quanto a exame, eles falam que tá tudo bem mas não fala o que... é... hã... quantidade por exemplo assim, de o que deu no exame, o que não deu, eles só falam assim: você não tem nada! É isso que eles falam pra gente né, assim, eles procuram ser o mais objetivo possível mas pra gente isso não é bom né, a gente também quer saber mais da nossa saúde" (E11).

“...principalmente de resultado de exame, normalmente é bem resumido..."(E13).

É importante notar nesses depoimentos que os pacientes necessitam de informações mais claras sobre os resultados dos exames, uma vez que se queixam que as informações "não são muito bem dadas" ou são "muito resumidas". Nesse contexto, a objetividade do médico ao dizer que "o paciente não tem nada", pode se dever ao fato do médico acreditar que essa é uma informação suficiente ao paciente, como também pode demonstrar uma atitude paternalista.

Outros $2(9 \%)$ sujeitos da pesquisa responderam que não fizeram exame.

"Mais o que eu peguei é remédio, exame eu também não fiz, aí os remédios que passaram é explicado o porque" (E4).

"No meu caso tá sendo a primeira vez... não fiz exame ainda" (E5). 


\subsubsection{Acesso à informação sobre medicamentos}

Receber informações sobre medicamentos é de fundamental importância em virtude da seriedade dos seus efeitos colaterais, com ou sem a junção com outros tipos de medicamentos que a pessoa já utilize. Nesse sentido, o recebimento de informações sobre medicamentos é discutido com base nos dados da tabela 4 .

Tabela 4 - Recebimento de informações sobre medicamentos.

\begin{tabular}{llc}
\hline $\begin{array}{l}\text { Informações sobre } \\
\text { medicamentos }\end{array}$ & \multicolumn{1}{c}{ Pacientes } \\
\hline Sim & $\mathrm{E}: 1 ; 4 ; 6 ; 10 ; 14 ; 16 ; 18 ; 21$ & 36,4 \\
Não & $\mathrm{E}: 3 ; 9 ; 11 ; 12 ; 17 ; 19 ; 20 ; 22$ & 36,4 \\
Só se o paciente perguntar & $\mathrm{E}: 7$ & 4,5 \\
Não responderam & $\mathrm{E}: 2 ; 5 ; 8 ; 13 ; 15$ & 22,7
\end{tabular}

Fonte: Tabela elaborada pela autora de acordo com dados das falas dos respondentes da pesquisa.

Constata-se que $8(36,4 \%)$ dos pacientes responderam que receberam informações sobre medicamentos.

"...aí os remédios que passaram foi explicado o porquê. Os efeitos colaterais... isso é explicado" (E4).

"...falou pra mim tomar soro, em casa e se ficasse ruim voltar, aí foi o que aconteceu, voltei" (E14).

"Sobre os efeitos colaterais dos medicamentos eles avisam? Ah sim, eles avisam. No meu caso, no meu caso que eu tenho acidente de trabalho, por exemplo, eu se eu não usar o medicamento eu não mexo as mãos eu não ando eu travo, então ele fala que eu vou ter que ficar pro resto da vida dependente" (E21).

Em contrapartida, $8(36,4 \%)$ respondentes não receberam informações sobre medicamentos como segue:

"Poucas informações viu, normalmente a gente sempre recebe poucas informações" (E13). 
"E efeito colateral dos medicamentos, eles falam alguma coisa? A senhora toma bastante remédio que a senhora me mostrou, e os médicos quando foram passar pra senhora eles falaram se tem algum efeito colateral esses medicamentos? Não, não falô nada não, não falô nada" (E17).

"A senhora tem esse tipo de informação sobre os medicamentos que toma? Esse remédio da tiróide eu não tenho" (E17).

Dentre esses, o respondente (E3) diz que não recebeu essa informação porque não teve problema nenhum.

"Não, não, porque eu não tive nada, eu não tive problema nenhum" (E3).

Já o usuário (E7) diz que só recebe informação se perguntar:

\begin{abstract}
"As informações básicas mesmo né, é... quanto ao, ao, ao, como é que fala? Efeito colateral, isso se a gente perguntar eles respondem, senão, não interessa aí a gente que é interessada, no meu caso que eu tenho alergia aí eu pergunto, caso contrário, acho que quase ninguém faz essa pergunta né" (E7).
\end{abstract}

Nessa perspectiva, a Carta dos Direitos dos Usuários da Saúde (BRASIL, 2006) explica que todo cidadão deve se comprometer a prestar informações apropriadas nos atendimentos, nas consultas e nas internações sobre queixas, enfermidades e hospitalizações anteriores, história de uso de medicamentos e/ou drogas, reações alérgicas e demais indicadores de sua situação de saúde.

Ainda, 5 (22,7\%) entrevistados não responderam à pergunta, pois não tinham informações claras sobre os medicamentos prescritos e seus efeitos.

\title{
4.2.1.4 Acesso à informação sobre os riscos e benefícios do tratamento
}

Os riscos e benefícios do tratamento realizado somam importante fator a se considerar sobre a informação recebida pelo paciente. Nesse contexto, Coelho et al. (2008) e Culver (2002) afirmam que o usuário deve receber do profissional informações adequadas sobre o tratamento sugerido, incluindo os possíveis danos, inconvenientes. Devem ser informados sobre as alterações de dor, sofrimento e 
condições patológicas, além dos benefícios associados com qualquer outro tratamento que possa ser utilizado. Precisam ser explicadas as informações sobre os procedimentos, os objetivos diagnósticos e/ou terapêuticos, as alternativas de tratamento e o prognóstico. A relação custo-benefício também deve ser considerada. Estes dados são descritos na tabela 5.

Tabela 5 - Recebimento de informações sobre riscos e benefícios do tratamento.

\begin{tabular}{lll}
\hline $\begin{array}{l}\text { Informações sobre riscos } e \\
\text { benefícios do tratamento }\end{array}$ & \multicolumn{1}{c}{ Pacientes } \\
\hline Sim & $\mathrm{E}: 4 ; 6 ; 7 ; 8 ; 10 ; 15 ; 16 ; 17 ; 18 ; 22$ & 45,5 \\
Não & $\mathrm{E}: 1 ; 2 ; 9 ; 11 ; 12 ; 13 ; 14$ & 31,8 \\
Não responderam & $\mathrm{E}: 3 ; 5 ; 19 ; 20 ; 21$ & 22,7
\end{tabular}

Fonte: Tabela elaborada pela autora de acordo com dados das falas dos respondentes da pesquisa.

Sobre os riscos e benefícios do tratamento, observou-se que 10 (45,5\%) dos respondentes disseram que receberam informações sobre benefícios do tratamento.

“...as orientações foram boas" (E4).

“...eles me dão todas as informações, todas" (E10).

"Ah, fala dos benefícios né, de como emagrecer né, eu tenho pressão alta, eu faço uso do remédio para pressão alta, essas coisas" (E8).

Outrossim, sobre riscos apenas $1(4,5 \%)$ usuário relatou ter recebido informação.

"Eles nunca falaram que minhas doença é grave, só fala que eu tenho que fazer o regime, que se num fizer né, a diabete sobe muito".(E17).

Outros $7(31,8 \%)$ pacientes disseram que não receberam informações sobre os riscos e benefícios do tratamento como segue: tomar as injeção, acabou, só isso" (E1). 
"Olha às vezes eu acho assim, a informação não é muito bem dada, entendeu?" (E11).

"Sobre os riscos e benefícios do tratamento da senhora eles falam alguma coisa? Só fala que eu tenho que fazer direitinho conforme tá marcado, cê viu que marcado? Eu pego remédio aqui. Mas não falam quais os benefícios nem os riscos? Não, não. E duração do tratamento, a senhora recebe alguma informação sobre isso? Quanto tempo vai durar? Não" (E17).

Já $5(22,7 \%)$ sujeitos não responderam a essa pergunta. Os respondentes justificaram ser a primeira vez que utilizava o serviço e, por isso, não tinham ainda passado por essa situação de receber informações sobre riscos e benefícios de tratamento.

"No meu caso tá sendo a primeira vez...não tenho nada de muito claro pra te falar" (5).

"É a primeira vez que eu tô, tô consultando aqui" (E20).

Outra situação constatada deve-se ao fato do paciente não ter tido informação, por não ter sido passado tratamento até o momento.

"Não, eu não passei por isso ainda" (E19).

"Não, não é o meu caso" (E21).

E, ainda, um usuário afirmou que não tem problema de saúde, por isso não tem o que falar sobre riscos e benefícios do tratamento.

"Isso eu não posso dizer porque eu não tenho problema nenhum de saúde" (E3).

Diante das subcategorias analisadas depreende-se que os pacientes estão recebendo informações sobre diagnóstico $(45,5 \%)$, exames $(63,7 \%)$, medicamentos $(36,4 \%)$ e riscos e benefícios do tratamento (45,5\%). Contudo, há ainda grande número de pacientes que não recebem esse tipo de informação: pacientes que não receberam informações sobre diagnóstico (36,4\%); sobre exames (27,3\%), sobre medicamentos $(36,4 \%)$ e sobre riscos e benefícios do tratamento $(31,8 \%)$. 
Portanto, considerando-se a informação e o conhecimento como meios que permitem a perpetuação das relações democráticas, a falta de informação, caracterizada como ignorância, permite ações abusivas, de exploração, subjugação e dominação. Enfatiza-se, assim, que para que as pessoas possam cuidar de si e administrar o seu corpo, faz-se necessário manterem-se bem informadas e lutar pelos seus ideais e crenças (GAUDERER, 1998).

Nessa pesquisa, verifica-se um movimento afirmativo que estabelece relações democráticas entre profissional de saúde e paciente, apesar de serem ainda observadas lacunas na comunicação entre profissional de saúde e usuário.

Ao abordarem o tema, Holm (1993), Fortes (1996) e Barros (2000) argumentam que, geralmente, essas informações limitam-se àquelas que os profissionais julgam ser necessárias e suficientes, nem sempre considerando e valorizando o que o paciente gostaria de saber sobre sua doença. Nesse sentido, salientam que a informação sonegada não decorre de má-fé, mas da postura paternalista que prevalece no setor da saúde, com a qual os profissionais têm a intenção de beneficiar o paciente, considerando o temor das conseqüências adversas à sua esfera psicológica.

Outro ponto a ressaltar é que "existem pessoas que não têm consciência de seu direito à informação e que permanecem em uma posição passiva, não questionam e esperam da equipe de saúde a decisão sobre seu cuidado e tratamento" (CARMO, 2002, p.10).

Essa posição passiva em relação ao recebimento de informações dificulta 0 empoderamento da informação pelo usuário, impedindo que as relações democráticas sejam construídas.

\subsubsection{Consentimento esclarecido do usuário}

A partir das respostas dos usuários entrevistados, observa-se ainda grande lacuna quanto ao ato de consentir ou recusar procedimentos em relação à sua saúde. Dos $22(100 \%)$ respondentes, apenas $5(22,7 \%)$ foram consultados se consentiam com o procedimento realizado.

Os dados podem ser observados na tabela 6: 
Tabela 6 - Consentimento esclarecido do usuário quanto à procedimentos relacionados à sua saúde.

\begin{tabular}{lll}
\hline $\begin{array}{l}\text { Paciente perguntado sobre } \\
\text { consentimento }\end{array}$ & \multicolumn{1}{c}{ Pacientes } \\
\hline Sim & $\mathrm{E}: 5 ; 6 ; 9 ; 10 ; 18$ & 22,7 \\
Não & $\mathrm{E}: 1,2 ; 3 ; 4 ; 7 ; 8 ; 11 ; 12 ; 13 ; 14 ; 15 ;$ & 77,3 \\
& $16 ; 17 ; 19 ; 20 ; 21 ; 22$ & \\
\hline
\end{tabular}

Fonte: Tabela elaborada pela autora de acordo com dados das falas dos respondentes da pesquisa.

A maioria dos que responderam que foram consultados, disseram que acham importante a consulta ao paciente antes da realização de procedimentos, porém não explicam o porquê:

"Pergunta. Pergunta" (E5).

"Como é a pergunta? Eles perguntaram se a senhora consentiria ou recusaria o tratamento ou algum procedimento que tivesse que ser realizado? Sim. E a senhora acha essa pergunta importante? Eu acho"(E9).

"Ah pergunta né. E a senhora acha essa pergunta importante? Eu acho" (E10).

Já os respondentes $(E: 6 ; 18)$ argumentam a razão da importância do consentimento.

"Se eles me perguntam? É, se a senhora consentiria ou recusaria o tratamento? Sim, mas eu nunca recuso né, porque toda vez que eu venho eu estou com grande necessidade, como agora né" (E6).

"Perguntou sim, foi perguntado, inclusive em cima de exames feitos né [...] Isso é importante sim, porque uma pessoa pra fazer uma cirurgia, um tratamento, pra tomar um medicamento que às vezes é contrário a alguma coisa que ele possa estar sentindo, pode causar um problema pra ele" (E18).

Diante da relevância ressaltada pelos respondentes, Cohen e Marcolino (2002) explicitam que a essência do princípio da autonomia é o consentimento esclarecido. Este deve ser emitido pelo indivíduo quando de atos que afetem sua integridade físico-psíquica. Os autores acrescentam ainda que precisa existir, por parte do profissional, a "informação livre e esclarecida", propiciando ao paciente 
condições de exercer uma relação de igualdade e liberdade, buscando uma relação mais justa, mais equânime e mais humana.

O consentimento livre e esclarecido é uma condição indispensável da relação profissional-paciente. Trata-se de uma decisão voluntária, realizada por uma pessoa autônoma e capaz, tomada após um processo informativo e deliberativo, visando à aceitação de um tratamento específico ou experimentação, sabendo da sua natureza, das suas conseqüências e dos seus riscos (SAUNDERS; BAUM; HOUGHTON, 1994).

O exercício do consentimento envolve uma relação humana dialogante, no caso uma comunicação, o que deveria eliminar atitudes arbitrárias ou prepotentes por parte do profissional da saúde. Este posicionamento manifesta o reconhecimento do usuário como um ser autônomo, livre e merecedor de respeito (CLOTET, 1995).

Portanto, "não se considera como informação esclarecedora aquela dada por meio da utilização de instrumentos e impressos previamente elaborados sem a posterior verificação de seu entendimento" (CARMO, 2002, p. 11). Observa-se que ocorre em muitas instituições o fato de terem um impresso "pronto" e pedirem para o paciente assinar, sem ao menos explicar do que se trata o documento. O paciente, que já está fragilizado pela doença, muitas vezes não sabe ao menos o que está assinando.

Deve-se enfatizar que neste estudo, os usuários (E: $1,2 ; 3 ; 4 ; 7 ; 8 ; 11 ; 12 ; 13 ; 14 ; 15 ; 16 ; 17 ; 19 ; 20 ; 21 ; 22)$, ou seja 17 (77,3\%) disseram que não foram consultados sobre procedimentos realizados e nem tiveram a informação sobre o termo de consentimento livre e esclarecido.

Fortes (1994) e Carmo (2002) ressaltam que o paciente tem a livre escolha e a liberdade de não querer ser informado acerca de seu tratamento, ou ainda tem a possibilidade de solicitar que as informações sejam dadas a terceiros ou também se podem emitir seu consentimento sem receber determinadas informações. Coelho (2000) acrescenta que o consentimento pode ser repassado a terceiros quando se tratar de incapacidade física ou mental e nos casos de menor de idade.

Para que haja um consentimento esclarecido, a informação revelada deve ser compreendida, não sendo suficiente que a pessoa seja mera receptora. Informações falseadas, incompletas ou mal-entendidas podem ocasionar defeitos de raciocínio, por meio dos quais os indivíduos formam suas opiniões baseados em fatos 
manifestamente implausíveis e comprometem sua decisão autônoma (FORTES, 1994).

Nesse sentido, buscou-se compreender as razões consideradas pelos pacientes para a existência desta lacuna na informação. Ao serem perguntados o porquê não foi feita a pergunta se o paciente consentia ou recusaria o tratamento, um dos entrevistados argumentou:

"Não sei, as vezes é por falta de, de..., de... informação da gente mesmo né, quais os direitos da gente, a gente não tem" (E16).

No que diz respeito aos direitos, Kreischer et al. (1996) consideram o desconhecimento ou desrespeito aos direitos do paciente como prováveis causas de grande parte dos problemas que ocasionam a atual crise assistencial. Esse desconhecimento ou desrespeito é atribuído tanto à equipe médica como também à de enfermagem que não conhecem e/ou não atendem/respeitam os direitos do usuário. Já os pacientes, na maioria das vezes, não os exigem por simplesmente desconhecê-los.

Assim, a "educação mostra-se como uma possibilidade de acesso à informação e consciência política em direção a uma mudança nas práticas de saúde que ferem a dignidade humana" (GOMES et al. 2008, p. 774).

O paciente tem a idéia de que como o serviço é oferecido gratuitamente, o que for realizado é tido como bom. Dessa forma, não questiona e fica esperando que os médicos decidam sobre sua saúde e ou doença. Não reivindicam seus direitos, ou não sabem que podem reivindicá-los. Os depoimentos $(E: 7 ; 12)$ elucidam esta afirmação:

\footnotetext{
"Porque eu acho que quando você vem pra cá, você já vem pronta, se você vem no posto é porque você está doente, você está pronto pra fazer qualquer exame pra saber o resultado e o porquê você está doente" (E7).

"Porque eu acho que o que vier tá bom pra gente né aqui, eu acho, eu entendo assim, eu entendo que eles não dão explicação nenhuma, eles não te perguntam nada" (E12).
}

Há também os pacientes que culpam o atendimento ou o médico: 
"Ah, não sei, acho que é pelo atendimento precário né" (E14).

A partir dos dados coletados, observa-se o desconhecimento da grande maioria dos entrevistados sobre o seu consentimento esclarecido.

\subsubsection{Acesso ao prontuário}

O Conselho Federal de Medicina define o prontuário como "um conjunto de documentos padronizados e ordenados, destinados ao registro dos cuidados profissionais prestados ao paciente pelos serviços de saúde pública ou privada" (CFM, 2002). Deve conter o histórico do paciente, princípio e evolução da doença, raciocínio clínico, exames, conduta terapêutica e demais relatórios e anotações clínicas (BRASIL, 1993).

Para Bittar (1980), o prontuário representa uma forma de contrato, sendo o instrumento de ligação entre os profissionais e o usuário, de valor legal e jurídico e com implicações como tal.

O prontuário, historicamente denominado como do médico e atualmente como do paciente, é o documento em que devem estar registrados todos os episódios de atendimento ao usuário no serviço, de qualquer natureza e tipo de profissional de saúde (BECHARA, 2003). É, também, um elemento crucial no atendimento à saúde dos indivíduos, devendo reunir a informação necessária para garantir a continuidade dos tratamentos prestados ao usuário (MARIN; MASSAD; AZEVEDO NETO, 2003).

Dessa forma, a tabela 7 evidencia o acesso ao prontuário pelos respondentes da pesquisa.

Tabela 7 - Acesso ao prontuário.

\begin{tabular}{llc}
\hline Acesso ao prontuário & \multicolumn{1}{c}{ Pacientes } & $\%$ \\
\hline Sim & $--10-0$ & ---- \\
Não & E:1;2;3;4;5;6;7;8;9;10;11;12;13;14;15; & 100 \\
& $16 ; 17 ; 18 ; 19 ; 20 ; 21 ; 22$ &
\end{tabular}

Fonte: Tabela elaborada pela autora de acordo com dados das falas dos respondentes da pesquisa 
Ao serem perguntados sobre o acesso ao prontuário, todos os pacientes, 22 (100\%), responderam que nunca tiveram acesso físico ao seu prontuário:

"Não" (E: 1;2;3;4;5;6;8;9;11;12;13;14;15;16;19;20;22).

"Não, nunca me informei" (E7).

"É que por essa lei que eu estava falando pra senhora, a senhora tem direito a pedir uma cópia do prontuário caso precise de mudar de médico, ou até pra levar na UNAERP... Ah... sei... A senhora tem direito à isso, então a senhora já usou esse direito alguma vez? Não" (E17).

"E o senhor já teve acesso? Não, nunca precisei" (E18).

\subsubsection{Conhecimento sobre possível acesso ao prontuário}

Ainda quanto a esta possibilidade de acesso, os usuários foram perguntados se sabiam que poderiam ver, ou seja ter acesso físico a esta documentação. Mais uma vez, a maioria dos entrevistados 20 (91\%), além de não terem tido acesso ao prontuário, acreditam que não podem ter este acesso.

Tabela 8 - Conhecimento sobre possível acesso ao prontuário.

\begin{tabular}{lll}
\hline $\begin{array}{l}\text { Conhecimento sobre possível } \\
\text { acesso ao prontuário }\end{array}$ & \multicolumn{1}{c}{ Pacientes } \\
\hline Sim & $\mathrm{E}: 10 ; 13$ & 9 \\
$\mathrm{Não}$ & $\mathrm{E}: 1 ; 2 ; 3 ; 4 ; 5 ; 6 ; 7 ; 8 ; 9 ; 11 ; 12 ; 14 ; 15 ;$ & 91 \\
& $16 ; 17 ; 18 ; 19 ; 20 ; 21 ; 22$ &
\end{tabular}

Fonte: Tabela elaborada pela autora de acordo com dados das falas dos respondentes da pesquisa.

Apenas $2(9 \%)$ sabem ou acreditam que podem ter acesso ao seu prontuário médico: 
Nota-se, entretanto, que mesmo o paciente que disse que tinha a possibilidade de acesso apresentou dúvidas se, na prática, isso realmente pode acontecer. O Art. 88 do Código de Ética Médica diz que o médico não pode negar ao paciente acesso a seu prontuário, ou deixar de lhe fornecer cópia quando solicitada, bem como deixar de lhe dar explicações necessárias à sua compreensão, salvo quando ocasionarem riscos ao próprio paciente ou a terceiros (CFM, 2009). Contudo, o desconhecimento deste fato é recorrente nas falas dos usuários do serviço estudado:

\footnotetext{
"Pera aí bem, como é que é? A senhora sabe se a senhora pode ter acesso ao prontuário médico? Alí? Se eu posso chegar e pedir? É. Não, é só através de uma enfermeira, e através de um pedido... já marcado a consulta, a moça, a enfermeira, a auxiliar né, como é a palavra certa, a profissional né, ela vai buscar e aí o médico passa, eu aqui nunca tive e nem peço. Não, não. Se eu chegar no balcão e pedir e eles me entregarem nunca, nem, nem... E a senhora sabe se pode? Bem... eu não sei, mas eu acredito que não" (E6).
}

"Não"; "Nunca me interessei, nunca me informei"; "Não sei" (E: $1 ; 2 ; 3 ; 4 ; 5 ; 6 ; 7 ; 8 ; 9 ; 11 ; 12 ; 14 ; 15 ; 16 ; 17 ; 18 ; 19 ; 20 ; 21 ; 22)$.

"Não. Eu posso pedir? É. Por que cê queria ver? Não, eu só queria saber se a senhora sabe se pode ter... Eu tenho minha pasta aí. Então, mas a senhora sabe se a senhora pode ter acesso a ela? Não, não sei, quando eu vô consurtá, eles já manda minha pasta pra lá. Eles me chama eu pra pesá, pra vê como eu tô né e despois o médico me chama pra consultá. É assim" (E17).

O prontuário reúne os dados fornecidos pelo paciente ou seu responsável legal e os resultados obtidos em qualquer tipo de exame. Trata-se, portanto, de um documento de extrema relevância que visa, acima de tudo, demonstrar a evolução da pessoa assistida e, subseqüentemente, direcionar o melhor procedimento terapêutico ou de reabilitação, além de assinalar todas as medidas associadas e a ampla variabilidade de cuidados preventivos adotados pelos profissionais de saúde (CARVALHO et al. 2008).

O registro das informações dos pacientes nos prontuários é tarefa e dever dos profissionais da área de saúde. Damasceno (2006) refere que "um prontuário médico bem escrito começa com uma história clínica adequadamente feita, com boa observação, anamnese e bom senso, acompanhado de clareza, coerência e concisão". Afirma, ainda, que o prontuário médico deve ser sempre preenchido com 
muita disciplina, pois uma ficha médica bem detalhada e escrita pode ser a única defesa do médico no caso de um processo médico-legal.

Nessa perspectiva, o prontuário guarda as informações a respeito da saúde do usuário do serviço. O prontuário do paciente possui as seguintes finalidades: avaliação dos procedimentos implementados; instrumento de defesa legal, ficha de contabilização econômico-financeira para cobrança de honorários profissionais e serviços prestados e levantamento de casuística para pesquisa e ensino (BECHARA, 2003; MARIN; MASSAD; AZEVEDO NETO, 2003; PEREIRA FILHO; CARNEIRO; MACHADO, 2000).

A falta de anotações e falhas no preenchimento deste documento deixa o médico indefeso em casos de acusações por ausência de orientação, falha no atendimento médico ou negligência, dificultando a defesa profissional. A complicação médico-legal pode resultar num prejuízo para o médico de natureza moral e/ou material. Moral, pois abala a imagem do médico perante a comunidade, denigre sua reputação e diminui sua auto-estima. Material, pois implica perda econômica direta, como na obrigatoriedade de pagamento de honorários advocatícios, de custas processuais e de consultorias técnicas, entre outras. Portanto, deve-se anotar todas as ocorrências com objetividade e clareza, sempre com a identificação pessoal, assinatura e carimbo, contendo o nome do profissional e seu registro profissional (CARVALHO et al., 2008; SPIRI; BERTI; PEREIRA, 2006).

Para que todas essas finalidades sejam atendidas, o prontuário deve conter dados que contemplem informações sociais do cliente (identificação, situação familiar e social, termos de autorização e responsabilidade), informações médicas (histórico, anamnese, exame físico, exames complementares, relatórios de cirurgia e anestesia, prescrição, evolução clínica e diagnóstico definitivo), e informações da enfermagem (relatório de enfermagem, gráficos ou registros de sinais vitais, prescrição de enfermagem) (ROTTA et al., 2003).

Dessa forma, localmente, ou seja, na instituição onde o paciente está recebendo cuidados, o prontuário representa o mais importante veículo de comunicação entre os membros da equipe de saúde responsável pelo atendimento (MARIN; MASSAD; AZEVEDO NETO, 2003).

Todavia, enfatiza-se a partir dos resultados obtidos na falas dos respondentes que apesar dessa importância, muitos usuários de serviços de saúde não sabem que podem ter acesso a essa documentação relativa à sua saúde, como também 
nunca tiveram esse acesso físico. Ainda quanto ao prontuário, o paciente tem o direito de tê-lo elaborado de forma legível (BRASIL, 1993; SÃO PAULO, 1999), bem como as receitas médicas.

\subsubsection{Receitas médicas ilegíveis}

A receita médica é uma importante ferramenta na comunicação entre médico e paciente. Nela são registradas informações valiosas sobre o tratamento, bem como outras orientações (SANO et al., 2002). A legibilidade desta receita é um dos pontos mais importantes no que se refere às prescrições, uma vez que o paciente necessita da receita legível para seguir corretamente a indicação do médico.

Nesse contexto, ressalta-se que 0 paciente tem 0 direito de receber as receitas com o nome genérico do medicamento de acordo com a Lei oํ 9.787/99 e não em código, datilografadas ou em letras de forma, ou com caligrafia perfeitamente legível, com assinatura e carimbo do profissional contendo o número do registro do respectivo Conselho Profissional (BRASIL, 1993, 1999; SÃO PAULO, 1999).

A importância da correta compreensão da receita médica é indiscutível, sendo que ela corresponde ao guia a ser seguido para 0 tratamento do paciente (DEMANTHÉ; CUNHA, 2008).

A tabela 9 ilustra as respostas dos entrevistados quanto à legibilidade das receitas médicas.

Tabela 9 - Acesso às receitas legíveis pelo paciente.

\begin{tabular}{lll}
\hline Receitas legíveis & Pacientes & $\%$ \\
\hline Sim & $\mathrm{E}: 5 ; 6 ; 8 ; 11 ; 17 ; 18$ & 27,3 \\
\multirow{2}{*}{ Não } & $\mathrm{E}: 2 ; 3 ; 4 ; 7 ; 10 ; 12 ; 13 ; 14 ; 15 ;$ & 63,7 \\
& $16 ; 19 ; 20 ; 21 ; 22$ & \\
Ás vezes & $\mathrm{E}: 1 ; 9$ & 9
\end{tabular}

Fonte: Tabela elaborada pela autora de acordo com dados das falas dos respondentes da pesquisa. 
Nota-se, portanto, que a maioria dos entrevistados, ou seja, 14 (63,7\%) disseram que têm dificuldade de entender as receitas, conforme explicitado nas falas:

\author{
“Algumas né, muito difícil” (E2). \\ “Não, e nem é só na rede pública, em lugar nenhum” (E4).
}

"Mas, antes dessas do computador, as outras receitas manuais eram fáceis de ler? Não, tinha coisa que a gente não conseguia ler" (E10).

O entrave na compreensão das receitas médicas deve-se, em muitos casos, às letras dos médicos ressaltadas nas falas:

“Não, isso é difícil. Receita dos médicos, a letra dos médicos né” (E3).

"Raramente não né, raramente alguma coisa você não entende, porque letra de médico é... complicada né" (E18).

"São um garrancho, né? Risos [...] Fácil de ler não é nenhum pouco" (E19).

"Horrível, não, sem dúvida nenhuma, a gente vai lá e a gente pede pros farmacêuticos é... vê porque, porque é horrível. Isso não muda nunca, já foi provado e comprovado: é um garrancho as letras que eles fazem" (E21).

Comprova-se nessa categoria o desrespeito tanto à Lei Estadual 10.241/99, quanto à Portaria do Ministério da Saúde no 1286 de 26 de outubro de 1993 art. 8e e ํo 74, e à Carta dos Direitos dos Usuários da Saúde de 2006, onde se lê que as receitas devem ser digitadas, impressas, datilografadas ou em caligrafia legível.

Sendo assim, em resposta à pergunta sobre legibilidade das receitas médicas, constata-se que os usuários do serviço criticam as receitas ilegíveis, afirmando que isso ocorre não só no serviço público, como também no privado. Ressaltam, ainda, que a letra dos médicos é um fator condicionante para a dificuldade de compreensão das receitas prescritas.e conseqüente acesso cognitivo à essa informação. Corroboram essa idéia Demanthé e Cunha (2008) quando dizem que a prescrição acaba tornando-se rotina para ao médico, o qual a preenche sem 
muitos cuidados relacionados à estética e à facilidade de sua compreensão. $\mathrm{O}$ farmacêutico acaba assumindo o papel de traduzir o que contém a receita.

\subsubsection{Especificidades em relação às prescrições}

Quanto às prescrições e especificidades dos medicamentos, é a partir da consulta que o médico vai decidir sua necessidade e escolher, caso positivo, o melhor medicamento para cada paciente; este vai decidir se seguirá as recomendações feitas de forma integral, parcial ou se não aderirá ao tratamento proposto (PEPE; CASTRO, 2000).

A prescrição feita pelo médico é o resultado de uma série complexa de decisões que este profissional toma durante a consulta, após entrar em contato com o paciente. A importância do prescritor está no fato de ser ele o responsável pela indicação de um medicamento com base na interpretação que faz daquilo que o paciente Ihe diz. A relevância do paciente reside em ser ele quem vai descrever o que está sentindo e quem vai aderir, ou não, à indicação médica. Ambos carregam consigo vivências e expectativas que Ihes permitem tomar decisões quanto à prescrição e uso de determinado medicamento. Neste contato, muitos são os fatores que podem influenciá-los (PEPE; CASTRO, 2000).

O prescritor pode ser influenciado por características pessoais, ou por fatores externos como: local de atendimento, ou seja, um médico de uma Unidade Básica de Saúde, cujo atendimento é gratuito, avalia muito bem antes de prescrever medicamentos que não estejam disponíveis à população e mesmo pondera uma prescrição de um medicamento muito caro, já considerando que o paciente pode não aderir ao tratamento proposto se não tiver condições de comprar o remédio. $O$ prescritor pode ser influenciado também por agências regulamentadoras, propaganda, comunidade acadêmica e interesses econômicos (HIGGINBOTHAM; STREINER, 1991).

Em relação ao paciente, existem características que são da mesma forma importantes para a tomada de decisão médica: as expectativas e demandas dos pacientes, sua família, seus empregadores; a atitude do paciente frente à saúde; suas características físicas como peso, idade, sua sensibilidade aos medicamentos; 
sua condição econômica e inserção no mercado de trabalho (PEPE; TRAVASSOS, 1995).

Sobre essas prescrições e com o intuito de assegurar a oferta de medicamentos de qualidade e baixo custo no mercado, além de fomentar o acesso da população a estes medicamentos, a Lei de Genéricos brasileira (BRASIL, 1999), distingue medicamentos de referência, medicamentos genéricos e medicamentos similares, definindo genéricos como medicamentos que devem, obrigatoriamente, comprovar sua bioequivalência ao medicamento de referência (QUENTAL et al., 2008; MIRANDA et al., 2009). É importante destacar que a Política Nacional de Medicamentos orienta com relação às possibilidades de integração das estratégias de acesso, tais como produção pública, política de genéricos e lista de medicamentos essenciais. Os medicamentos selecionados por critérios de essencialidade integram a Relação Nacional de Medicamentos Essenciais (RENAME), por atenderem às necessidades prioritárias de atenção à saúde do país e deveriam também constituir a base para a produção de genéricos (WHO, 2010; BRASIL, 2006c).

No contexto da prescrição de medicamentos, devem também ser enfatizadas as especificidades dos medicamentos segundo os dados coletados expressos na tabela 10:

Tabela 10 - Especificidades dos medicamentos prescritos.

\begin{tabular}{llc}
\hline Medicamentos genéricos & \multicolumn{1}{c}{ Pacientes } & $\%$ \\
\hline Sim & $\mathrm{E}: 4 ; 5 ; 6 ; 7 ; 8 ; 10 ; 11 ; 12 ; 14 ; 13 ; 15 ;$ & 81,8 \\
& $16 ; 17 ; 18 ; 19 ; 20 ; 21 ; 22$ & \\
Não sabem diferenciar & $\mathrm{E}: 1 ; 2$ & 9 \\
Não toma medicamento & $\mathrm{E}: 3$ & 4,5 \\
Só se o paciente pedir & $\mathrm{E}: 9$ & 4,5 \\
\hline
\end{tabular}

Fonte: Tabela elaborada pela autora de acordo com dados das falas dos respondentes da pesquisa

Quanto aos medicamentos prescritos, $18(81,8 \%)$ entrevistados relataram que recebem as receitas com os nomes genéricos dos medicamentos corroborando com a lei de genéricos nacional. 
Apesar deste esclarecimento e promoção junto aos diversos públicos e farmácias, observa-se, que alguns usuários ainda têm dificuldade de diferenciar o medicamento genérico do medicamento de referência. Para tanto, de forma a facilitar a sua identificação, adotou-se embalagem externa personalizada, criando-se um padrão para as embalagens de todos os medicamentos genéricos comercializados no mercado brasileiro (QUENTAL et al., 2008). Contudo, esta dificuldade pode ainda ser observada nas falas:

"Não, eu não reparei não, normalmente eu pego o remédio normal, ah, eu não sei diferenciar o remédio genérico do outro" (E1).

"Eu pego no postinho né, ele falou que ia me dar esse porque era mais barato, não falou que era genérico" (E2).

Nota-se que $1(4,5 \%)$ respondente diz não tomar medicamento:

“Eu não sei também, porque eu não tomo remédio" (E3).

Ainda, 1 (4,5\%) entrevistado afirma que é receitado medicamento genérico somente se o paciente pedir:

"Às vezes né, quando pede eles passam. Só se pedir? É, só se pedir" (E9).

Mesmo quando não sabe diferenciar os medicamentos, deve-se ressaltar que "o paciente tem direito de receber medicamentos básicos e essenciais, e também medicamentos e equipamentos de alto custo, que mantenham a vida e a saúde" (WHO, 2010; BRASIL, 1993; 2006c). Quanto à possibilidade de acesso aos medicamentos genéricos:

"Geralmente eles tão passando os que fica mais em conta o valor, eles tá passando esses genéricos" (E5).

"São genéricos, muitos eu pego no postinho, quase todos" (E10). 


\footnotetext{
"Alguns eu pego no posto, outros eu compro né, e assim... genérico também porque é mais barato né?" (E18).

"É... genérico, se bem é, depende o valor né, é, eu acredito que as pessoas que não tenha muitas condições de comprar, ou que não tenha no posto, ou dificuldade de achar no posto eles dão o genérico mesmo" (E21).

"Da pressão eu pego no posto né..." (E22).
}

A Política Nacional de Medicamentos determina que os medicamentos essenciais devam estar continuamente disponíveis aos segmentos da sociedade que deles necessitem, nas formas farmacêuticas apropriadas (BRASIL, 1998). Desse modo, os medicamentos constantes na RENAME deveriam estar disponíveis em todo momento no sistema de saúde brasileiro, sobretudo no setor público. A estratégia dos genéricos traduz o compromisso do poder público em promover o acesso aos medicamentos essenciais. Estima-se, então, que o setor público seja um cenário privilegiado para investigar a disponibilidade de genéricos, em especial daqueles considerados essenciais (MIRANDA et al., 2009).

Evidencia-se a partir das falas dos sujeitos da pesquisa que muitos recebem os medicamentos na Unidade Básica de Saúde, em consonância com a proposta da Política Nacional de Medicamentos. Porém, há ainda medicamentos que precisam ser comprados pelos pacientes que optam por adquirir o medicamento genérico que tem um valor mais acessível à população, nos casos dos medicamentos não ditos como essenciais, que não são distribuídos pela rede pública de saúde.

\subsubsection{Desequilíbrio nas relações de poder}

\subsubsection{Diferenças no poder de posição}

Pode-se afirmar que existe uma relação de poder entre o cuidador e aquele que recebe os cuidados. Nessa perspectiva, Carmo (2002, p. 6) ressalta que "tradicionalmente o que se nota na relação profissional e paciente é um domínio do conhecimento de um sobre a necessidade e o desconhecimento de outro". Diante do 
exposto, Barros e Fortes (2003) observam que a relação que se estabelece entre os vários profissionais (médico, enfermeiro e outros) e o paciente, invariavelmente, é imbuída de um poder dos primeiros sobre o segundo. O poder é reforçado por meio de um conhecimento técnico científico, restando ao paciente a posição passiva de recebimento de um bem que o outro lhe fez. Há então um desequilíbrio na relação de poderes a favor do profissional de saúde.

Sendo assim, o profissional de saúde, imbuído do poder de curar, tem status e prestígios especiais que, quando negados, podem desencadear abuso de poder, caracterizado por sentimentos de ameaça quando questionado e tomada de decisões unilaterais sobre o que considera melhor para o paciente sem uma discussão mais ampla sobre as condições do paciente e suas possibilidades (GAUDERER, 1998).

Explicita-se essa relação de poder nas falas:

"Não, não pode, não pode, não só eles" (E1).

Essa fala demonstra que o paciente acredita que não pode ter acesso à sua documentação médica. Ao dizer "não pode, só eles" evidencia a relação de poder de posição, ou seja, os profissionais podem ter esse acesso, mas somente eles.

"Humm... Sim, acho que acho que posso, não sei se vão deixar eu ter acesso mas que eu acredito que eu posso, sim" (E13).

O mesmo ocorre com a fala acima em que o participante acredita que pode ter esse acesso, entretanto "não sabe se vão deixar", desconhecendo seu direito de acesso a essas informações. Neste caso, observa-se uma relação de poder de posição ou cargo, que é legitimada pelo que o paciente tem preconcebido sobre o profissional.

Assim, o empoderamento da informação pelo paciente pode permitir que deixe a passividade, situação em que ele só recebe a informação, para se tornar sujeito, fazendo valer seus direitos que são garantidos por lei. 


\subsubsection{Diferenças no poder de especialização}

A questão da linguagem técnica ou de especialidade é explicitada por Lemaire e Imbert (1985) que argumentam que não há necessidade que os profissionais de saúde apresentem as informações em linguajar técnico científico. Elas precisam ser simples, aproximativas, inteligíveis, leais e respeitosas, ou seja, fornecidas dentro de padrões acessíveis à compreensão intelectual e cultural do paciente, pois quando indevidas e mal organizadas, resultam em baixo potencial informativo e em desinformação.

Nota-se menção a essa linguagem de especialidade na fala:

"Eu acho que é uma coisa muito... restrita, é os médicos com o paciente, eu sou a paciente mas aí eles vão me dar e eu não vou entender a linguagem né" (E6).

"O paciente deve ser corretamente informado sobre a sua doença, mediante uma linguagem adequada a seu entendimento, de modo que the permita ter um mínimo de controle estratégico sobre o curso da ação a ser seguida" (MONTE, 2002, p.34).

Entende-se, então, o direito à informação como o instrumento que pode tornar a pessoa, que tenha capacidade, apta para entender e decidir livremente sobre seu tratamento, sem coação interna ou externa, após ter recebido explicações a respeito dos riscos e benefícios, bem como das alternativas disponíveis (COELHO, 2000). Como a informação é um direito de todo cidadão, é também um meio de se tomar conhecimento e ter a autonomia sobre o que se está vivenciando.

Certamente, na medida em que os usuários forem ampliando o conhecimento sobre seus direitos e tendo mais condições para o exercício de sua cidadania, deixarão a condição de submissão e assumirão de modo mais efetivo seu papel de sujeitos autônomos, exigindo respeito e dignidade em relação a si e aos outros (SPIRI; BERTI; PEREIRA, 2006).

Assim, retoma-se o conceito de "padrão subjetivo" (COELHO et al. 2008; ENGELHARDT, 2004; FORTES, 1994, 2005) orientado a cada pessoa, devendo o profissional adequar a informação a cada paciente, de acordo com seu grau de instrução, conhecimento sobre a doença e sua saúde. 


\subsubsection{Sentimentos vivenciados ao receber informações}

Para melhor compreensão, esta categoria temática subdivide-se em 4 subcategorias.

\subsubsection{Satisfação ao receber as informações}

Dos 22 respondentes, 10 (45,5\%) (E:5;6;7;8;10;15;17;18;19;21) disseram que estão satisfeitos com as informações e atendimento recebidos.

Essas declarações corroboram os dados da pesquisa nacional de opinião a respeito do Sistema Único de Saúde (SUS), realizada em 2002 pelo Conselho Nacional de Secretários de Saúde (CONASS), em que são relatados dados que permitem compreender as percepções da população brasileira acerca do SUS. A avaliação geral do SUS expressa no percentual que considera que o sistema funciona bem ou muito bem é de 45,2\% nos usuários exclusivos do SUS, $41,6 \%$ nos usuários não exclusivos do SUS e 30,3\% nos não-usuários. Verifica-se, portanto, que a avaliação é mais positiva entre os que mais utilizam o sistema (BRASIL, 2006a).

Enfatiza-se, também, que os atendimentos realizados por médicos e enfermeiras são considerados importantes e são bem avaliados pela população.

A pesquisa do CONASS evidencia ainda que dentre os usuários dos serviços prestados pelo SUS, os graus de satisfação alta ou muito alta foram de: $79 \%$ nos serviços de vacinação; $60 \%$ nos serviços odontológicos; $56 \%$ nas consultas médicas; $62 \%$ nas consultas médicas especializadas; $63 \%$ nos exames laboratoriais; $67 \%$ nos exames de ultra-sonografia; $72 \%$ nas internações hospitalares; $80 \%$ nas cirurgias; e $81 \%$ nos serviços de alta complexidade. Os dados demonstram que, em geral, as avaliações do SUS, especialmente por aqueles que efetivamente utilizam o sistema, são favoráveis (BRASIL, 2006a).

Dessa forma, os dados deste estudo confirmam a pesquisa do CONASS, constatando essa satisfação nas falas: 
"A forma como te passam essas informações, a forma como você é tratada quando vai receber informações sobre a sua saúde, em relação a isso... eu acho que na minha opinião eles cumpre os papel deles, inclusive ontem eu vim aqui e o médico que me atendeu foi ótimo, sinceramente, é muito bom" (E7).

"E como a senhora se sente em relação ao tratamento que a senhora recebe dos profissionais durante a consulta, a senhora sai satisfeita... sai... com o que a senhora ouviu... é, eu tenho muita sorte... sai informada do que senhora tem... Eu sou bem intendida graças a Deus, tanto aqui como na UNAERP, sô muito bem tendida" (E17).

"É, até, até o momento eu... fico satisfeito porque, né? tem dado certo, alguma coisa que eu tenho sentido, tratado, então nada a reclamar" (E18).

"Satisfeita" (E19).

"Eu tô sendo bem atendida, normal" (E21).

Nesse contexto, dos 10 (45,5\%) respondentes que afirmam estar satisfeitos com as informações recebidas, 90\% (E: 6;7;8;10;15;17;18;21) são usuários efetivos do SUS, tendo utilizado o serviço mais de 6 vezes, e um (4,5\%) (E19) de 4 a 6 vezes. Apenas um usuário $(4,5 \%)$ (E5) utilizou o serviço de 1 a 3 vezes, evidenciando uma opinião satisfatória de usuários regulares do sistema.

\subsubsection{Insatisfação por não receber informações}

Dos 22 (100\%) entrevistados, houve 10 (45,5\%) usuários que tiveram sentimentos de insatisfação quando não receberam informações.

Essa insatisfação é relatada nas falas:

"Então como a senhora se sentiu diante... Eu me sinto lesada né, porque eu tô com dor, e eu quero saber o que vai fazer, se vão me pedir o raio x, se vão me da um atestado pra mim afastar, pra mim fazer um tratamento, porque eu tenho a consulta médica marcada mas é pro dia 23 de março, então eu não vou esperar dia 23 de março pra mim saber realmente o que é que eu tenho, né?, então enquanto isso eu vou tomando injeção, vô tomando medicação pra ver o que eu faço, e assim vai” (E1).

"Como que eu me sinto? É. Por exemplo, você falou que não recebe muitas informações, que você acha que deveria receber mais informações sobre 
seu estado de saúde, como você se sente em relação a isso? Ah me sinto prejudicado né, porque, tipo: a gente paga imposto pra eles te dá um atendimento bom e num, e eles não dá informação de nada. Quais informações você acha que deveria receber, e que você não recebeu? Ah, tipo assim, que nem: eles fizeram um exame, fala o que é que eu tenho, o diagnóstico, eles não explicam nada, só fala: "ó cê toma isso aqui que daqui dois dias cê tá melhor", é isso que eles falam [...] entendeu? Não explica muito" (E14).

"Em se tratando de saúde acho que ninguém se sente satisfeito com o resultado né, porque você tem que fazer o tratamento e tudo, e nenhum resultado é satisfatório a ninguém né, eu acredito né" (E7).

"Como eu recebo? É, como você se sente quando você recebe? Bom, então... a gente fica tão mal assim né, sem saber um pouco de nada né, sem entender um pouco também. Só a gente queria ter mais informação sobre a gente seria muito legal né" (E16).

"Ah, eu gostaria que explicasse melhor, sobre o que tá acontecendo, igual eu fiz um exame de intestino né, só que eu não sei o que tá acontecendo, porque eu tomo esse remédio, eu não.." (E22).

Os pacientes (E:3;4) (9\%) dizem que não sentem nada ou que depende do tipo de diagnóstico, se for um diagnóstico bom se sentem bem e se for um diagnóstico ruim se sentem mal.

"Não sinto nada, porque eu não tenho nada. Em relação aos profissionais eu me sinto respeitada, são ótimos profissionais" (E3).

"Vixi, aí depende do caso né, aí dependendo do caso você fica meio mal né, dependo do caso você fica meia normal né, dependendo do caso, é um caso normal, reage normalmente" (E4).

No entanto, dentre os usuários que se mostraram insatisfeitos $3(13,7 \%)$ utilizaram o sistema de 1 a 3 vezes; os outros 7 (31,8\%) já tinham sido consultados mais de 6 vezes. Ressalta-se que os pacientes que se mostram satisfeitos com as informações e atendimento recebidos na categoria anterior não são os mesmos que criticam a falta de informação e os outros problemas evidenciados nas categorias posteriores. Nesse sentido, há concordância entre as falas. 


\subsubsection{Falta de acesso a informações verdadeiras}

Vale mencionar ainda 0 direito do paciente de receber informações verdadeiras sobre seu estado de saúde. A verdade segundo Spiri, Berti e Pereira (2006) não significa simplesmente uma comunicação fria de dados e informações objetivas, pois é necessário tempo, oportunidade e condições adequadas para que ocorra essa transmissão.

Nesse sentido, os respondentes destacam :

"É, eu acho que o quadro clínico hoje dos pronto-socorro tá bem formado, a transparência deles com o paciente tá bem transparente, nóis tem a liberdade de passar tudo que pode acontecer, num esconde nada" (E5).

"Olha eu me sinto bem porque eu converso muito com meus médicos, eles não esconde nada, nada, nada, tudo que eu quero saber eles me informam, eu falo que é pra mim, que eu mesma quero saber que aí eu sei como é que eu me cuido, então eu sempre converso abertamente com meus médicos, nas clínicas, aqui também quando eu venho aqui eu converso, não tem [...] eu sou meio faladeira mesmo" (E10).

Outro participante adiciona, ainda, que gostaria de receber as informações verdadeiras sobre sua saúde. A informação verdadeira é imprescindível para que o paciente possa se manifestar de forma esclarecida acerca das ações que, segundo Fortes (1996), modificarão sua integridade física e psíquica.

\footnotetext{
"Que informações você sente falta de receber? Informações realmente verdadeiras, o que você tem, você entendeu? Olha você tem isso, você sofre disso, como é essa doença, explicar pra gente como é que é os procedimentos pra gente tá tomando, é, quais os medicamentos corretos pra tomar, como deveria ser tomado, entendeu, então tudo isso tá faltando um pouco também dentro das informações que os médicos dá pra gente. Eu já fui em médico já que disse: "ah eu não sei o que você tem, também não sei te informar", quer dizer, e aí? A gente fica na dúvida, a gente acaba desistindo e indo embora pra casa, sem saber o que realmente a gente tem né, e continua com aquela dor ou sei lá, continua doente sem saber o que a gente tem" (E11).
}

No extrato da fala acima mencionada fica clara a vulnerabilidade do paciente frente à sua falta de informação. A vulnerabilidade pode ser observada também na fala: 
"Primeiro de tudo, as duas vezes que eu vim consultar aqui eu entrei com dúvida e sai mais com dúvida ainda, porque, é..., eu entrei pensando que eu ia ter um, uma, um esclarecimento do quê que eu tinha, e eu saí sem resposta, sem êxito, sem nada, então resumindo, olha eu de volta aqui né. Hoje é dia 1 a e eu aqui tô aqui de volta" (E1).

Esclarece Kottow (2003, p.72) que "ser vulnerável significa estar suscetível a, ou em perigo de, sofrer danos". No seu sentido concreto, o vulnerável é aquele que pode ser atingido por algo no plano físico, psíquico, social ou moral. Isso remete à idéia de risco eminente que pode provocar sofrimento (VON ZUBEN, 2006).

Excluindo a vulnerabilidade intrínseca da existência humana que é até certo ponto protegida pela sociedade, as pessoas são afetadas por vulnerabilidades circunstanciais em decorrência da pobreza, da falta de acesso à educação, das doenças e da discriminação (KOTTOW, 2003). Acrescenta-se neste trabalho a falta de informação como condicionante da vulnerabilidade do sujeito.

São pessoas vulneráveis as absoluta ou relativamente incapazes de proteger seus próprios interesses. Especificamente, podem ter insuficientes poder, inteligência, educação, recursos, força ou outros atributos necessários para efetivar tal proteção (BARCHIFONTAINE, 2006).

Salienta-se, também, a precariedade de aspectos sociais ou econômicos. Nesta pesquisa o fato de a maioria dos entrevistados ter cursado apenas o ensino fundamental e ter renda de 1 a 3 salários mínimos revela esta precariedade e a maior vulnerabilidade dos sujeitos do estudo, bem como de grande parte da população brasileira, já que a renda média nacional $(R \$ 1.417,30)$ não alcança 3 salários mínimos (IBGE, 2010), informação que corrobora com a maioria dos sujeitos pesquisados, evidenciando não ser este um problema só deles, mas da população brasileira.

\subsubsection{Problemas na concretização do cuidado humanizado}

Os respondentes ressaltam a importância da concretização do cuidado humanizado no atendimento, o que pode ser evidenciado nas falas: 


\begin{abstract}
"Ah, quando a gente é bem diagnosticada, a gente sabe realmente o que a gente tem, a gente fica até tranqüilizada, agora eu tenho isso, agora eu vou tratar, entendeu? Aí quando a gente recebe uma informação desencontrada, não mas eu ainda tô sentindo esse sintoma e ele fala que eu não tenho nada, a gente fala assim, porque será que ele não procura investigar mais, tá entendendo? Mas, às vezes saber realmente o que você tem, aí também depende de médico, tem médico que dá, igual sabe você tem isso, explica direitinho o que a gente tem, aí a gente fica até com um certo alívio, e outro às vezes fala, olha você não tem nada, ou que você tem um probleminha só e pronto. Isso vai também de cada médico, vai da consciência de cada médico" (E11).
\end{abstract}

"Se tratassem a gente melhor... eu me sentiria mais confiante sobre os possíveis tratamentos né. [...] Quais as possibilidades poderia ser tomadas e tal, teria mais confiança no procedimento" (E20).

A confiança e tranqüilidade relatadas pelos respondentes são constituídas pelo vínculo terapêutico estabelecido entre profissional-paciente, em situações em que o profissional tem atitudes que propiciam segurança e confiança. O vínculo está presente desde os primeiros momentos de contato. O profissional deve dar atenção, ouvir, saber compreender os atos do paciente, orientá-lo sobre seu estado e o que deverá ser feito. Deve ainda identificar-se de maneira formal e o mesmo deve ser feito com familiares e/ou acompanhantes, estando receptivo ao paciente, abordando-o de forma respeitosa, mostrando-se sensibilizado com o seu sofrimento (FOWLER; SÁ, 2009).

Em outros casos, como na fala abaixo citada destaca-se um comportamento por vezes menos polido, com certa indiferença, sem a atenção e o respeito à que têm direito (CHAVES; COSTA; LUNARDI, 2005).

\begin{abstract}
"Bom, não me sinto bem amparada não, porque você pergunta e mal dá resposta, eles te fala com a maior frieza, com a maior né. E como a senhora se sente em relação a isso? Ah, me sinto muito mal porque acho que eles deviam ser mais humanos. Também trabalho na área da saúde, e acho que devia ser mais humanos e não tratar pacientes como se fosse um né, uma pessoa qualquer, se é um paciente devia tratar melhor" (E9).
\end{abstract}

Nesse sentido, como declara a usuária (E9), os profissionais deveriam ser mais humanos. Gauderer (1998) aponta ainda que a assistência prestada necessita ser humanizada, respeitosa e justa, favorecendo a comunicação e a interação entre a equipe e os pacientes, de modo que o respeito aos seus direitos como cidadãos sejam assegurados. Outrossim, há vários entraves que podem ser agregados ao ato de humanizar em saúde. Em muitos casos, deixa-se de perceber o imperceptível 
que inclui ver o paciente como um todo, um ser que tem emoções, medos, angústias e ansiedades que muitas vezes não são ditas, mas que é possível perceber através de pequenos gestos e olhares (FOWLER; SÁ, 2009).

Para ser prestada uma assistência, considerando a humanidade de quem é cuidado, é imprescindível ainda uma postura mais autônoma por parte dos pacientes, como forma de assegurar seus direitos. No entanto, para que as pessoas possam cuidar bem de si, torna-se necessário serem informadas para, assim, poderem lutar pelo que desejam e acreditam (CHAVES; COSTA; LUNARDI, 2005).

Assim, para que os direitos dos pacientes sejam efetivamente respeitados, 0 atendimento pela equipe de saúde necessita ser mais humanizado, uma vez que o paciente não é apenas uma doença, mas um ser com sentimentos que devem ser respeitados e considerados pelos profissionais de saúde.

\subsubsection{Paciente como número}

A legislação vigente introduz prerrogativas importantes, quais sejam, princípios estabelecidos na Carta dos Direitos dos Usuários da Saúde, 2006; Portaria no 1286 de 26 de outubro de 1993 e Lei Estadual 10.241/1999:

O paciente tem direito de ser identificado pelo nome e sobrenome, devendo existir em todo documento de identificação do usuário um campo para se registrar o nome pelo qual prefere ser chamado, independentemente do registro civil, não podendo ser tratado por número, nome da doença, códigos, de modo genérico, desrespeitoso ou preconceituoso (BRASIL, 1993; 2006b, SÃO PAULO, 1999).

Nesse contexto, Gomes et al. (2008) observam que os profissionais precisam perguntar para a pessoa o seu nome e como ela gosta de ser chamada. $O$ relacionamento deve obedecer, então, à referência que é dada pela própria pessoa.

Não obstante, como é amplamente admitido e propalado, um dos principais fatores que influenciam o aumento dos questionamentos dos serviços de saúde é a despersonalização da relação entre o profissional de saúde e o paciente, originada a partir da chamada "massificação" da medicina e dos serviços de saúde em geral (FERRAZ, 1997). 
O paciente sempre esteve em posição de subordinação e não raras vezes é visto como um "caso". A patologia que apresenta é discutida como se esta fosse o "sujeito", e o paciente um mero receptor do sujeito (BARROS; FORTES, 2003).

Diante disso, apresenta-se a fala do respondente:

\begin{abstract}
"Mas como você se sentiu em relação às informações que você recebeu? Você havia dito que quase não recebe informação... Não, eu não me senti, você se sente nada né? É o que a gente é aqui, um número, uma ficha, é assim. Eles não informam, não informam nada..." (E12).
\end{abstract}

Evidencia-se aqui, além do que foi relatado acima, o hábito relativamente disseminado de se referir a pacientes pelo diagnóstico (a "hepatite" da enfermaria $\mathrm{x}$ ) ou pelo procedimento realizado (o "cateterismo" do leito y), o que contribui ainda mais para a despersonalização já induzida pelo próprio ambiente institucional em geral (SOAR FILHO, 1998). Essa despersonalização pode ser entendida como uma situação de desrespeito aos direitos dos pacientes, à medida que são tratados como coisas, como objetos, como números, dependendo do cuidado dos profissionais da saúde.

Lamentavelmente, em muitos momentos, os profissionais de saúde, durante a prestação de assistência aos usuários chegam a esquecer que essas pessoas têm uma identidade e que vivenciam seus problemas como pessoas inseridas em uma determinada realidade e necessitam ter seus direitos preservados. Esses profissionais ficam tão envolvidos com a doença, os recursos tecnológicos e as sofisticações técnicas que em muitas situações não priorizam o aspecto humano (VELOSO; SPINDOLA, 2005).

O depoimento da usuária (E9) esclarece que :

"Bom, não me sinto bem amparada não, porque você pergunta e mal dá resposta, eles te fala com a maior frieza, com a maior né" (E9).

O usuário do serviço de saúde quer ser tratado como um conjunto biopsicossocial. Porém, percebe que, ao chegar para ser atendido, deixa de ser uma pessoa, recebendo um tratamento da equipe de saúde que desconsidera sua identidade, sua história de vida, tornando-se, então, apenas um leito ou uma doença que precisa ser tratada (VELOSO; SPINDOLA, 2005). 


\title{
4.2.7.1 Dificuldades na relação interpessoal com o paciente devido à rapidez dos atendimentos
}

Outro ponto a ressaltar é a rapidez nas consultas médicas, favorecendo um ambiente frio e desumano. Pacientes reclamam que os médicos não os examinam, apenas prescrevendo medicamentos sem uma prévia avaliação:

\begin{abstract}
"Tanto que nem por a mão em mim ela não colocou né, ela só falou ela lá e eu aqui... Porque, primeiro de tudo, se eu chegar lá e falar que eu tô com dor de barriga ela dá o remédio pra dor de barriga, ela vai me consultar pelo que eu tô falando entendeu? Ela não me examina pra saber o que eu tenho, não pede exame, entendeu?" (E1).
\end{abstract}

Nesse contexto, o usuário tem o direito a receber a melhor qualidade possível de atendimento, "fundado numa sólida base de conhecimentos e proporcionado por pessoas que podem empregar essas bases de conhecimento aplicando juízos e raciocínios acertados e um sistema de valores claro e conveniente" (SPIRI; BERTI; PEREIRA, 2006, p. 451-452).

Assim, o cansaço, a vontade de concluir a consulta e a pressão criada por outros pacientes na sala de espera podem levar o médico a apenas entregar uma receita, sem dar atenção ao paciente/acompanhante (ZANINI, 1997), conforme explicita a fala:

\begin{abstract}
"Hummmm... às vezes me sinto revoltado, quando você chega você tá com determinada dor, sentindo alguma coisa, fazem os exames, às vezes o médico nem ouve muito bem o que você tá dizendo, você tá dizendo que tá sentindo e ele já tá terminando de fazer a prescrição mesmo antes, às vezes nem te faz uma avaliação, às vezes nem toca em você, ele olha pra você como se fosse um, um médium ali, olhando pra você e escreve e assim não tem, não dá muito espaço pra você dizer o que realmente está sentindo e nem presta interesse que a gente percebe, que ele tem interesse que você entre no consultório ele faça a prescrição e você vá embora logo, acho que o interesse não é em descobrir o que o paciente tem, mas sim liberar o espaço pra vir o próximo e assim sucessivamente" (E13).
\end{abstract}

Veloso e Spindola (2005) esclarecem que aqueles que se propõem a assistir o ser humano necessitam assumir uma postura de respeito e compromisso, valorizando a experiência de vida dos usuários do serviço em que trabalham, possibilitando-Ihes preservar sua individualidade, pois cada pessoa necessita de um 
cuidado. Logo, é perigoso voltar-se apenas para a doença, pois uma mesma enfermidade poderá apresentar manifestações diferentes em pessoas distintas.

\subsubsection{Dificuldade de exercer o direito de escolha do profissional da saúde}

Destaca-se também a dificuldade que o paciente tem de exercer o direito de escolha do profissional que irá atendê-lo, pois o que ocorre nas Unidades Básicas de Saúde, na maioria das vezes, é que o usuário marca consulta com o médico que está disponível, não tendo o respeito a esse direito. Como segue:

\footnotetext{
"Então eu acho que a gente tem que ir com o médico que a gente se sente, se sinta bem né?"(E21).

\begin{abstract}
"Graças à Deus eu quase não tenho nada grave né, só problema de colesterol essas coisa. Teve uma vez só, mas já faz tempo. O quê? Eu tava, eu troquei de médico, eu não gostei do médico que eu tava indo, aí eu troquei, aí a que eu fui me chamou atenção. Eu marquei consulta com ela, não deveria ter marcado consulta com ela, ela não queria me atender, ela queria que eu voltasse pro outro médico. Mas aí eu não voltei, fiquei, fiquei um bom tempo sem voltar, aí ela me receitou, eu fiquei um tempão sem ir aí minha amiga foi, minha amiga marca sempre com ela e pra ela ela não falou nada não. Eu acho que a gente tem direito de escolha, se eu não tava sei lá, eu não gostei do jeito do médico, não me senti bem aí me falaram que ela era muito boa, aí eu marquei com ela ai ela me fala daquele jeito" (E2).
\end{abstract}

Nessa perspectiva, Lopes (2000) destaca que a dignidade da pessoa está ligada à sua capacidade de agir humanamente, e agir de maneira humana é agir livremente escolhendo seus planos e seus fins.

Diante disto, a liberdade é também algo conquistado pela pessoa. O usuário, ao tomar conhecimento de seus direitos e deveres, assume, também, a responsabilidade pelo seu tratamento e colabora (ou não) para o seu êxito (VELOSO; SPINDOLA, 2005).

Nesse sentido, sendo respeitado o direito de escolha do paciente, preserva-se também sua dignidade e liberdade. 


\subsubsection{Excesso de burocracia no atendimento}

Esta categoria evidencia a burocracia no atendimento do SUS, bem como a indignação por parte do usuário com relação à demora e à forma como é organizado o sistema, pois ao utilizar o serviço de emergência um usuário não é encaminhado diretamente para o especialista. O paciente vai até a Unidade Básica de Saúde, com uma emergência, é encaminhado para o Clínico Geral e só então é encaminhado para o especialista.

\begin{abstract}
"Como que eu me sinto? Eu me sinto consciente da minha situação, o que eu tenho que seguir, o que eu tenho que fazer não é? naquele momento que eu venho e que o médico, como eu estou aqui hoje né, problema de um rim operado no $\mathrm{HC}$ e se eu não passar por aqui eu não chego no HC não é bem? E... e então eu acho que está tudo muito bem feito, tem o seguimento direitinho rotina deles né, só que às vezes a gente acha que tá demorando né, cê entendeu? Pelo que a gente tá sentindo, a dor, a gente, eu pelo menos acho assim, como o profissional tá me atendendo à noite e no dia seguinte eu preciso de um clínico geral pra me encaminhar, pra fazer o encaminhamento pra uma ultrassom, pra qualquer coisa, que aquele médico que me atendeu a noite ele já poderia, cê entendeu? Adiantar, quando vê que a gente está mesmo com a dor, né bem? Entendeu bem? A idade, tudo isso, é isso só que eu acho que devia ser assim, mas a gente não sabe o, como é que fala? O desencadear, o ritmo, a organização deles né bem, o tanto de gente [...]. Só isso bem, já falei muito" (E6).
\end{abstract}

"... até porque eu queria um novo exame aqui e aqui não é urologista né, é um outro nome ... Mas será que não é a especialidade dele? Não é, é outra especialidade, só que ele tem que dar o encaminhamento" (E22).

"...Uma vez eu vim pedi um exame, eu vim consulta e ele me deu uma guia com uns exames lá na UNAERP, de tiróide, mas como eu trato lá na UNAERP eles não quis fazer, o exame, não fizeram. Eles fazem o meu exame de tiróide, num fala se tá bom, se tá ruim ou se eu preciso tomar remédio ou não" (E17).

As falas acima demonstram a hierarquização e a regionalização do SUS (BRASIL, 2006d, 2007). No que diz respeito à organização segundo níveis de complexidade, quais sejam, baixa, média e alta, o usuário do serviço critica o excesso de burocracia e a demora no atendimento. 
O direito humano à saúde se concretiza com a constitucionalização desse direito como social no ordenamento jurídico nacional. A partir da CRFB/1988, a saúde passa a ser tratada como direito do cidadão e sua garantia é estabelecida como dever do Estado. A institucionalização do SUS em 1990, apregoando caráter de atendimento universal, equânime e integral, vem de encontro à constitucionalização desse direito. Nesta pesquisa, portanto, pôde-se observar facilidades e dificuldades enfrentadas pelos usuários do sistema em relação ao acesso à informação em saúde.

O direito fundamental à informação em saúde é um direito que se legitima a partir da informação mediada pelo profissional de saúde permitindo com que o paciente se empodere desta informação, gerando conhecimento e, conseqüentemente, possibilitando que exerça sua cidadania.

Em relação ao direito à informação, a Lei 10.241/1999 estabelece que o paciente tem direito de receber informações claras, objetivas e compreensíveis sobre: a) hipóteses diagnósticas; b) diagnósticos realizados; c) exames solicitados; d) ações terapêuticas; e) riscos, benefícios e inconvenientes das medidas diagnósticas e terapêuticas propostas; f) duração prevista do tratamento proposto; g) no caso de procedimentos de diagnósticos e terapêuticos invasivos, a necessidade ou não de anestesia, o tipo de anestesia a ser aplicada, o instrumental a ser utilizado, as partes do corpo afetadas, os efeitos colaterais, os riscos e conseqüências indesejáveis e a duração esperada do procedimento; h) exames e condutas a que será submetido; i) a finalidade dos materiais coletados para exame; j) alternativas de diagnósticos e terapêuticas existentes, no serviço de atendimento ou em outros serviços; e I) o que julgar necessário (BRASIL, 1999).

Com base nesta lei e considerando o acesso a informações sobre diagnóstico, exames, medicamento e riscos e benefícios do tratamento, os resultados do estudo demonstram que os pacientes receberam informações sobre diagnóstico $(45,5 \%)$, exames $(63,7 \%)$, medicamentos $(36,4 \%)$ e riscos e benefícios do tratamento $(45,5 \%)$. Todavia, há ainda grande número de pacientes que não receberam esse tipo de informação: pacientes que não receberam informações sobre diagnóstico (36,4\%); sobre exames $(27,3 \%)$, sobre medicamentos $(36,4 \%)$ e sobre riscos e benefícios do tratamento $(31,8 \%)$. 
Pode-se afirmar que os pacientes têm acesso a informações sobre 0 diagnóstico, exames e riscos e benefícios do tratamento em número superior ao de usuários que não recebem essas informações. Em contrapartida, alerta-se para o acesso a informações sobre medicamentos, já que este ocorreu em igual porcentagem tanto dos que receberam informações, quanto dos usuários que relataram não as terem recebido. Nesse sentido, 36,8\% dos usuários terem recebido informações sobre medicamentos, pode ser considerado um número baixo, em relação à importância desta informação.

Apesar de não ser o cenário ideal e o estudo ter apontado lacunas na comunicação entre os profissionais de saúde e os usuários do serviço, ressalta-se que as necessidades informacionais dos usuários quanto à diagnóstico, exames, medicamentos, riscos e benefícios do tratamento estão sendo supridas parcialmente, o que denota o início do estabelecimento de relações mais democráticas entre profissional de saúde e paciente.

A Lei 10.241/1999 afirma ainda que o paciente tem o direito de consentir ou recusar, de forma livre, voluntária e esclarecida, com adequada informação, sobre procedimentos diagnósticos ou terapêuticos a serem nele realizados.

Destaca-se, a partir do inciso citado, outra deficiência nesta comunicação que ocorre em relação ao consentimento esclarecido do usuário, já que apenas $22,7 \%$ dos entrevistados foram consultados se consentiam com os procedimentos e tratamentos propostos. Destes ainda, nenhum teve acesso físico ao documento por escrito, tendo sido utilizado apenas o consentimento verbal. Os restantes não foram consultados e nem tiveram informação sobre o termo de consentimento esclarecido.

Pela mesma lei estadual, o paciente tem o direito de acessar, a qualquer momento, o seu prontuário médico. Sendo assim, enfatiza-se que este direito não se concretizou nesta pesquisa, já que todos os respondentes nunca tiveram acesso ao seu prontuário. O conhecimento sobre o possível acesso ao prontuário foi efetivado apenas por dois usuários, enquanto $91 \%$ desconheciam essa possibilidade e também seu direito caso de necessidade.

Nota-se neste ponto, que a falta de informação do usuário do que lhe é garantida por lei, faz com que este não tenha condições de reivindicar seus direitos. 
Ainda a lei 10.241/1999 ressalta que é direito do paciente receber as receitas: com o nome genérico das substâncias prescritas; datilografadas ou em caligrafia legível; sem a utilização de códigos ou abreviaturas; com o nome do profissional e seu número de registro no órgão de controle e regulamentação da profissão; e com assinatura do profissional.

Sobre esse acesso, mais da metade dos entrevistados (63,7\%) relataram não ter acesso às receitas totalmente legíveis, enquanto apenas 27,3\% disseram entender as prescrições, ressaltando o baixo acesso cognitivo à essa informação. Nesse contexto, houve críticas às letras dos médicos. Sobre as especificidades em relação às prescrições, grande número de usuários, $81,8 \%$ dos entrevistados receberam as prescrições com o nome genérico do medicamento, entretanto $9 \%$ dos respondentes enfatizam que não sabem diferenciar o medicamento genérico do medicamento de referência.

Entraves ao acesso a informações foram relatados pelos usuários do serviço:

- As diferenças de poder de especialização entre o usuário e o profissional de saúde representam um problema mencionado pelos usuários do serviço. Houve queixas de que o paciente não entendia a linguagem utilizada. Muitas vezes os profissionais de saúde conversam entre si e com os pacientes em linguagem técnica não compreensível ao leigo. Assim, enfatiza-se a necessidade de adoção do padrão subjetivo, em que o profissional direciona e adapta a forma de se comunicar de acordo com cada usuário, considerando seus conhecimentos e sua vivência.

- Sobre o poder de posição ou cargo, constata-se que o paciente acredita que pode ter acesso à informação, como por exemplo, à sua documentação médica. Outrossim, em contrapartida, os usuários argumentam que os profissionais não vão deixá-lo ter esse acesso ou, ainda, que somente os profissionais têm esse acesso, explicitando uma forma de poder que se legitima com a noção que o paciente tem de que há uma grande diferença de posição, como uma hierarquia, entre o profissional e ele. Nesse sentido, observa-se que os profissionais de saúde ainda têm dificuldades de realmente exercer a mediação de 
forma efetiva em sua relação com os pacientes, compreendendo-os como seres humanos, com suas especificidades e necessidades distintas e buscando minimizar os efeitos desta diferença de poder de posição.

- A falta de acesso a informações verdadeiras sobre sua saúde também é apontada como uma dificuldade pelos usuários, já que gostariam de receber informações verdadeiras e com melhor qualidade. Os entrevistados enfatizaram que a verdade, o respeito e a empatia com relação ao outro podem fortalecer e humanizar a relação profissional de saúde-usuário.

- As dificuldades na relação interpessoal com o paciente são citadas, especialmente em virtude da rapidez nos atendimentos, já que o profissional, ao atender muitos usuários em pouco tempo, não Ihes dá o atendimento com a qualidade esperada, muitas vezes, tratando-os como um número, uma ficha, uma doença. Em alguns casos, salientase ainda que o profissional prescreve medicamentos a partir apenas do que diz o paciente, não o examinando e tampouco ouvindo às suas queixas, ressaltando-se, aqui, a despersonalização do paciente.

- Ainda sobre as dificuldades encontradas, enfatiza-se o direito de escolha do paciente quanto ao profissional que irá atendê-lo, já que, muitas vezes, no SUS, o que ocorrem são consultas agendadas sem o paciente ter condições de exercer o seu direito de livre escolha deste profissional.

- Os resultados também demonstram dificuldades enfrentadas pelos pacientes para ter acesso físico à informação, como, por exemplo, ao seu prontuário médico, ao termo de consentimento livre e esclarecido por escrito e à receitas totalmente legíveis.

- Ressalta-se também grande número (45,5\%) de pacientes que se sentem insatisfeitos com o atendimento e com as informações que não são recebidas, de acordo com os entraves já mencionados.

- Completando as dificuldades relatadas, o excesso de burocracia no sistema é um problema evidenciado já que atrapalha o funcionamento 
e a integralidade apregoada pelo SUS. Nessa perspectiva, observa-se que o problema não é a existência de formalização, necessária em organizações tão grandes como o SUS, mas sim o excesso de regras, que ao invés de facilitarem o processo de trabalho, muitas vezes dificultam a eficiência e eficácia do serviço prestado ao usuário do sistema de saúde.

Em contrapartida, facilidades no acesso à informação foram também relatadas:

- A maioria dos entrevistados reconhece os medicamentos genéricos e apontam que os recebem na própria UBDS. Assim, pode-se afirmar que a Política de Medicamentos do Ministério da Saúde está sendo posta em prática e que a informação, o acesso físico ao medicamento genérico e o acesso cognitivo a essa informação se concretizam. Todavia, acredita-se que as informações sobre medicamentos podem ser ainda mais efetivas, uma vez que houve relatos de pacientes que não sabiam diferenciar medicamento genérico do medicamento de referência.

- Uma grande parte dos respondentes (45,5\%), disseram estar satisfeitos em relação a informações recebidas sobre sua saúde, ressaltando que $90 \%$ destes pacientes são usuários efetivos do SUS.

- Apesar das lacunas no processo de comunicação, as necessidades informacionais relacionadas ao diagnóstico, exames, medicamentos ou riscos e benefícios do tratamento foram parcialmente atendidas.

Em suma, pode-se afirmar que o exercício do direito à informação em saúde é pré-condição para a diminuição da vulnerabilidade e empoderamento do paciente, permitindo que exerça as diferentes possibilidades de escolha relacionadas à sua própria saúde e, assim, tenha condições de se tornar um dos sujeitos da relação profissional de saúde e usuário. Ressalta-se, portanto, que somente a combinação do acesso físico e do acesso cognitivo à informação permite a geração de conhecimento em saúde e o efetivo exercício da cidadania em saúde.

Outrossim, para que realmente exista um equilíbrio entre os poderes dos envolvidos neste processo, é fundamental que os profissionais de saúde 
reconheçam o paciente como usuário, ou melhor, como um ser humano, que possui uma história de vida distinta, sentimentos e necessidades e não apenas como "mais um" paciente a ser atendido dentre muitos números e doenças. Para que isto aconteça e se estabeleça um cuidado realmente integral e humanizado, o profissional deve se utilizar de um padrão subjetivo em sua comunicação com o usuário, atuando como um verdadeiro mediador nesta relação. Nessa perspectiva, o profissional de saúde busca se colocar no lugar do outro compreendendo as suas particularidades.

Contudo, apesar dos princípios que regem o modelo do SUS preconizarem a integralidade e a humanização do cuidado, na prática o sistema representa um modelo em construção, que enfrenta desafios na gestão operacional e de recursos humanos. A sobrecarga de atendimentos, a escassez de apoio humano e de recursos físicos, bem como o excesso de formalização constituem, nesse contexto, sérios obstáculos para a transformação do paciente em usuário em sua relação com o profissional de saúde e por meio do exercício do seu direito à informação em saúde.

Apesar das lacunas e desafios existentes, o estudo apontou indícios e possibilidades de mudança para a construção conjunta de relações mais democráticas, em que o usuário, como sujeito, exerce direitos, mas também tem consciência de suas obrigações como cidadão, especialmente no que diz respeito à sua relação com o profissional e o serviço de saúde.

Destaca-se como limitação da pesquisa, a impossibilidade de generalização dos dados, já que o estudo foi realizado em apenas uma UBDS da cidade de Ribeirão Preto. Nesse sentido, sugere-se o desenvolvimento de investigações que abordem o exercício do direito à informação em saúde em outros serviços de saúde e em outras regiões do país. Propõe-se, também, como sugestão ao final desta pesquisa, que se estabeleçam políticas públicas de educação e esclarecimento da população sobre o seu direito à informação, bem como na formação de mediadores desta informação, com o intuito de possibilitar o acesso tanto físico como cognitivo das pessoas à informação sobre os seus direitos como usuários do serviço público de saúde. Os acessos físico e cognitivo são pré-condições para o empoderamento do paciente, oferecendo-Ihe a possibilidade de se tornar um real usuário, consciente de seus direitos e deveres relacionados à sua saúde. 
REFERÊNCIAS 
ALMEIDA JÚNIOR, O. F. Mediação da informação e múltiplas linguagens. Pesquisa Brasileira em Ciência da Informação, Brasília, v. 2, n. 1, p. 89-103, 2009.

Mediação da informação: ampliando o conceito de disseminação. In: VALENTIN, M. (Org). Gestão da informação e do conhecimento no âmbito da ciência da informação. São Paulo: Polis, 2008. p. 41-54.

ANDRADE, E. N.; ANDRADE, E. O. O SUS e o direito à saúde do brasileiro: leitura de seus princípios, com ênfase na universalidade da cobertura. Revista Bioética, Brasília, v. 18, n. 1, p. 61-74, 2010.

BARCHIFONTAINE, C. P. Vulnerabilidade e dignidade humana. O Mundo da Saúde, São Paulo, v. 30, n. 3, p. 434-440, jul./set. 2006.

BACKES, D. S. et al. O que os usuários pensam e falam do Sistema Único de Saúde? uma análise dos significados à luz da carta dos direitos dos usuários. Ciência e Saúde Coletiva, Rio de Janeiro, v. 14. n. 3, p. 903-910, 2009.

BARDIN, L. Análise de conteúdo. Lisboa: Edições 70, 1977.

BARROS, V. L. O informar e o consentir enquanto atributos fundamentais para a consolidação dos direitos do paciente. 2000. 108 f. Dissertação (Mestrado em Saúde Pública) - Faculdade de Saúde Pública, Universidade de São Paulo, São Paulo, 2000.

BARROS, V. L.; FORTES, P. A. C. A Informação esclarecedora e o consentimento esclarecido: um desafio ao Programa de Saúde da Família na garantia dos direitos do paciente. O Mundo da Saúde, São Paulo, v. 27, n. 2, p. 281-291, 2003.

BECHARA, S. J. Aspectos médico-legais do trauma ocular. In: TAKAHASHI, W. Traumatismos e urgências oculares. São Paulo: Roca, v. 5, p. 241-246, 2003. (Série Oftalmologia - USP).

BIONDO-SIMÕES, M. L. P. et al. Compreensão do termo de consentimento informado. Revista do Colégio Brasileiro de Cirurgiões, Rio de Janeiro, v. 34, n. 3, p. 183-188, 2007.

BITTAR, O.J.N.U. Aspectos legais do prontuário médico no Brasil. Revista Paulista de Hospitais, v. 28, n. 8, p. 239-243, ago. 1980. 793p. 
BOBBIO, N. A era dos direitos. Rio de Janeiro: Câmpus, 1992. 217p.

BONAVIDES, P. Curso de direito constitucional. 10. ed. São Paulo: Malheiros, 2000. $793 \mathrm{p}$.

BRASIL. Centro Nacional de Epidemiologia. Parecer oㅜ 196/96 de 10 de outubro de 1996. Pesquisa envolvendo seres humanos. In: Informe Epidemiológico do SUS Supl. 3, p. 278-291. Brasília: Fundação Nacional de Saúde, 1996.

. Conselho Nacional de Secretários de Saúde. SUS: avanços e desafios. Brasília: CONASS, 2006a. 164 p.

Constituição (1988). Constituição da República Federativa do Brasil. Brasília, DF: Senado, 1988.

. Decreto Presidencial o 94657, de 13 de julho de 1987. Dispõe sobre a criação de Sistemas Unificados e Descentralizados de Saúde nos Estados (SUDS) e dá outras providências. Diário Oficial da União, Brasília, DF, 21 jul. 1987.

. Ministério da Saúde. Caminhos do direito à saúde no Brasil. Brasília: Editora do Ministério da Saúde, 2007. 24p.

. Ministério da Saúde. Carta dos direitos dos usuários da saúde. Brasília: Ministério da Saúde, 2006b. 8 p.

. Ministério da Saúde. Gestão financeira do SUS: manual básico. 3. ed. Brasília: Ministério da Saúde, 2003. 65 p.

Ministério da Saúde. Portaria no 1286 de 26 de outubro de 1993. Dispõe sobre os direitos do paciente. Diário oficial da União, Brasília, DF, 4 mai. 1994.

. Ministério da Saúde. Portaria no . 3.916. Dispõe sobre a aprovação da Política Nacional de Medicamentos. Diário Oficial da União, Brasília, DF, 30 out. 1998.

. Ministério da Saúde. Relação nacional de medicamentos essenciais RENAME. Brasília: Ministério da Saúde, 2006c. 
- Ministério da Saúde. Secretaria de Gestão Estratégica e Participativa. A construção do SUS: histórias da reforma sanitária e do processo participativo Brasília: Ministério da Saúde, 2006d.192 p.

. Lei 8.080 de 19 de setembro de 1990. Dispõe sobre as condições para a promoção, proteção e recuperação da saúde, a organização e o funcionamento dos serviços correspondentes e dá outras providências. Diário Oficial da União, Brasília, DF, 20 set. 1990. Disponível em: < http://www.planalto.gov.br/ccivil_03/Leis/L8080.htm>. Acesso em: 15 jun. 2007.

. Lei no 9.787, de 10 de fevereiro de 1999. Altera a Lei no 6.360, de 23 de setembro de 1976, que dispõe sobre a vigilância sanitária, estabelece o medicamento genérico, dispõe sobre a utilização de nomes genéricos em produtos farmacêuticos e dá outras providências. Diário Oficial da União, Brasília, DF, 11 fev. 1999. Disponível em: <http://www.planalto.gov.br/ccivil_03/Leis/L9787.htm>. Acesso em: 20 mar. 2010.

BUCKLAND, M. K. Information as thing. Journal of the American Society for Information Science, New York, v. 42, n. 5, p. 351-360, 1991.

CANOTILHO, J. J. G. Direito constitucional e teoria da constituição. 7. ed. Coimbra: Almedina, 2003. 1522 p.

CARMO, D. R. B. Possibilidade de manifestação da autonomia do paciente internado em um hospital universitário. 2002. 94 f. Dissertação (Mestrado em Enfermagem) - Escola de Enfermagem de Ribeirão Preto, Universidade de São Paulo, Ribeirão Preto, 2002.

CARVALHO, S. R. Os múltiplos sentidos da categoria "empowerment" no projeto de promoção à saúde. Cadernos de Saúde Pública, Rio de Janeiro, v. 20, n. 4, p. 1088-1095, jul-ago. 2004.

CARVALHO, R. S. et al. Prontuário incompleto no pronto-socorro: uma barreira para a qualidade em saúde. Cyber Saúde, 2008. Disponível em: <http://www.cibersaude.com.br/revistas.asp?fase=r003\&id_materia=4057>. Acesso em: 10 jan. 2010.

CHAVES, P. L.; COSTA, V. T. C.; LUNARDI, V. L. A enfermagem frente aos direitos de pacientes hospitalizados. Texto Contexto Enfermagem, Florianópolis, v. 14, n. 1, p. 38-43, 2005. 
CITI - Centro de Investigação para Tecnologias Interactivas da Universidade Nova de Lisboa, 2006. Disponível em: <http://www.citi.pt/educacao_final/trab_final inteligencia_artificial/cognicao.html>. Acesso em: 13 fev. 2010.

CLOTET, J. O consentimento informado nos comitês de ética em pesquisa e na pratica médica: conceituação, origens e atualidade. Bioética, Brasília, v. 3, p. 51-59, 1995.

COELHO, L. C. D. Fundamentação dos juízos morais na enfermagem. 2000. 298 f. Tese (Doutorado em Enfermagem Fundamental) - Escola de Enfermagem de Ribeirão Preto, Universidade de São Paulo, Ribeirão Preto, 2000.

COELHO, L. C. D. et al. Conflitos éticos na revelação de informações - Parte II. Ciência Cuidado e Saúde, Maringá, v. 7, n. 1, p. 73-82, 2008.

COHEN, C.; MARCOLINO, J. A. M. Relação médico paciente. In: SEGRE, M.; COHEN, C.(org.). Bioética. 3. ed. rev. ampl. São Paulo: EDUSP, 2002. p. 83-119.

CONSELHO FEDERAL DE MEDICINA. Resolução № 1.638 de 10 de julho de 2002. Define prontuário médico e torna obrigatória a criação da Comissão de Revisão de prontuários nas instituições de saúde. Brasília. Diário Oficial da União, № 153, seção 1.

CONSELHO FEDERAL DE MEDICINA. Código de ética médica: Resolução CFM no 1931, de 17 de setembro de 2009. Brasília: Conselho Federal de Medicina, 2010. 98p. Disponível em: <http://www.crmdf.org.br/files/outros/novo.pdf>. Acesso em: 20 Abr. 2010.

CULVER, C.M. Competência do paciente. In: SEGRE, M.; COHEN, C.(Org.). Bioética. 3. ed. rev. ampl. São Paulo: EDUSP, 2002. p. 95-105.

CURY, I. T. Direito fundamental à saúde: evolução, normatização e efetividade. Rio de Janeiro: Lúmen, 2005. 165p.

DALLARI, D. A. O que são direitos da pessoa. 5. ed. São Paulo: Brasiliense, 1985. $83 \mathrm{p}$.

DALLARI, S. G. Os estados brasileiros e o direito à saúde. São Paulo: Hucitec, 1995. $133 \mathrm{p}$. 
DAMASCENO, M. C. T. Aspectos ético-legais no pronto-socorro. In: MARTINS, H. S.; DAMASCENO, M. C. T.; AWADA, S. B. Pronto socorro: condutas do Hospital das Clínicas da Faculdade de Medicina da Universidade de São Paulo. São Paulo: Manole, 2006. p. 16-22.

DA ROS, M. A. Uma visão da reforma curricular a partir do movimento sanitário. In: PEREIRA, M. J. L.; COELHO, E. B. S.; DA ROS, M. A. (Org.). Da proposta à ação: currículo integrado do Curso de Medicina da UFSC. Florianópolis: Ed. UFSC, 2005. p. $59-80$.

DAVALLON, J. La médiation: la communication en procès? Médiations \& Médiateurs, Paris, n.19, p. 37-59, 2004.

DEMANTHÉ, T.; CUNHA, L. Compreensão, pelos acompanhantes, do conteúdo da receita médica nos atendimentos pediátricos em postos de saúde pública em Tubarão, SC. Arquivos Catarinenses de Medicina. Florianópolis, v. 37, n. 2, p. 5158, 2008.

DESLANDES, S. F. Pesquisa social: teoria, método e criatividade. Petrópolis, Rio de Janeiro: Vozes, 1994. 80 p.

ENGELHARDT, T. H. Fundamentos de bioética. trad. J. A. Ceschin, São Paulo: Loyola, 2004. $518 \mathrm{p}$.

ESCOREL, S. Reviravolta na saúde: origem e articulação do movimento sanitário. Rio de Janeiro: Fiocruz, 1998. 206p.

FERRAZ, O. L. M. Questionamentos judiciais e a proteção contra o paciente: um sofisma a ser corrigido pelo gerenciamento de riscos. Bioética, v. 5, n. 1, 1997. Disponível em: <http://www.portalmedico.org.br/revista/bio1v5/questiona.html>. Acesso em: 20 mai. 2009.

FINKELMAN, J. (Org.). Caminhos da saúde pública no Brasil. Rio de Janeiro: Fiocruz, 2002. $326 \mathrm{p}$.

FORTES, P. A. C. Reflexões sobre a bioética e o consentimento esclarecido. Bioética, Brasília, v. 2, n. 2, p. 129-135, 1994.

. Ética, cidadania e busca da qualidade na administração dos serviços de saúde. Saúde em Debate, São Paulo, n. 49/50, p. 48-52, 1996. 
Ética e saúde: questões éticas, deontológicas e legais. Tomada de decisões, autonomia e direitos do paciente. Estudo de casos. São Paulo: EPU, 2005. $119 \mathrm{p}$.

FOWLER, D. J.; SÁ, A. C. Humanização nos cuidados de pacientes com doenças crônico-degenerativas. O Mundo da Saúde, São Paulo, v. 33, n. 2, p. 225-230, 2009.

FREIRE, P. Pedagogia da autonomia: saberes necessários à prática educativa. São Paulo: Paz e Terra, 2003. 148p.

GAUDERER, E. C. Os direitos do paciente: um manual de sobrevivência. 6. ed. Rio de Janeiro: Record, 1998. 223 p.

GELLEREAU, M. Pratiques culturelles et médiation. In: OLIVESI, S. Sciences de I'information et de la communication: objets, savoirs, discipline. Grenoble: Presses Universitaires de Grenoble, 2006, p. 43-62.

GIL, A. C. Métodos e técnicas de pesquisa social. 5. ed. São Paulo: Atlas, 1999. 206p.

GLASER, B.; STRAUSS, A. The discovery of grounded theory: strategies for qualitative research. New Brunswick: Aldine Transaction, 2008. 271 p.

GOMES, A. M. A. et al. Código dos direitos e deveres da pessoa hospitalizada no SUS: o cotidiano hospitalar na roda de conversa. Interface, Botucatu, v. 12, n. 27, p. 773-782, 2008.

GOMES, I. L. V.; FRAGA, M. N. O. Direitos do cidadão hospitalizado: teoria e práxis. Fortaleza: Ban Gráfica, 2001.

GOMES, H. F. A mediação da informação, comunicação e educação na construção do conhecimento. Datagrama zero, v.9, n.1, fev. 2008. Disponível em: <http://www.dgz.org.br/fev08/Art_01.htm> Acesso em: 01 jan 2010.

HIGGINBOTHAM, N.; STREINER, D. L. The social science contribution to pharmacoepidemiology. Journal of Clinical Epidemiology, Oxford, v. 44, suppl. 2, p. 73s-82s, 1991. 
HOBBES, T. Leviatã. São Paulo: Abril Cultural, 1993.

HOLM, S. What is wrong with compliance? Journal of Medical Ethics, London, v. 19, p. 108-110, 1993.

HUMENHUK, $\mathrm{H}$. O direito à saúde no Brasil e a teoria dos direitos fundamentais . Jus Navigandi, Teresina, v.8, n. 227, 20 fev. 2004. Disponível em: <http://jus2.uol.com.br/doutrina/texto.asp?id=4839>. Acesso em: 20 out. 2009.

INSTITUTO BRASILEIRO DE GEOGRAFIA E ESTATÍSTICA. Rendimento Médio Real. Disponível em: <http://www.ibge.gov.br/mtexto/pmecrendi.htm>. Acesso em: 05 jul 2010.

KOTTOW, M. H. Comentários sobre bioética vulnerabilidade e proteção. In: GARRAFA, V.; PESSINI, L. Bioética: poder e injustiça. São Paulo: Loyola, 2003. p. 71-78.

KREISCHER, E. D. et al. Os direitos do paciente segundo o posicionamento de médicos e enfermeiros: pesquisa exploratória. Revista Brasileira de Enfermagem, Brasília, v. 49, p. 625-638, 1996.

LE COADIC, Y. F. A ciência da informação. Brasília, DF: Briquet de Lemos, 2004. $124 \mathrm{p}$.

LEMAIRE, J. F.; IMBERT, J. L. La responsabilité médicale. Paris: Presses Universitaires de France, 1985.

LE ROY, L. N. A internet na aprendizagem: aplicação do correio eletrônico em atividade pedagógica para alunos do ensino fundamental. 1997. 110 f. Dissertação (Mestrado em Educação) - Faculdade de Educação, Universidade de Brasília, Brasília, DF, 1997.

LIMA, R. C. G. S. et al. A construção do direito à saúde na Itália e no Brasil na perspectiva da bioética cotidiana. Saúde e Sociedade, São Paulo, v. 18, n. 1, p.118130, 2009.

LOPES, J. R. L. Direitos humanos e tratamento igualitário: questões de impunidade, dignidade e liberdade. Revista Brasileira de Ciências Sociais, São Paulo, v.15, n.42, p.77-100, 2000. 
MARIN, H. F.; MASSAD, E. AZEVEDO NETO, R. S. Prontuário eletrônico do paciente: definições e conceitos. In: MASSAD, E.; MARIN, H. F.; AZEVEDO NETO, R. S. (Ed.). O prontuário eletrônico do paciente na assistência, informação e conhecimento médico. Disponível em <http://www.sbis.org.br/site/arquivos/prontuario.pdf>. Acesso em: 15 jun. 2009.

MENDES, E. V. Uma agenda para a saúde. 2. ed. São Paulo: Hucitec, 1999. 300 p.

MENICUCCI, T. M. G. O Sistema único de saúde, 20 anos: balanço e perspectivas. Cadernos de Saúde Pública, Rio de Janeiro, v. 25, n. 7, p. 1620-1625, jul. 2009.

MINAYO, M. C. O desafio do conhecimento: pesquisa qualitativa em saúde. São Paulo: HUCITEC, 2008. 407 p.

MIRANDA, E. S. et al. Disponibilidade no setor público e preços no setor privado: um perfil de medicamentos genéricos em diferentes regiões do Brasil. Cadernos de Saúde Pública, Rio de Janeiro, v. 25, n.10, p. 2147-2158, 2009. Disponível em: <http://www.scielo.br/pdf/csp/v25n10/06.pdf>. Acesso em: 25 Mar. 2010.

MONTE, F. Q. A ética na prática médica. Bioética, Brasília, v. 10, n. 2, p.31-46, 2002.

MUSSEN, P. H. et al. Desenvolvimento e personalidade da criança. São Paulo: Harbra, 1988. 553 p.

PAIM, J. S. As políticas de saúde e a conjuntura atual. Saúde em Debate, Rio de Janeiro, n. 15/16, p. 8-15, 1984.

PEPE, V. L. E.; CASTRO, C. G. S. O. A interação entre prescritores, dispensadores e pacientes: informação compartilhada como possível benefício terapêutico. Cadernos de Saúde Pública, Rio de Janeiro, v. 16, n. 3, p. 815-822, 2000.

PEPE, V. L. E.; TRAVASSOS, C. M. A prescrição médica. Rio de Janeiro: Instituto de Medicina Social, UERJ, 1995.

PEREIRA FILHO, A.; CARNEIRO, L. F.; MACHADO, M. L. R. (Coord.). Manual de diretoria clínica. São Paulo: Conselho Regional de Medicina do Estado de São Paulo, 2000. 81p. 
PINSKY, J.; PINSKY, C. B. (Org.). História da Cidadania. São Paulo: Contexto, 2003. $591 \mathrm{p}$.

PIOVESAN. F. Direitos humanos e o direito constitucional internacional. São Paulo: Saraiva, 2007.

POLIT, D. F.; BECK, C. T.; HUNGLER, B. P. Fundamentos de pesquisa em enfermagem, 5. ed. Porto Alegre: Artmed, 2004. 487p.

QUENTAL, C. et al. Medicamentos genéricos no Brasil: impactos das políticas públicas sobre a indústria nacional. Ciência e Saúde Coletiva, Rio de Janeiro, vol.13, supl., p. 619-628, 2008. Disponível em: <http://www.scielo.br/pdf/csc/v13s0/a11v13s0.pdf>. Acesso em: 12 jan. 2010.

RAEFFRAY, A. P. O. Direito da saúde: de acordo com a constituição federal. São Paulo: Quartier Latin do Brasil, 2005.

ROCHA, J. C. S. Direito da saúde. São Paulo: LTr, 1999.

ROUSSEAU, J. J. O contrato social. Trad. Antônio de Pádua Danesi. São Paulo: Martins Fontes, 2001.

ROTTA, C. S. G. et al. Diretrizes: metas e medidas para obtenção da qualidade do prontuário. Revista de Administração em Saúde, São Paulo, v. 5, n. 20, p. 17-22, 2003.

SANO, P.Y. et al. Avaliação do nível de compreensão da prescrição pediátrica. Jornal de Pediatria, Porto Alegre, v. 78, n. 2, p. 140-145, 2002.

SANTOS, N. R. A reforma sanitária e o sistema único de saúde: tendências e desafios após 20 anos. Saúde em Debate, Rio de Janeiro, v. 33, n. 81, p. 13-26, jan./abr. 2009.

SÃO PAULO (Estado). Lei estadual no 10.241, de 17 de março de 1999. Dispõe sobre os direitos dos usuários dos serviços e das ações de saúde no Estado e dá outras providências. Disponível em: <http://www.pge.sp.gov.br/centrodeestudos/bibliotecavirtual/dh/volume\%20i/saudelei 10241.htm>. Acesso em: 5 jul. 2009. 
SARLET, I. W. A eficácia dos direitos fundamentais. Porto Alegre: Livraria do Advogado, 1998. 392 p.

SAUNDERS C.M.; BAUM, M.; HOUGHTON, J. Consent, research and the doctorpatient relationship. In: GILLON, R. (ed.). Principles of health care ethics. London : John Wiley \& Sons, 1994, p. 457-70.

SCHERMERHORN, J. R.; HUNT, J. G.; OSBORN, R. N. Fundamentos do comportamento organizacional. 2. ed. Porto Alegre: Bookman, 2005. 328 p.

SILVA, J. A. Curso de direito constitucional positivo. São Paulo: Malheiros Editores, 2005. 921p.

SILVA, S. F. Sistema único de saúde 20 anos: avanços e dilemas de um processo em construção. Saúde em Debate, Rio de Janeiro, v. 33, n. 81, p. 38-46, jan./abr. 2009.

SOAR FILHO, E. J. A interação médico-cliente. Revista da Associação Médica Brasileira, São Paulo, v. 44, n. 1, p. 35-42, 1998.

SPIRI, W. C.; BERTI, H. W.; PEREIRA, M. L. D. Os princípios bioéticos e os direitos dos usuários de serviços de saúde. Mundo da Saúde, São Paulo, v. 30 n. 3, p. 448454, 2006.

TRIVIÑOS, A. N. S. Introdução à pesquisa em ciências sociais. São Paulo: Atlas, 1987. $175 \mathrm{p}$.

VALENTIM, M. L. P. Informação e conhecimento em organizações complexas. In: VALENTIN, M. (Org.). Gestão da informação e do conhecimento no âmbito da ciência da informação. São Paulo: Polis, 2008. p. 11-25.

VELOSO, R. C.; SPINDOLA, T. A percepção do cliente hospitalizado acerca de seus direitos e deveres. Revista Enfermagem UERJ, Rio de Janeiro, v. 13, p. 38-43, 2005.

VIANA, A. L. D.; MACHADO, C. V. Proteção social em saúde: um balanço dos 20 anos do SUS. Physis, Rio de Janeiro, v.18, n. 4, p. 445-684, 2008. 
VON ZUBEN, N. A. Vulnerabilidade e decisão: tensão no pacto médico. 0 Mundo da Saúde, São Paulo, v. 30, n. 3, p. 441-447, jul./set. 2006.

WELLISCH, $H$. From information science to informatics: a terminological investigation. Journal of Librarianship, London, v. 4, n. 3, p. 157-187, 1972.

WORLD HEALTH ORGANIZATION. Essential medicines. Disponível em: $<$ http://www.who.int/medicines/services/essmedicines_def/en/index.html> . Acesso em: 20 Mar. 2010.

ZANINI, A. C.; PAULO, L. G. Expectativas, dúvidas e fantasias da consulta médica. In: PAULO, L. G.; ZANINI, A. C. Compliance: sobre o encontro paciente-médico. São Roque: IPEX, 1997, cap.1, p. 1-8. 


\section{APÊNDICES}




\section{APÊNDICE A - Termo de consentimento livre e esclarecido \\ Pesquisa:}

\section{Direito à informação em saúde: análise do conhecimento do paciente acerca de seus direitos}

Pesquisadora: Renata Antunes de Figueiredo Leite

Orientadora: Profa. Dra. Carla Aparecida Arena Ventura

Meu nome é Renata Antunes de Figueiredo Leite, sou aluna do Mestrado em Enfermagem Psiquiátrica, da Escola de Enfermagem de Ribeirão Preto - USP, onde estou desenvolvendo essa pesquisa. Gostaria de convidá-lo(a) a participar deste estudo, que tem como objetivo: identificar 0 conhecimento de usuários do SUS sobre os direitos à informação dos pacientes estabelecidos na Lei estadual 10.241/1999, que é uma lei que trata dos direitos dos pacientes. Explicando melhor, gostaria de saber se os usuários do SUS são informados sobre assuntos relacionados à sua saúde, ou seja, que doença ele tem, que remédio deve tomar, sobre o tratamento a ser realizado, explicações sobre receitas médicas, etc. Esclarecemos, que participar dessa pesquisa trará benefícios diretos a você, pois você poderá conhecer seus direitos enquanto paciente. Assim, sua participação irá contribuir para enriquecer esse trabalho, pois os resultados poderão ser divulgados por meio de palestras e/ou panfletos informativos sobre os direitos do paciente na Unidade Básica de Saúde e contribuir para que os serviços e 0 atendimento melhorem, pois ao saber de nossos direitos podemos exigir mais dos profissionais ao tratarem de nossa saúde.

Caso você concorde em participar, farei a você algumas perguntas sobre esse assunto, na Unidade Básica de Saúde, numa sala individual, enquanto você aguarda ou após a sua consulta se preferir. Essa conversa será gravada se você assim permitir. É importante a gravação para que nenhum detalhe passe despercebido, e para que mais tarde eu não faça nenhuma confusão, já que conversei com outras pessoas. Nossa conversa não durará mais que 30 minutos e será feita em uma sala reservada para que você responda tranquilamente. Tudo o que você disser será utilizado somente para essa pesquisa e será mantido em segredo. Outras pessoas não ouvirão essa gravação. Seu nome verdadeiro não aparecerá e se você não quiser responder alguma pergunta, não terá qualquer problema. Mesmo que você concorde em conversar comigo, se durante a entrevista eu lhe fizer alguma pergunta que você não queira responder ou se quiser desistir, é só me dizer, que você será atendido pelo serviço de saúde da mesma maneira.

Quando terminarmos esta pesquisa, o resultado final poderá ser divulgado em revistas e/ou apresentado em encontros científicos. Sua participação é completamente voluntária e não haverá custo, nem remuneração por sua participação.

Caso tenha alguma dúvida, você poderá nos perguntar ou entrar em contato conosco através do endereço Escola de Enfermagem de Ribeirão Preto-USP, Avenida Bandeirantes, 3900, ou pelo telefone (16) 36023422 - Prof ${ }^{\mathrm{a}}$ Carla A. Arena Ventura

Diante de tudo que foi dito e esclarecido pela pesquisadora, eu concordo em participar voluntariamente dessa pesquisa, recebendo uma cópia desse termo, para possível contato se for necessário.

Nome do Participante.

Assinatura do Participante

Assinatura da Pesquisadora (Renata A. F. Leite)

Assinatura da Orientadora (Carla A. A. Ventura).

Ribeirão Preto, de de 2010. 
APÊNDICE B - Roteiro para a realização das entrevistas semi-estruturadas

1- Dados sócio-demográficos:

- Sexo:

- Estado Civil:

- Idade:

- Escolaridade:

- Profissão:

- Renda:

- menos de 1 salário mínimo

๑ 1 a 3 salários mínimos

3 a 5 salários mínimos

๑ 5 a 7 salários mínimos

- 7 ou mais salários mínimos

- Quantas vezes você já utilizou este serviço de saúde?

- 1 a 3 vezes

$\square 4$ a 6 vezes

$\square$ mais de 6 vezes

2. Quais informações você normalmente recebe dos profissionais de saúde ao usar um serviço público de saúde? [sobre diagnóstico, sobre exames (o porquê, e finalidade), sobre as ações de cuidado dos profissionais, sobre os riscos/benefícios do seu tratamento, duração do tratamento, efeitos colaterais dos medicamentos ou anestesia]

3. Durante a consulta, os profissionais de saúde perguntaram se você consentiria ou recusaria o tratamento ou algum procedimento realizado? (Em caso positivo, você achou esta pergunta importante? Em caso negativo, por que você acha que não foi feita esta pergunta a você?) 
4. Você sabe se pode ter acesso ao seu prontuário médico? Você já teve este acesso?

5. As receitas prescritas a você são normalmente fáceis de ler? Os medicamentos são genéricos?

6. Como você se sente quando recebe informações sobre o seu estado de saúde, sobre o seu tratamento, sobre suas possibilidades de escolha relacionadas a este tratamento? 
ANEXOS

ב-2 


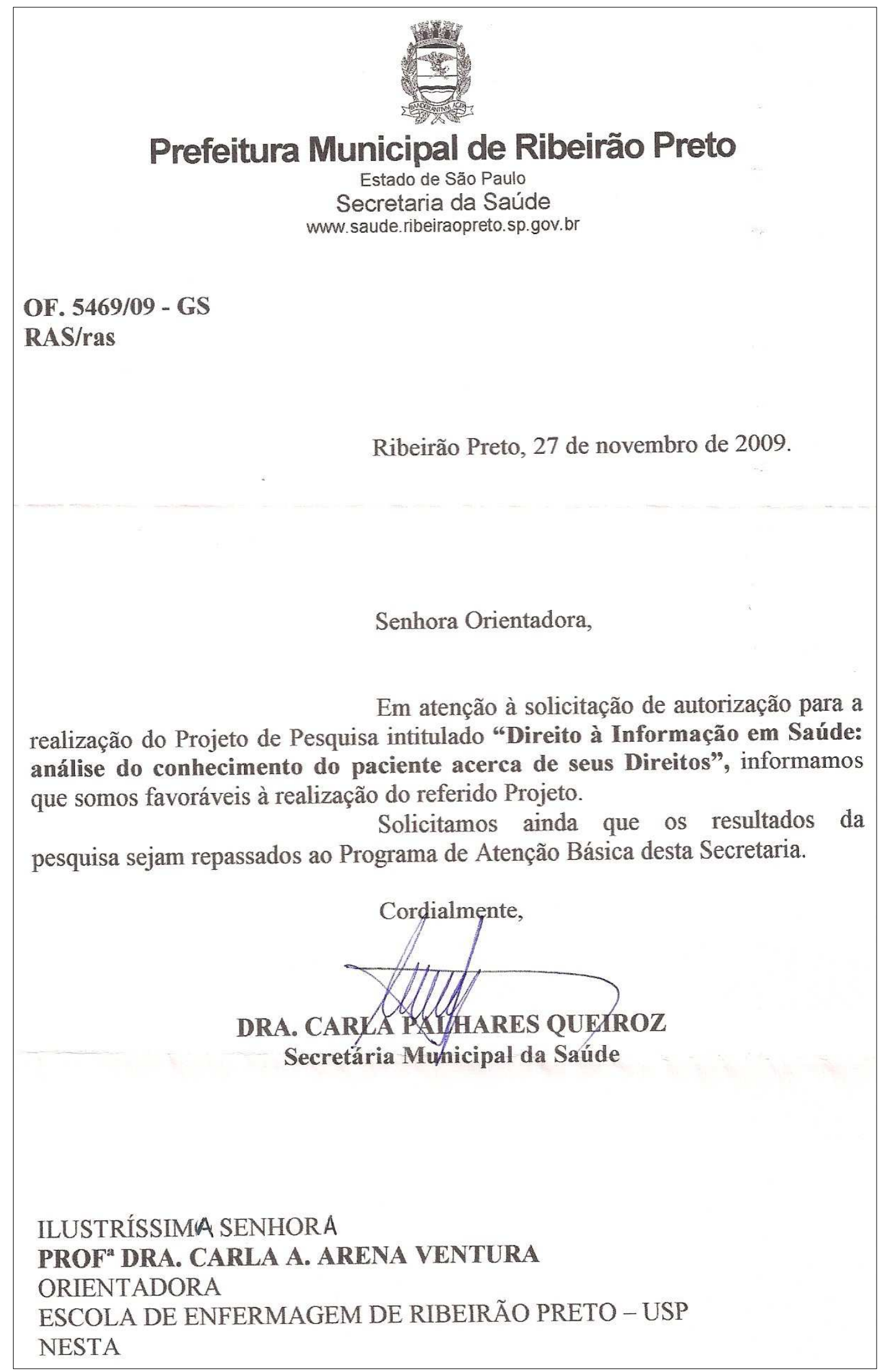


ANEXO B - Autorização - Comitê de Ética e Pesquisa da EERP/USP

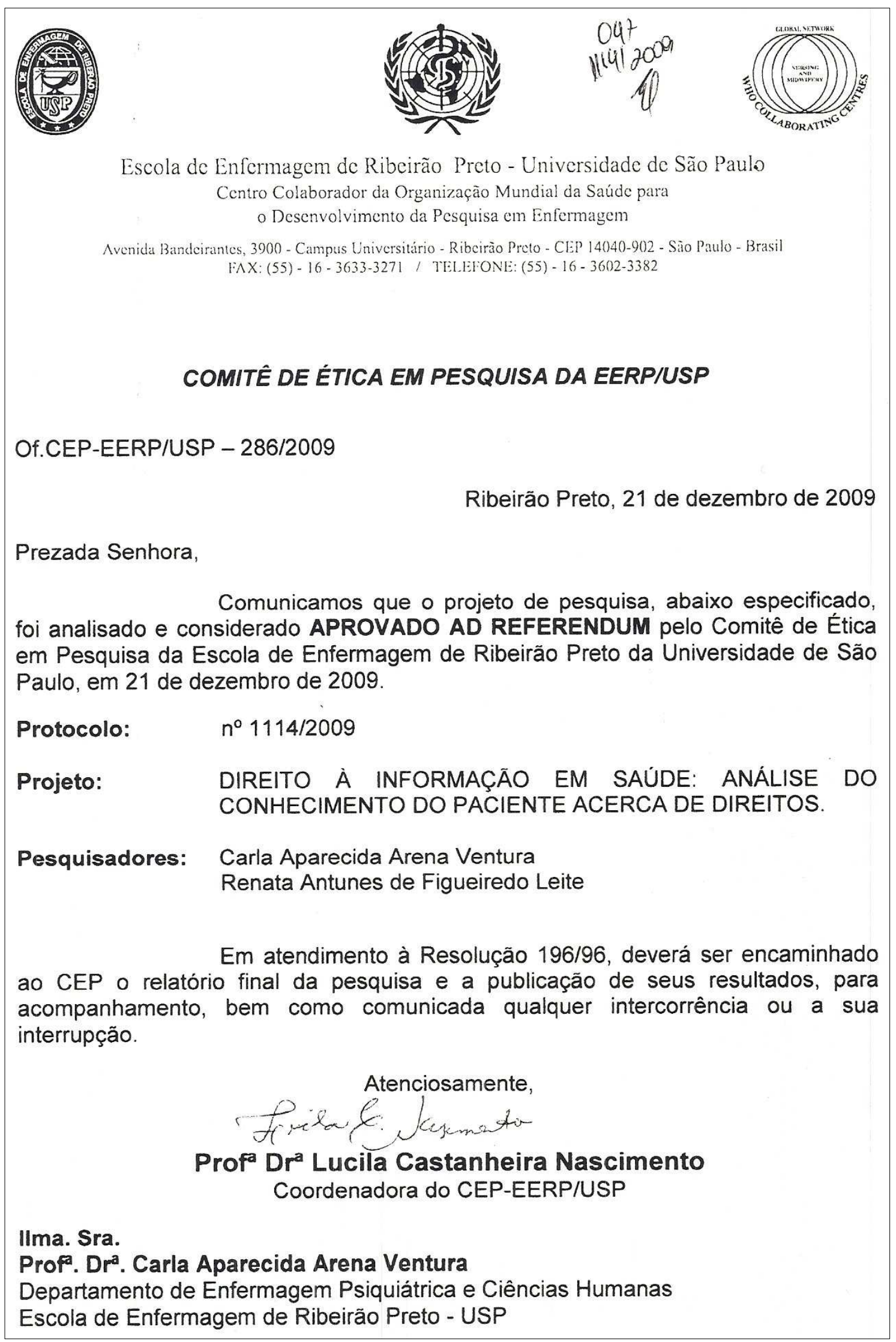

